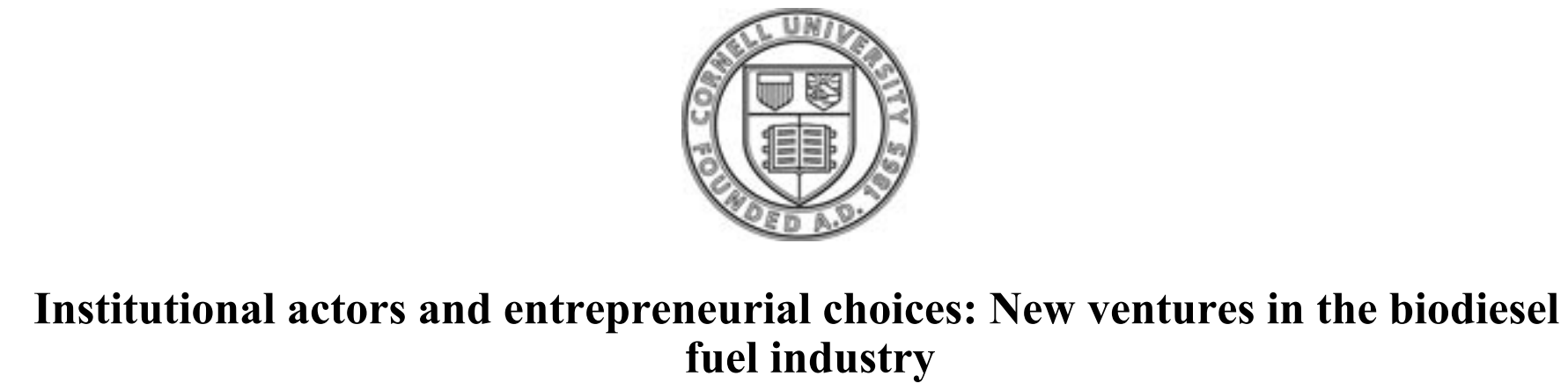

by Shon Russell Hiatt

This thesis/dissertation document has been electronically approved by the following individuals:

Tolbert,Pamela S (Chairperson)

Wells,Martin Timothy (Minor Member)

Sine,Wesley (Minor Member) 


\title{
INSTITUTIONAL ACTORS AND ENTREPRENEURIAL CHOICES: NEW VENTURES IN THE BIODIESEL FUEL INDUSTRY
}

\author{
A Dissertation \\ Presented to the Faculty of the Graduate School \\ of Cornell University \\ In Partial Fulfillment of the Requirements for the Degree of \\ Doctor of Philosophy
}

by

Shon Russell Hiatt

August 2010 
(C) 2010 Shon Russell Hiatt 


\title{
INSTITUTIONAL ACTORS AND ENTREPRENEURIAL CHOICES: NEW VENTURES IN THE BIODIESEL FUEL INDUSTRY
}

\author{
Shon Russell Hiatt, Ph.D. \\ Cornell University 2010
}

Entrepreneurs face a host of potential choices in creating new firms, yet little is known about how multiple institutional actors promoting different practices and technologies can affect entrepreneurial decision-making, especially at the beginning of new sectors and technological lifecycles. Using historical data and quantitative analyses of U.S. biodiesel producer foundings, technological innovation and diversity, I highlight the impact of competing institutional actors (agriculture trade associations) on entrepreneurial decision-making and activity. I posit that greater competition or heterogeneity of trade associations promoting various technologies will result in higher rates of biodiesel foundings as well as technological variation and innovation. I also analyze the moderating influences of competing institutional actors (Sierra Club/environmental lobby actors) and entrepreneurial network relations (captured by de novo and de alio entrants) on trade association effectiveness. In a final analysis, I explore the moderating influence of institutional actor size on actor heterogeneity. The dissertation contributes to the growing nexus of institutions and entrepreneurship research as well as to the research on technology entrepreneurship. 


\section{BIOGRAPHICAL SKETCH}

Shon Russell Hiatt was born and raised in northern Idaho, the eldest of seven children to Carlton Russell and Sulet Smith Hiatt. Having spent much of his free time working on his grandparents’ dairy farm, he developed an interest in agri-business. He received a B.A. and M.P.A. from Brigham Young University, during which period he interrupted his schooling to serve a two-year mission for The Church of Jesus Christ of Latter-day Saints in Chile. He later earned an M.S. in organizational behavior from Cornell University. Shon's research interests explore issues related to institutional change, innovation, industry and technology evolution, and strategy in a diverse set of economic contexts ranging from the energy sector to emerging economies. Upon defending his dissertation in June 2010, Shon took a job as an assistant professor at Harvard Business School. 
This dissertation is dedicated to my beautiful and inspirational wife, Elizabeth, whose support, love, patience, and faith in me made this possible. I also dedicate this dissertation to our four stalwart boys, Joseph, Charles, Robert, and Michael. 


\section{ACKNOWLEDGEMENTS}

Special appreciation goes to my committee members, Pamela Tolbert, Wesley Sine, Martin Wells for their encouragement and support in this project. I also would like to thank Brandon Lee, Sangchan Park, Evan Polman, Brian Rubineau, Diane Burton, Chad Carlos, Jack Goncalo, Olga Khessina, Marya Besharov, Tim Pollock, Matthew Kraatz, and Elizabeth Hiatt for their insightful comments. I acknowledge support for this project from the J. Thomas Clark Professorship in Entrepreneurship, the Johnson Graduate School of Management, and the Cornell School of Industrial and Labor Relations. This research was funded in part by the Ewing Marion Kauffman Foundation. The contents of this publication are solely the responsibility of me. 


\section{TABLE OF CONTENTS}

Biographical Sketch iii

Dedication $\quad$ iv

Acknowledgements $\quad$ V

List of Tables vii

$\begin{array}{ll}\text { Chapter } 1 & 1\end{array}$

Theory and Research Overview

$\begin{array}{lc}\text { Chapter } 2 & 8\end{array}$

The Effect of Competing Institutional Actors and Network Relations

on Institutional Actor Influence

Chapter 3

The Effect of Institutional Actor Competition on Entrepreneurial

Activity in the U.S. Biodiesel Industry 


\section{LIST OF TABLES}

Table 1

Descriptive and Bivariate Correlations

Table 2

Competing Risks Regression of Agriculture-Intensive Related Technologies

Table 3

Competing Risks Regression of Non-Intensive Agriculture Related

Technologies

Table 4

Competing Risks Regression of Agriculture-Intensive Related Biodiesel

Technologies-De Novo

Table 5

Competing Risks Regression of Non-Intensive Agriculture Related Biodiesel

Technologies—De Novo

Table 6

Competing Risks Regression of Agriculture-Intensive Related Biodiesel

Technologies-De Alio

Table 7

Competing Risks Regression of Non-Intensive Agriculture Related Biodiesel

Technologies-De Alio

Table 8

Descriptive Statistics and Bivariate Correlations

Table 9

Piecewise Exponential Model of Biodiesel Founding Events by State-Year 
Table 10

Piecewise Exponential Model of Recombinatorial-Technology Biodiesel Founding Events by State-Year

Table 11

General Least Squares Analysis of Technological Diversity of Biodiesel Foundings by State-Year 


\section{CHAPTER 1}

\section{THEORY AND RESEARCH OVERVIEW}

I address two major theoretical and empirical questions in this dissertation: At the beginning of new technological sectors, what environmental factors affect entrepreneurial decision-making? And, in such contexts, what elements impact newventure innovation? Regarding the first question, past research exploring the choices of potential or current entrepreneurs usually cast them as highly rational beings that develop or adopt technologies and organizational forms based on available information such as technological efficiency, lifecycle age, availability and cost of resources, market demand, etc. (Schumpeter, 1934; Simon, 1947; Kirzner, 1973; Hannan and Freeman, 1977; Blau, 1987; Dunne, Roberts, and Larry, 1988; Evans and Jovanovic, 1989; Tushman and Anderson, 1986; Evans, 1989; Hayek, 1949).

While these studies provide a foundation to understand how entrepreneurs make decisions in established sectors, at the beginning of new industries, information is often scarce and technologies are unpredictable. In such environments, I propose that powerful institutional actors can affect entrepreneurial decision-making by creating social structures that shape potential and current entrepreneurs' choices. By promulgating prescriptions that promote new practices and technologies and by furnishing information and demonstrations that can enlighten cognitive understandings, powerful actors can change the logics—values, beliefs, and understandings — -held by individuals (Sine, Haveman, and Tobert, 2005; Hargrave and Van de Ven, 2006). Consequently, institutional actors can reduce perceived risks surrounding certain technologies and organizational forms and encourage entrepreneurial action and adoption. 
Concerning the second question, the literature on technological innovation has traditionally overlooked how powerful actors in the environment can foster technological innovation, and instead has generally treated the emergence of new technologies as isolated exogenous occurrences (Schumpeter, 1934; Tushman and Anderson, 1986). While a few scholars have begun to acknowledge the role of powerful actors in creating and sponsoring new kinds of technologies and practices (Garud, Jain, and Kumaraswamy, 2002; Hargrave and Van de Ven, 2006; Sine and Lee, 2009; Hiatt, Sine, and Tolbert, 2009), they have largely focused on one kind of actor, promoting a single practice. We know very little about how competing actors promoting different practices can affect the emergence of new technologies. I address this void by analyzing how competition among institutional actors can foster the development of new technologies as well as technological diversity.

Empirically, I measure new-venture foundings and technological choice, diversity, and innovation in the nascent U.S. biodiesel sector. This is an ideal context in which to address these questions as the industry largely arose from the actions of powerful agriculture trade associations, such as the American Soybean Association and National Cottonseed Producers Association, which promoted and sponsored varying production technologies. The institutionalization projects they engaged in to create new markets in which to sell their farm products as well as the ensuing competition among them had remarkable effects on the growth and development of the sector. In the following paragraphs, I will highlight some of the findings from the project.

In Chapter 2, I explore how institutional actors (i.e. agricultures trade associations) affect entrepreneurial decision-making at the beginning of new markets and the factors that can moderate their influence. The results showed that among several competing trade associations, greater strength or membership size of a specific 
trade association promoting technological prescriptions and understandings had a positive impact on the rate of biodiesel firms adopting that particular technology. Additionally, competition between trade associations and environmental lobby actors (Sierra Club members) who opposed certain biodiesel production technologies in a state created a blending as well as a magnifying effect on the influence of the trade association. When the promoted technologies were incongruent with logics promoted by Sierra Club members, a greater presence of Sierra Club actors did not negatively affect biodiesel foundings, but entrepreneurs developed new technologies that were in harmony with the values and interests of the Sierra Club instead of the technology promoted by the trade association. In contrast, when a promoted technology was in harmony with the logics of the Sierra Club, the presence of Sierra Club actors had a magnifying effect on the influence of the trade association, wherein more entrepreneurs founded biodiesel ventures that implemented the promoted technology.

In the second part of Chapter 2, I measure how entrepreneurial network relations can moderate the influence of institutional actors. Empirically, I analyze how de novo versus de alio ventures react to the actions of trade associations and the Sierra Club. I found that de novo entrants were more susceptible to the promoted prescriptions and scripts of institutional actors (both trade associations and Sierra Club) than de alio entrants because they generally were more concerned about legitimacy and relied more upon resources in the local environment than de alio ventures. In sum, the results indicate that competing actors and network relations can have significant moderating effects on the influence of focal institutional actors and entrepreneurial decision-making. They also show that the development and adoption of new technologies occur in environments where actors compete for entrepreneurial attention. 
In Chapter 3, I continue my exploration into the effects of competition among institutional actors and analyze how the degree of competition, or organizational heterogeneity, among competing actors affects the decision of potential entrepreneurs to found a firm, impacts technological diversity, and influence the development of innovative recombinatorial technologies. I found that increased competition or heterogeneity among agriculture trade associations fostered biodiesel foundings by appealing to a broad variety of individual tastes and values. Moreover, the results indicated that trade association heterogeneity had a greater effect on new-venture foundings than sheer size or strength of the associations involved. In another analysis, I found that greater competition as measured by heterogeneity among trade associations had a positive effect on technological diversity and that the effect was greater than the impact of size or strength of the competing associations. As new ventures adopted a variety of promoted technologies, technological variation in a given state also increased.

In the second part of Chapter 3, I explore how greater competition among institutional actors affects entrepreneurial innovation. I find that by providing entrepreneurs with a wide repertoire of technologies, values, and ideas, greater competition among trade associations can lead to the development of innovative recombinatorial technologies. When there were many equal voices promoting various new technologies, entrepreneurs were more likely to create a technological process that combines two or more technologies. And, similar to previous findings, the impact of institutional actor competition on recombinatorial technologies was greater than the overall size effect of the actors. I also analyzed the interaction between institutional actor size and heterogeneity. The results indicated that greater overall size of competing trade associations moderately increased state technological diversity as well as the effect of trade association competition on entrepreneurs' decision to found 
a firm in a new sector and innovate. Thus, competition among institutional actors can be a significant factor behind entrepreneurial activity, innovation, and technological diversity at the beginning of new sectors. 


\section{REFERENCES}

Blau, D. M. 1987. A time-series analysis of self-employment in the United States. The Journal of Political Economy, 95(3): 445-467.

Dunne, T., Roberts, M. J., \& Larry, S. 1988. Patterns of firm entry and exit in U.S. manufacturing industries. Rand Journal of Economics, 19: 495-515.

Evans, C. R. \& Jovanovic, B. 1989. An Estimated Model of Entrepreneurial Choice under Liquidity Constraints. The Journal of Political Economy, 97(4): 808-828.

Evans, D. L. L. 1989. Some empirical aspects of entrepreneurship. American Economics Review, 79: 519-535.

Garud, R., \& Kumaraswamy, A. 1995.Technological and organizational designs for realizing economies of substitution. Strategic Management Journal, 16: 93-109.

Hannan, M. T. \& Freeman, J. 1977. The population ecology of organizations. American Journal of Sociology, 82: 929-964.

Hargrave, T. J. \& Van de Ven, A. H. 2006. A collective action model of institutional innovation. Academy of Management Review, 31(4): 864-888.

Hayek, F. A. 1949. The meaning of competition, Individualism and Economic Order: 92-106. London: Routledge \& Kegan Paul.

Hiatt, S. R., Sine, W. D., \& Tolbert, P. T. 2009. From Pabst to Pepsi: The deinstitutionalization of social practices and the creation of entrepreneurial opportunities. Administrative Science Quarterly, 54: 635-667. 
Kirzner, I. M. 1973. Competition and entrepreneurship. Chicago, IL: University of Chicago Press.

Schumpeter, J. A. 1934. Capitalism, Socialism, and Democracy. New York: Harper \& Row.

Sierra Club. 2000. Sierra Club Conservation Policies: Biomass Guidance. San Francisco, CA: Sierra Club.

Simon, H. A. 1947. Administrative Behavior. New York: Macmillan.

Sine, W. D., Haveman, H. A., \& Tolbert, P. S. 2005. Risky Business?

Entrepreneurship in the New Independent-Power Sector. Administrative Science

Quarterly, 50(2): 200-232.

Sine, W. D. \& Lee, B. H. 2009. Tilting at windmills? The environmental movement and the emergence of the U.S. wind energy sector. Administrative Science Quarterly, 54: 123-155.

Tushman, M. L. \& Anderson, P. 1986. Technological Discontinuities and Organizational Environments. Administrative Science Quarterly, 31(3): 439-465. 


\section{CHAPTER 2}

\section{THE EFFECT OF COMPETING INSTITUTIONAL ACTORS AND NETWORK RELATIONS ON INSTIUTTIONAL ACTOR INFLUENCE}

\section{Introduction}

Over the last decade, organizational scholars have intensified their focus on the role of powerful institutional actors such as professional associations or social movements in fostering entrepreneurial activities in new sectors (Rao, Morrill, and Zald, 2000; Swaminathan and Wade, 2001; Schneiberg, King, and Smith, 2008; Weber, Heinze, and DeSoucey, 2008; Hiatt, Sine, and Tolbert, 2009). ${ }^{1}$ Often termed institutional entrepreneurs (DiMaggio, 1988; Maguire, Hardy, and Lawrence, 2004; Greenwood and Suddaby, 2006), these agents consciously seek to alter existing institutional arrangements that shape organizations, by legitimating products and forms of organizations within a field and lobbying for regulatory changes that provide resources or enable/forbid certain activities. In such way, they can create opportunities for entrepreneurs to found new organizations such as bureaucratic thrifts, wind-power generation plants, and organic certifying agencies (Haveman, Rao, and Paruchuri, 2007; Sine and Lee, 2009; Lee, 2009).

While such studies have enhanced our understanding of how powerful actors can facilitate opportunity creation and exploitation, much of the literature on institutions and entrepreneurship focuses on one institutional actor promoting a single

\footnotetext{
${ }^{1}$ While there are many ways in which scholars have defined institutions and institutional actors, in this paper I define institutions as organizational forms, components, structures, or technologies that have become taken-for-granted as efficacious and necessary (Meyer and Rowan, 1977). I define institutional actors as individual or collective actors that promote organizational arrangements or structures in an effort to institutionalize them (DiMaggio, 1988; Tolbert and Zucker, 1996).
} 
practice and assumes that the activities of such actor affect all entrepreneurs equally. Yet, there are often multiple actors, competing with each other, trying to influence entrepreneurs simultaneously. This is particularly salient at the beginning of new sectors and technological lifecycles where multiple practices and technologies are often developed and promoted by varying actors (Tushman and Anderson, 1986; Hargrave and Van de Ven, 2006). What determines new ventures' responses to the potential influence of competing institutional actors?

Additionally, entrepreneurs are likely to be immersed in a variety of relational contexts that may moderate the influence of institutional actors on entrepreneurial decision-making depending on the particular groups or individuals they are connected to (Emirbayer and Mische, 1998). For instance, Rao, Davis, and Ward (2000) showed that publicly traded companies with strong ties to other companies in the NASDAQ were less likely to view the NYSE as a more desirable location and were more inclined to stay in the NASDAQ. In such cases where multiple institutional actors compete and entrepreneurs are embedded in particular relational networks, what are the conditions that lead one actor or the other to have greater influence, and how do these influences interact?

I address these questions by looking at entrepreneurial activities in the U.S. biodiesel industry, a new sector where technologies are still very much in flux and where a variety of institutional actors are actively seeking to influence business entrepreneurs’ definitions of the "right” technology. Empirically, I explore how a variety of agriculture trade associations promoting specific biodiesel technologies related to their industry and an environmental lobbying group can affect the technological choices of new entrants in this sector from 1990 through 2008. Additionally I analyze how relational networks between new ventures and organizations in other sectors can moderate institutional actor influence. I propose 
ways in which incongruent logics of competing institutional actors and network relations can magnify, dampen, and blend the influence of focal institutional actors.

\section{Biodiesel industry}

The biodiesel sector presents an ideal context in which to study moderating effects of competing institutional actors and relational networks on the ability of institutional actors to change cognitive and normative understandings. Biodiesel is fuel derived from a variety of organic sources for use in compression-ignition (diesel) engines. Typical feedstock oil includes soybean and canola oils, beef and pork tallow, and fryer oil from restaurants. Once oil is extruded from oil-seed plants, rendered from animal carcasses, or siphoned from restaurant grease traps, it undergoes a transesterification process in a biodiesel production facility where, through varying technologies individualized for each kind of extracted oil, glycerol is removed from triacylglycerol (triglyceride) leaving alkyl esters, resulting in a liquid compound that has properties similar to petroleum distillates used to power diesel engines. The type of fats and oils used as feedstocks determines the type of chemical and mechanical process or technological design (Van Gerpen, Pruszko, Clements, Shanks, and Knothe, 2006). Thus, the technological design used to process, for example, soybeans is different from that used to process, for example, poultry fats. ${ }^{2}$

The technology to make biodiesel came about through a series of improvements in soap-making technology and perfected in universities across the nation in response to the energy crises of the 1970s. A number of state-based agricultural trade associations found out about the research being conducted by

\footnotetext{
${ }^{2}$ There is a moderately high retooling cost associated with changing production feedstock technologies. On average, biodiesel producers that had the resources to change technological designs in order to utilize other kinds of raw materials were forced to idle their plants for about a year. Thus, entrepreneurs are highly motivated to pick the best production design from the start.
} 
academics and began sponsoring their work in order to develop viable technological processes that could convert their farm products into biodiesel. Then, using their chapter members and resources, they began promoting such technologies. For example, the American Soybean Association promoted feedstock technologies that utilized soybean oil as a raw material while the U.S. Canola Association endorsed technologies that used canola oil. The National Renderers Association drew attention to technologies that utilized animal tallow while the National Corn Growers Association advocated technologies that employed corn oil as a biodiesel raw material.

Thus, while all the agriculture associations in this study shared a common concern with the biodiesel sector, they promoted varying production technologies depending on the industry members they represented. Because all the technologies were very new, entrepreneurs could not simply conduct a cost-benefit analysis of which technological production process they should adopt. Thus, agriculture trade associations promoting the "best” technology likely had a large influence on the decision of entrepreneurs to found a firm and to adopt or develop a production process.

Yet, as the budding sector started to take form, other powerful actors already present in the institutional environment opposed most of the promoted production technologies mentioned above. Environmental movement organizations such as Sierra Club and to a lesser extent Friends of the Earth and Greenpeace attacked what they defined as intensive agriculture practices to produce the raw materials that were transformed into biodiesel and engaged their members to frame, label, and sponsor research claiming such production technologies as unsustainable and wrong. As they sought to discredit certain technologies through member mobilization, they likely had an influence in shaping the values and understandings held in the institutional environment, and in turn, affected entrepreneurial decision-making. 


\section{Institutional Actors and Technological Choice}

Institutional actors can have a profound influence on the technological choice of entrepreneurs. At the beginning technological lifecycles the complexity of and uncertainty about new technologies, the lack of consensus about the technology's ultimate form or function, and the high amounts of raw data as well as individual processing capabilities needed to understand or use the technology can make it difficult for entrepreneurs to adopt a particular technology (Weick, 1990). In such environments, the presence of institutional actors who can provide information and prescriptions may strongly shape the propensity of individuals to found a firm and adopt a particular technology (Suchman, 1995).

Powerful institutional actors can provide information that can change the cognitive value and symbolic meaning of technologies into artifacts that entrepreneurs can comprehend and assess. As Pinch and Bijker (1984) noted, technology is socially constructed and is subject to situational factors and interpretive processes. Thus, by “devising ontological frameworks, proposing distinctions, creating typifications, and fabricating principles” (Scott and Backman, 1990: 29), institutional actors can help new technologies become "part of the objective, structural properties" of the institutional environment (Orlikowski, 1992: 406). Another way actors can change cognitive beliefs is by conducting repeated demonstrations of the new practice or technology. These evaluation routines provide individuals or organizations with tacit or inarticulate knowledge of the technology thereby shaping their understanding and perception. For example, Garud and Rappa (1994) found that by conducting multiple demonstrations and tests of cochlear implant technology, technology developers were able to alter the FDA and the public's belief of the implants safety and usefulness.

Institutional actors can also shape the propensity of entrepreneurs to adopt an uncertain technology by promoting certain values or prescriptions that define what is 
appropriate. Sometimes, this entails promoting a culture or identity that is conducive for the adoption of a particular technology. For example, in the grass-fed meat and dairy sector, activists mobilized broad cultural codes to create a collective producer identity and a market in which such products could be produced and sold. The resulting identities facilitated the exchange between producers and consumers and motivated entrepreneurs to enter the new market and adopt the unique agriculture technology (Weber, Heinze, and DeSoucey, 2008). Institutional actors can also shape normative prescriptions by setting standards (Hargrave and Van de Ven, 2006). For example, Lee (2009) found that by starting organic standards-based certifying organizations, organic food activists were able to convince existing and new farmers to adopt similar growing technologies. More often, however, setting normative prescriptions often entails actors propagating principles that explicitly define what is right and wrong, by arguing that the technology is scientifically the best practice or that it is in the best interest of the adopter or humanity (Scott, 2008). For instance, in their study of the emergent wind power sector, Sine and Lee (2009) found that by using scientific evidence to promote the environmentally friendly benefits of wind power, environmental activists had a positive impact on the founding of wind power producers.

In the case of the biodiesel industry, state agriculture trade association chapters mobilized their members to diffuse information about the biodiesel technology that was specific to their agricultural product. They organized agriculture conferences and attended county fairs, and other public venues to discuss and demonstrate the new technology. Association members bought trucks and tractors, filled them up with biodiesel made from their particular agricultural product, and drove them hundreds of miles around the state in an effort to increase confidence in its viability. Many 
entrepreneurs said that these demonstrations were one of the main reasons that they adopted the technology and founded a biodiesel company.

Agriculture trade associations also argued that their specific technology was scientifically tested and represented the "best practice.” They sponsored research in universities and then accompanied scientists to public venues to testify of the technologies' effectiveness and appropriateness. Trade associations also worked to convince potential entrepreneurs that adopting the specific technology was in their best interest. For example, state soybean associations highlighted to potential entrepreneurs that the adoption of soybean technology to produce "soydiesel” (a term they coined) would be more accepted by farmers and other agriculture professionals in the soybean business - a group that constituted the majority of agriculture consumers in many states. Agriculture trade association members also touted the benefits of their technology for helping the country wean itself off of imported oil becoming energy independent and self-reliant.

In sum, I argue that given the uncertainty surrounding new technologies at the beginning of new markets and technological lifecycles, the presence of key actors diffusing information about particular technologies and promoting normative prescriptions will have a positive effect on the founding of new ventures implementing the particular technology that an actor promotes.

Hypothesis 1: A greater number of trade association members in a state promoting a specific technology will have a positive effect on the founding of biodiesel ventures implementing that technology.

\section{Competing Institutional Actors}

Nevertheless, much of the literature on institutions and entrepreneurship has focused on the one kind of institutional actor (Weber, Heinz ,and DeSoucey, 2008; 
Sine and Lee, 2009; Hiatt, Sine and Tolbert, 2009), and has failed to take into account other competing institutional actors, which often characterizes early periods of new technologies and sectors. There is little research that examines how competing institutional actors may influence the effectiveness of focal institutional actors in emerging sectors. Yet, the idea of multiple institutional actors has been partly acknowledged in the research that explores competing logics (Thornton, 2001, 2002). For example, Lounsbury (2007) explored how different mutual fund trustee and performance logics espoused in Boston and New York respectively led to variation between the two cities in how mutual funds established contracts with professional money management firms. Likewise, Marquis and Lounsbury (2007) analyzed two kinds of banking logics, local and national, on the kinds of banks that were founded in rural American communities. They found that local banking beliefs held in rural communities negatively impacted the communities' perception and acceptance of national bank entry into such areas. However, most of this work has been theoretical and empirical studies in the tradition have tended to act as if logics are compartmentalized and geographic specific.

This paper addresses this shortcoming by explicitly focusing on both the independent effects of actors who are promulgating particular logics as well as the potential interactive effects of these logics on entrepreneurial decision-making. To describe the interactive or moderating effects of competing actors, it may be useful to use an analogy of light. By interacting with various mediums, light can be magnified, dampened, or even blended to create different colors. Similarly, the influence of promoted normative prescriptions and cognitive understandings by focal institutional actors may be magnified, dampened, or blended by the promoted logics of competing entrepreneurs and/or by the relational networks of the entrepreneurs. 
Magnification refers to when promoted values or cognitive information have an amplified effect on the receiver in which the individual or organization quickly and wholeheartedly adopts those new viewpoints and values. This may occur when institutional actors promote normative prescriptions or cognitive understandings that are congruent with espoused beliefs, knowledge, and values, or when the promoted prescriptions and scripts are harmonious with other promoted logics in the institutional environment. This is exemplified in the promotion of insurance mutuals and dairy cooperatives. The Grange movement of the early $20^{\text {th }}$ century experienced greater success at promoting these new organizational forms in counties that were dominated by farmers, because their agriculture-empowerment prescriptions matched the farmers’ rural values and interests (Schneiberg, King, and Smith, 2008).

However, if promoted values or cognitions are incongruent with competing beliefs and values, two types of moderating effects may occur: dampening or blending. Dampening refers to when the promoted values or cognitive understandings have less of an influence in changing the cognitions and beliefs of individuals or organizations. In such cases, competing cultural values and interests overpower the focal institutional actor's attempts to change the environment. For example, the promotion of temperance and prohibition laws by the Woman's Christian Temperance Union (WCTU) had a lesser effect in areas high in German and Irish immigrants because the immigrants' culture of beer consumption had an overpowering effect on the acceptance of incongruent WCTU values (Hiatt, Sine, Tolbert, 2009). In another example, Dowell, Swaminathan, and Wade (2002) studied the how opponents of high density television advocates engaged in collective framing processes to influence the adoption of HDTV in the United States. By framing HDTV as something that would benefit the Japanese electronics market but hurt the U.S. market (thereby framing HDTV as bad), broadcaster opponents succeeded in keeping HDTV from becoming a 
standard transmission adopted by broadcasters. In sum, as competing actors diffuse incongruent information and frame certain technologies or opportunities as inappropriate, they may have a negative impact on an entrepreneur's decision to adopt a particular technology and on the ability of the focal institutional actor to promote such technologies.

Blending refers to when certain components of promoted values and information are mixed with existing values and cognitions, thereby creating new institutional influences that affect individuals and organizations in unintended ways. Similar to how the amalgamation of red and green light produces yellow, instead of simply dampening the institutional actor's influence to change normative and cognitive understandings, the interaction of promoted beliefs and understandings with competing prescriptions and scripts produces a colorful mix of values and information in which certain components of each influence individuals and organizations in directions not promoted or envisioned by institutional actors.

Competing institutional actors may moderate the effectiveness of focal institutional actors depending on the degree to which their values and information complement the normative prescriptions and cognitions promoted by focal institutional actors. The closer the match, the more the norms and understandings of competing actors may magnify the influence of focal institutional actors. The more incongruent the match, the greater the logics of competing actors will likely dampen or blend promoted prescriptions and understandings. In the following section, I will describe how each kind of moderating effect may occur by examining the competition among agriculture trade associations and environmental movement organizations.

Dampening. If competing institutional actors have more resources and ability to promote their logics than the focal institutional actor, a dampening effect is likely to occur in which the incongruent logics of competing actors overpower those of the 
focal actor, thereby causing individuals and organizations in the local environment to resist conforming to and adopting the values and scripts promoted by the focal institutional actors. In the case of the biodiesel sector, environmental movement lobby organizations opposed biodiesel production technologies that required extensive agricultural practices. Termed "fuel farming," these groups issued numerous media statements, policies, as well as letters to law makers and their members on the potential negative environmental effects of producing biofuels from plant and animal products. Some of these impacts included groundwater and river pollution, the depletion of biodiversity and nutrients from soils, rising food prices, and an increase in the use of forests, wetland and rangeland for agriculture. Illustrating this trepidation towards biofuel production, the largest and most powerful environmental group in the United States, the Sierra Club, stated:

Harvesting forests for fuel has a long history, but raising plants specifically for energy production is a departure from the historical use of plant fiber to produce food and goods. The Sierra Club opposes farming practices which supplant wilderness or other natural land, reduce genetic diversity, require greater energy and material input per unit production, increase use of manufactured fertilizers and biocides on existing agricultural lands, or which displace indigenous people or accelerate the conversion of family farms to corporate agribusiness acreage (Sierra Club, 2000).

Similarly, Friends of the Earth, an international environmental organization with a large presence in the U.S. stated that "the current rush to develop agrofuels (or biofuels) on a large scale is ill-conceived and will contribute to an already unsustainable trade whilst not solving the problems of climate change or energy security" (Friends of the Earth, 2008: 1). 
Other groups such as Greenpeace urged the public to boycott biodiesel produced from companies that promoted unsustainable agricultural practices (Pachter, 2007) and disseminated empirical evidence that biofuels did more ecological harm than good. For example, members of the Nature Conservancy sponsored research published in the journal Science that demonstrated that carbon dioxide emissions generated from the cutting down of rainforests to grow crops for biodiesel would increase for decades or even centuries more than from using traditional fossil fuel (Fargione, Hill, Tilman, Polasky, and Hawthorne, 2008). As competing actors diffuse negative information and frame biodiesel technologies that utilize intensive agricultural practices as wrong and immoral, not only will they likely have a negative impact on entrepreneurial adoption of existing technologies, but also a dampening effect on the efforts of institutional actors (agriculture trade associations) promoting those technologies as individuals who hold environmentally friendly logics resist conforming to the new values and beliefs. Thus, I argue:

Hypothesis 2a: The greater the number of environmental movement actors opposing intensive agricultural-related biodiesel technologies, the lower the founding rate of biodiesel ventures implementing those particular technologies.

Hypothesis 2b: As the number of environmental movement actors increases, the influence of trade associations promoting intensive agriculture related technologies will decrease.

Blending. If competing institutional actors have a moderate to lower ability in comparison to the focal institutional actor to promote specific values and interests, and are not resourceful enough to overpower the promoted scripts and prescriptions of institutional actors, they may cause a blending effect in which certain aspects of the 
promoted logics of competing actors mix with specific aspects of the promoted logics of the focal institutional actor to influence recipients in directions not foreseen. For instance, the blending of two incongruent values and interests could motivate individuals to still found a firm in a controversial sector but seek or develop a new technology not promoted by trade associations and that is harmonious with the prescriptions and scripts espoused by opposition actors.

In the case of the biodiesel sector, many entrepreneurs were influenced by trade associations as well as by the ecological values and beliefs promoted by environmental movement organizations. The blending of the two kinds of prescriptions and cognitions may have produced entrepreneurs both desirous to found a biodiesel venture and motivated to seek or develop substitute technologies that were environmentally friendly. For example, Todd Stephens, a co-founder of Tulsa Biofuels reported that the influence of biodiesel promotion by trade associations and the environmental movement's position on fuel farming affected their decision to found a biodiesel plant and develop feedstock technologies that would be profitable yet ecologically sustainable. He said:

I've been involved in the environmental movement for about a decade, pretty hardcore; I sit on boards and that sort of thing and I'm really into sustainability. You can make biodiesel out of any oil or fat and it can be made out of virgin soybean oil, which is what they do so much of, which is something I'm actually against because it's not sustainable. You're taking away from the food supply. [But] algae are a great. [They're] looking to be a great alternative because they can clean up municipal waste water and they grow very, very quickly. You squeeze that sucker, and you get oil and a nutrient-rich meal which can be turned into biogas. So, algae are definitely the future for feedstock. In the meantime though, we use waste cooking oil, which has lived 
its life and turn that into an alternative fuel, and we feel that's the most sustainable way to do it right now (Stephens, 2008).

In sum, I argue that if an incongruity exists between the information and normative prescriptions of the opposition actors those promulgated by the focal institutional actor and if the competing actor's influence is not as strong as that of the focal institutional actor, there is a greater probability that a blending effect will take place. The result of which will foster unintended foundings of new ventures implementing technologies not promoted by focal trade associations.

Hypothesis 3: As the number of environmental movement actors opposing intensive agricultural technologies increases, trade associations promoting technologies related to agricultural-intensive practices will have an unintended positive influence on the founding of new ventures developing nonpromoted non-intensive agricultural related technologies.

Magnification. On the other hand, if the values and interests of the focal actor align with those of competing institutional actors, the influence of the focal institutional actor may be increased, thereby leading to greater entrepreneurial adoption of that promoted technology. In the case of the biodiesel industry, while environmental movement groups generally attacked the biodiesel sector, not all of the promoted technologies were at the center of the attack. A small handful of promoted biodiesel technologies did not require intensive agricultural practices to produce their raw materials. The environmental benefits for these types of technologies should be more salient and desirable in areas where greater numbers of competing institutional actors promote awareness of the damaging effects of agriculture-intensive biodiesel technologies. The increase in value of technologies related to non-intensive agriculture practices may amplify the effect of the focal actor's promoted normative prescriptions 
and cognitive understandings. Thus, I posit that as values and understandings align between focal and competing institutional actors, the effectiveness of the focal institutional actor changing the institutional environment will increase as individuals become more willing to adopt those practices.

Hypothesis 4a: As the number of environmental movement actors opposing agricultural-intensive biodiesel technologies increases, the founding of new ventures implementing non-intensive agriculture related technologies will increase.

Hypothesis 4b: As the number of environmental movement actors increases, the influence of trade associations promoting non-intensive agriculture related technologies will increase.

\section{Moderating Effects of Network Relations: De Novo vs. De Alio Entrepreneurs}

Entrepreneurial decision-making and susceptibility to the advocacy efforts described above may also be affected by network relations of the entrepreneur. Individuals who found new ventures in a particular sector likely come from a variety of structural-relational contexts, which can affect they way they react to newly promoted prescriptions and understandings. A few empirical studies have documented how network relations can affect the way organizations perceive logics and practices. For example, Rao, Davis and Ward (2000) argued that ties to organizations shaped how firms within the NASDAQ responded to requests from NYSE actors to leave the NASDAQ and join the NYSE. Publicly-traded companies with more ties to companies within the NASDAQ were less likely to be influenced by NYSE pressure to leave and more likely to stay in the NASDAQ because the ties created a greater sense of identity and value among peer firms within the NASDAQ. In another example, Davis and Greve (1997) studied how board interlocks and local organizational ties affected the 
way organizations perceived newly promoted business practices: poison pills and golden parachutes. They concluded that ties and interlocks to organizations that had adopted such practices shaped their view of legitimacy of those practices, thereby leading to greater adoption. Thus, relational structures may have a significant influence on companies' judgments and values of what is important and what is not. Similarly, it is likely that entrepreneurs with ties to firms or individuals immersed in distinct institutional contexts may respond differently to institutional actors promoting technological prescriptions and beliefs as their ties may affect how they view certain aspects of the institutional environment.

Two types of entrepreneurs that may be distinctly embedded and respond differently to prescription and information diffused by institutional actors are de novo and de alio entrants. De novo entrepreneurs start ventures without direct linkages to or sponsorship from other organizations, while de alio entrepreneurs are sponsored by companies in that area (Carroll and Hannan, 2000). To offer an example, in the case of the biodiesel industry, Tulsa Biofuels, co-founded by three individuals not connected to or sponsored by another organization, would be a de novo entrant while the founding of Paseo Cargill Energy LLC, started with resources and sponsorship from Cargill—a soybean crushing giant—would be a de alio entrant.

Previous research on de novo and de alio entrepreneurs has found that de novo entrepreneurs tend to be more focused on the cultural and economic environment of the new sector because they are not connected to or retain activities from other industries (McKendrick, Jaffee, Carroll, \& Khessina, 2003). Because de novo entrepreneurs tend to have fewer available resources at startup than de alio entrants, they may have a greater motivation to become isomorphic with the environment and espouse the local prescriptions and cognitions in an effort to garner greater local legitimacy. 
On the other hand, because de alio entrepreneurs often found organizations with greater available resources than de novo entrants, they may not be as motivated to engage in actions that will generate local legitimacy. Additionally, de alio entrepreneurs draw upon resources and technological expertise from origin companies, creating a resource dependence in which they often need to report to and justify their actions to interested sponsors and critics from other external environments (Carroll, Bigelow, Seidel, \& Tsai, 1996). Thus, slack resources and pressures to report and appear legitimate to external organizations may cause de alio entrepreneurs to be more concerned about conforming to the external cultural beliefs and values of the external organizations to which they have ties than those of the focal environment. This could negatively moderate the influence that focal and competing institutional actors have on their technological choices.

Interviews with de alio entrants in the biodiesel sector provide support for this argument. For example, an entrepreneur from a de alio biodiesel venture noted that while they were located in Illinois, a state with a powerful trade association, they did not feel pressure to heed the association's prescriptions or information to adopt soybean production technologies. Instead, their technological choices were largely based on the economic and social demands of the chemical sector where their parent company was located. He noted:

We're an oddball in that we're also a large specialty chemical company. When biodiesel came around, all we had to do was roll over our existing assets. But biodiesel isn't our primary business, and we don't necessarily bring in and convert soybean oil. We use other oils to make detergent-type products and biodiesel esters. We don't have to make biodiesel, but we're committed to it and we're in it for the long haul. 
I posit that because de novo entrepreneurs have a greater need for legitimacy in the focal environment, they will be more susceptible to the influence of strong institutional actors in their geographic area. In contrast, because de alio entrants are likely to respond to the cultural and cognitive understandings of other environmental contexts due to their ties to external organizations, they will be less likely to adopt the values and beliefs of focal and competing institutional actors than their de novo counterparts, thereby dampening the influence of institutional actors.

Hypothesis 5a: Greater numbers of trade association members promoting biodiesel technologies will have a greater positive effect on the adoption of that technology among de novo than de alio entrants.

Hypothesis 5b: Greater numbers of environmental movement actors opposing intensive-agriculture technologies will have a greater negative effect on the adoption of agricultural-intensive technologies and a greater positive effect on adoption of non-intensive agriculture biodiesel technologies among de novo than de alio entrants.

\section{Methods}

In this study, I focus on the moderating effects of competing institutional actors and network relations on a focal institutional actor's ability to influence entrepreneurial decision-making. Empirically, I analyze how the norms and beliefs of the local institutional environment (as measured by the presence of opposition actors) and network relations can moderate the influence of agriculture trade associations on biodiesel foundings and technological choice. The window of observation is 1990 to 2008. I use 1990 as the base year because that is the year that agriculture trade associations began sponsoring biodiesel university research and promoting such 
technologies and I end data collection on December 31, 2008. A total of 267 biodiesel production plants were founded during this period. Of the 267 foundings, 223 were de novo and 44 were de alio entrants.

Dependent Variables. The dependent variables for this study are technologyspecific biodiesel founding events in a given state-year. I focus on the five most prominent biodiesel transesterification technologies related to soybean, canola, cottonseed, animal fats, and waste vegetable oil. Data on biodiesel producers come from quarterly reports generated by the National Biodiesel Board as well as archival reports from individual producers. From this information I am able to measure when each biodiesel plant began and ceased operation, the total number of biodiesel plants operating in a state, whether they are de alio or de novo, their contact information, their total production capacity, and the feedstock technology they used over time. I coded biodiesel ventures as de alio if media reports on their foundings (such as articles published in Biodiesel Magazine) mentioned their origin company.

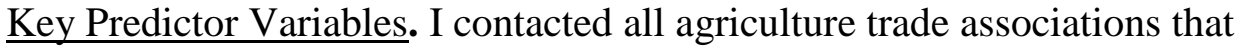
represent producers of organic oils in the United States to find out whether they had promoted biodiesel. Six trade associations reported to have actively promoted biodiesel production technologies, namely, the American Soybean Association, National Renderers Association, United States Canola Association, National Corn Growers Association, National Sunflower Association, and the National Cottonseed Producers Association. Because many of these organizations are federative in nature, the state chapters are free to decide when and what they will promote. I contacted every state and national organization and obtained information on their membership, the dates of when the state chapters and national organizations began promoting biodiesel as well as information on the promotion tactics they used. Because information on promotion tactics was limited, I left them out of the analysis. The first 
trade association to sponsor university research and promote biodiesel technologies was the Missouri chapter of the American Soybean Association in 1990.

I measured the strength of individual trade associations by using the total number of active members of each trade association promoting a specific technology in a given state-year. If a state trade association was not promoting biodiesel, membership size was tallied as 0 . However, once they began promoting biodiesel, I used their actual size in membership to measure their influence. Because I am also concerned with the moderating effect of competing institutional actors, I control for environmental members that are skeptical and antagonistic of certain biodiesel production technologies. I included a variable of state-level membership data from the Sierra Club, which, over my time period, was the largest grass-roots environmental organization and one of the most vocal against unsustainable biofuels in the United States. $^{3}$

Control Variables. I controlled for the general state economic activity by including gross state product per capita and state population. Information on state population comes from the U.S. Census Bureau, while gross state product is obtained from the U.S. Department of Commerce. Because local access to biodiesel raw materials can affect the decision of entrepreneurs to found a biodiesel plant (Baker and Nelson, 2005; Sine and Lee, 2009), I controlled for the total amount of locally available raw materials and their price by calculating the total pounds of animal fats, plant oils and waste vegetable oil (yellow grease) produced by state. I calculated the

\footnotetext{
${ }^{3}$ I also created a variable that measured the number of non-governmental environmental organizations in a state by year and found similar yet weak results. The data come from the Conservation Directory, a yearly publication that reports all governmental and nonprofit environmental organizations in operation by state. However, this data is limited in that it does not report the organizations' membership. Thus, we cannot accurately estimate size. Because of this, I used membership of the Sierra Club by state to measure the influence of environmental movement lobbying groups on entrepreneurs.
} 
pounds of rendered animal fats by taking the pounds of pigs, cattle, and poultry slaughtered by state and computing the average percent of rendered fat per animal as determined by the National Renderers Association (Meeker, 2006). I calculated the amount of plant oils by summing the total bushels of sunflower, safflower, canola, rapeseed, soybean, corn, peanuts, cottonseed, and flaxseed harvested in a state and computing the average pounds of oil derived from each type of seed as determined by the United States Department of Agriculture’s (USDA) National Agricultural Statistical Service. The data reveal the annual amount of crops harvested and animals slaughtered and the commodity prices for each type of oil and fat by year. As a measure of the pounds of waste vegetable oil produced by state, I counted the total number of food establishments per state and multiplied this by 372 pounds per month, the average amount of waste vegetable oil discarded by a restaurant (Vernet, 2005). The number of food service establishments comes from the U.S. Census Bureau's Economic Census. I then created a proportion variable by dividing the amount of technology-corresponding raw material fats by the total amount of fats and oils (in pounds) of biodiesel raw material sources in a given state-year.

Prior research has found that organizational density can affect the amount of available resources and thereby influence new-venture foundings and the propensity to innovate (Hannan and Freeman, 1977; Katila and Shane, 2005). As such, I controlled for competition by summing the number of operating biodiesel plants using a specific technology in each state by year. Given that profitability can affect the decision of entrepreneurs to adopt a particular technological process, I controlled for profitability in the models of founding, technological innovation and diversity by taking the average price of retail diesel sold in a state and subtracting it from the sum of the average cost of labor, capital, and chemical transesterification costs, and the annual average price of biodiesel raw materials per gallon using a weighted index score of 
feedstock spot prices recorded by the USDA's National Agricultural Statistical Service. I calculated the labor and chemical costs by adding 81 cents to a gallon biodiesel (the industry average for labor and capital costs) with the price of methanol needed to make a gallon of biodiesel. I obtained data on state average retail diesel prices from U.S. Department of Energy. I then created a technology-specific profitability variable by subtracting the price of retail diesel fuel from the total labor, chemical costs and the average price of the corresponding raw material (Van Gerpen, Pruszko, Clements, Shanks, and Knothe, 2006). Included in the profitability variable was the 2005 federal subsidy of biodiesel. The subsidy provided a tax credit of $\$ 1.00$ per gallon for technologies that transformed oilseed crops into biodiesel and \$.50 per gallon for technologies that transformed other kinds of feedstocks such as animal fats and yellow grease into biodiesel.

Finally, I supplemented archival data with thirty-two interviews with biodiesel founders and twenty-six interviews with state and national agriculture trade associations and Sierra Club organization members across the nation. The interviews represented every technology developed and implemented during this time period. The

interview data grounded my choice of measures and strengthened my understanding of hypothesized structural relationships.

\section{Analysis}

Biodiesel entrants must choose from among a host of potential biodiesel production processes. In order to accurately measure the influence of a particular institutional actor in a given state-year on the founding of a biodiesel venture using a specific technological process, I used a competing risks regression. A competing risk is defined as an "event whose occurrence either precludes the occurrence of another event under investigation or fundamentally alters the probability of occurrence of this other event” (Gooley, Leisenring, Crowley, and Storer,1999: 695). Much of the 
previous work on competing risks has relied upon Kaplan-Meier estimates (1-KM) from conventional event-history analyses to measure the prevalence of an event of interest. However, using a Kaplan-Meier distribution function to produce a cumulative incident function creates a biased estimate of the event of interest because competing events are treated as if they were censored. One has to assume that the event of interest, or type 1 event, occurs where type 2 or type 3 events do not (Gooley, Leisenring, Crowley, and Storer, 1999).

Unlike conventional hazard analyses, the competing risks regression uses the cumulative incidence function (CIF) which considers not only the subhazard for the event of interest type $1, h_{1}(t)$, but also the subhazards of concurrent competing events, $h_{2}(t), h_{3}(t)$, and $h_{i}(t)$. Thus, a competing-risks regression treats the CIF as a function of all hazards [e.g. $\left.h_{1}(t), h_{2}(t), h_{3}(t), h_{i}(t)\right]$ whereas conventional measures of prevalence (1-KM) treat the CIF as a function solely of $h_{1}(t)$. The competing risks regression is based on the model by Fine and Gray (1999) and is similar to the Cox semi-parametric model. The general form is given as:

$$
\mathrm{h}_{1}(\mathrm{t})=\mathrm{h}_{1,0}(\mathrm{t}) \exp (\beta \mathrm{x})
$$

where $h_{1}(t)$ is the subhazard function of interest, $x$ is a vector of covariates, $\beta$ is a vector of subhazard ratios, and $\mathrm{h}_{1,0}(\mathrm{t})$ is the baseline subhazard rate for covariates set to zero. Because competing risks regressions take into account the probability of other competing technological choices, it is a highly robust analysis to measure the impact of a variety of institutional actors as well as the moderating effects of the local cultural milieu and relational structures on entrepreneurial choice. Finally, some of my variables were highly correlated (such as trade association membership and the interaction of trade association and the institutional environment) which can inflate standard errors and makes regression coefficients unstable. To deal with the multicollinearity, I used a Gram-Schmidt procedure which partials out the common 
variance between these highly correlated variables and creates transformed variables that are uncorrelated with each other (Cohen and Cohen, 1983; Saville and Wood, 1991).

\section{Results}

The first biodiesel founding occurred in 1993 in Missouri, with one or two more a year in a few other states. Foundings began to increase beginning in 2002 and by 2007, the states averaged 1.70 foundings per year with Texas leading the way with 8.5 foundings per year. Descriptive statistics and bivariate correlations for analyses in table 1 . The results of competing risks regressions predicting founding events with particular agriculture-intensive related technologies among all entrants are found in table 2 while the competing risks regressions predicting founding events with specific non-intensive agriculture related technologies are reported in table 3. Competing risks regressions of de novo entrants adopting agriculture-intensive and non- intensive agriculture related technologies are reported in tables 4 and 5 respectively, and results of de alio entrants adopting agriculture-intensive and non-intensive agriculture related technologies are reported in tables 6 and 7 respectively. 
Table 1

Descriptive Statistics and Bivariate Correlations

\begin{tabular}{rlcc}
\hline & \multicolumn{1}{c}{ Variable } & Mean & Std. Dev. \\
\hline $\mathbf{1}$ & State population & 5448646 & 6068711 \\
$\mathbf{2}$ & Gross state product per capita & 0.033 & 0.014 \\
$\mathbf{3}$ & Soybean technology density & 0.086 & 0.375 \\
$\mathbf{4}$ & Soybean technology profitability & -22.058 & 51.478 \\
$\mathbf{5}$ & Soybean technology raw materials & 0.232 & 0.249 \\
$\mathbf{6}$ & Cottonseed technology density & 0.005 & 0.085 \\
$\mathbf{7}$ & Cottonseed technology profitability & -59.469 & 54.114 \\
$\mathbf{8}$ & Cottonseed technology raw materials & 0.048 & 0.109 \\
$\mathbf{9}$ & Tallow technology density & 0.020 & 0.153 \\
$\mathbf{1 0}$ & Tallow technology profitability & 17.045 & 51.441 \\
$\mathbf{1 1}$ & Tallow technology raw materials & 0.225 & 0.231 \\
$\mathbf{1 2}$ & Corn technology density & 0.004 & 0.064 \\
$\mathbf{1 3}$ & Corn technology profitability & -145.707 & 69.133 \\
$\mathbf{1 4}$ & Corn technology raw materials & 0.188 & 0.184 \\
$\mathbf{1 5}$ & Canola technology density & 0.011 & 0.115 \\
$\mathbf{1 6}$ & Canola technology profitability & -54.313 & 39.414 \\
$\mathbf{1 7}$ & Canola technology raw materials & 0.010 & 0.035 \\
$\mathbf{1 9}$ & Sunflower technology profitability & -150.691 & 58.500 \\
$\mathbf{2 0}$ & Sunflower technology raw materials & 47719 & 241818 \\
$\mathbf{2 1}$ & Yellow grease technology density & 0.035 & 0.238 \\
$\mathbf{2 2}$ & Yellow grease technology profitability & 41.241 & 48.638 \\
$\mathbf{2 3}$ & Yellow grease technology raw materials & 0.233 & 0.317 \\
$\mathbf{2 4}$ & American soybean association & 360 & 849 \\
$\mathbf{2 5}$ & National renderers association & 1.714 & 2.772 \\
& National cottonseed producers & & \\
$\mathbf{2 6}$ & association & 0.279 & 1.362 \\
$\mathbf{2 7}$ & National corn growers association & 671 & 1392 \\
$\mathbf{2 8}$ & United State canola association & 1.585 & 14.332 \\
$\mathbf{2 9}$ & National sunflower association & 0.2693 & 0.7543 \\
$\mathbf{3 0}$ & Sierra Club & 12609 & 25392 \\
& & &
\end{tabular}


Table 1 (Continued)

\begin{tabular}{ccccccccc}
\hline & $\mathbf{1}$ & $\mathbf{2}$ & $\mathbf{3}$ & $\mathbf{4}$ & $\mathbf{5}$ & $\mathbf{6}$ & $\mathbf{7}$ & $\mathbf{8}$ \\
\hline 1 & 1 & & & & & & & \\
2 & -0.001 & 1 & & & & & & \\
3 & 0.176 & 0.049 & 1 & & & & & \\
4 & 0.014 & 0.322 & 0.136 & 1 & & & & \\
5 & 0.008 & -0.169 & 0.051 & -0.090 & 1 & & & \\
6 & 0.187 & 0.035 & 0.376 & 0.074 & -0.053 & 1 & & \\
7 & -0.010 & 0.169 & 0.007 & 0.726 & -0.084 & 0.043 & 1 & \\
8 & 0.385 & -0.134 & 0.103 & -0.053 & -0.076 & 0.169 & -0.011 & 1 \\
9 & 0.023 & 0.017 & 0.493 & 0.083 & 0.094 & 0.151 & -0.054 & 0.014 \\
10 & 0.017 & 0.315 & 0.186 & 0.912 & -0.074 & 0.086 & 0.584 & -0.055 \\
11 & 0.065 & -0.149 & 0.024 & -0.014 & -0.244 & 0.019 & -0.037 & 0.042 \\
12 & 0.041 & -0.006 & 0.286 & 0.025 & -0.006 & 0.186 & -0.048 & 0.059 \\
13 & 0.017 & 0.357 & 0.072 & 0.750 & -0.075 & 0.052 & 0.719 & -0.033 \\
14 & -0.057 & -0.115 & 0.081 & 0.014 & 0.267 & -0.007 & -0.001 & -0.275 \\
15 & 0.013 & 0.008 & 0.264 & 0.071 & -0.046 & 0.099 & -0.046 & -0.008 \\
16 & -0.014 & 0.197 & -0.023 & 0.839 & -0.122 & 0.034 & 0.844 & -0.033 \\
17 & -0.173 & -0.107 & -0.047 & -0.005 & -0.116 & -0.018 & 0.004 & -0.069 \\
18 & -0.012 & 0.104 & 0.033 & 0.448 & -0.105 & 0.009 & 0.622 & -0.021 \\
19 & -0.113 & -0.060 & 0.025 & -0.017 & 0.062 & 0.007 & -0.022 & -0.076 \\
20 & 0.286 & 0.065 & 0.498 & 0.130 & -0.088 & 0.298 & 0.041 & 0.160 \\
21 & 0.017 & 0.334 & 0.199 & 0.920 & -0.082 & 0.086 & 0.551 & -0.062 \\
22 & -0.121 & 0.410 & -0.116 & 0.118 & -0.574 & -0.032 & 0.109 & -0.171 \\
23 & 0.015 & -0.028 & 0.083 & -0.002 & 0.592 & -0.021 & -0.023 & -0.164 \\
24 & 0.518 & 0.102 & 0.418 & 0.222 & 0.195 & 0.364 & 0.040 & 0.208 \\
25 & 0.238 & 0.054 & 0.606 & 0.186 & 0.078 & 0.524 & 0.037 & 0.137 \\
26 & 0.072 & -0.038 & 0.089 & -0.025 & 0.548 & -0.021 & -0.024 & -0.140 \\
27 & 0.046 & 0.028 & 0.023 & 0.067 & 0.037 & -0.007 & 0.022 & 0.032 \\
28 & 0.171 & 0.124 & 0.358 & 0.270 & 0.024 & 0.301 & 0.130 & 0.087 \\
29 & 0.833 & 0.065 & 0.124 & 0.060 & -0.133 & 0.028 & 0.036 & 0.344
\end{tabular}


Table 1 (Continued)

\begin{tabular}{|c|c|c|c|c|c|c|c|c|}
\hline & 9 & 10 & 11 & 12 & 13 & 14 & 15 & 16 \\
\hline 9 & 1 & & & & & & & \\
\hline 10 & 0.140 & 1 & & & & & & \\
\hline 11 & 0.016 & -0.061 & 1 & & & & & \\
\hline 12 & 0.202 & 0.054 & 0.017 & 1 & & & & \\
\hline 13 & -0.009 & 0.594 & 0.019 & -0.022 & 1 & & & \\
\hline 14 & 0.016 & 0.039 & -0.287 & 0.029 & -0.012 & 1 & & \\
\hline 15 & 0.221 & 0.123 & 0.089 & 0.273 & -0.011 & 0.001 & 1 & \\
\hline 16 & -0.060 & 0.712 & -0.008 & -0.056 & 0.716 & -0.019 & -0.042 & 1 \\
\hline 17 & -0.036 & -0.012 & -0.148 & -0.002 & 0.010 & -0.081 & -0.003 & 0.019 \\
\hline 18 & -0.042 & 0.245 & 0.031 & -0.018 & 0.596 & -0.002 & -0.029 & 0.566 \\
\hline 19 & -0.012 & -0.014 & -0.132 & -0.009 & -0.027 & -0.031 & -0.006 & -0.014 \\
\hline 20 & 0.350 & 0.176 & 0.047 & 0.329 & 0.075 & -0.021 & 0.324 & 0.021 \\
\hline 21 & 0.147 & 0.989 & -0.059 & 0.059 & 0.596 & 0.041 & 0.129 & 0.692 \\
\hline 22 & -0.073 & 0.125 & -0.391 & -0.039 & 0.089 & -0.305 & -0.017 & 0.138 \\
\hline 23 & 0.101 & -0.002 & -0.238 & -0.011 & 0.028 & 0.344 & -0.031 & -0.032 \\
\hline 24 & 0.188 & 0.253 & 0.007 & 0.140 & 0.224 & 0.100 & 0.121 & 0.065 \\
\hline 25 & 0.449 & 0.254 & -0.015 & 0.223 & 0.088 & 0.005 & 0.157 & -0.004 \\
\hline 26 & 0.070 & -0.025 & -0.212 & -0.020 & -0.020 & 0.317 & -0.034 & -0.033 \\
\hline 27 & -0.008 & 0.075 & 0.076 & 0.020 & 0.060 & -0.051 & 0.012 & 0.017 \\
\hline 28 & 0.050 & 0.282 & 0.014 & 0.126 & 0.253 & 0.127 & 0.201 & 0.167 \\
\hline \multirow[t]{2}{*}{29} & -0.013 & 0.063 & 0.066 & -0.004 & 0.055 & -0.085 & 0.010 & 0.042 \\
\hline & 17 & 18 & 19 & 20 & 21 & 22 & 23 & 24 \\
\hline 17 & 1 & & & & & & & \\
\hline 18 & 0.008 & 1 & & & & & & \\
\hline 19 & 0.516 & -0.030 & 1 & & & & & \\
\hline 20 & -0.033 & 0.027 & -0.018 & 1 & & & & \\
\hline 21 & -0.009 & 0.246 & -0.012 & 0.183 & 1 & & & \\
\hline 22 & -0.088 & 0.087 & -0.147 & -0.007 & 0.133 & 1 & & \\
\hline 23 & -0.075 & -0.020 & 0.033 & -0.054 & -0.003 & -0.313 & 1 & \\
\hline 24 & -0.143 & -0.013 & -0.044 & 0.331 & 0.276 & -0.239 & 0.279 & 1 \\
\hline 25 & -0.055 & 0.062 & -0.017 & 0.405 & 0.260 & -0.091 & 0.077 & 0.466 \\
\hline 26 & -0.029 & -0.022 & 0.150 & -0.047 & -0.027 & -0.330 & 0.896 & 0.282 \\
\hline 27 & -0.026 & 0.001 & -0.019 & -0.007 & 0.078 & -0.067 & 0.003 & 0.093 \\
\hline 28 & -0.083 & 0.092 & 0.045 & 0.164 & 0.288 & -0.090 & 0.056 & 0.448 \\
\hline \multirow[t]{7}{*}{29} & -0.089 & 0.020 & -0.068 & 0.320 & 0.065 & 0.024 & -0.032 & 0.423 \\
\hline & & & 25 & 26 & 27 & 28 & & \\
\hline & & & 1 & & & & & \\
\hline & & & 0.064 & 1 & & & & \\
\hline & & & -0.012 & 0.166 & 1 & & & \\
\hline & & & 0.235 & 0.098 & 0.110 & 1 & & \\
\hline & & & 0.148 & 0.030 & 0.016 & 0.106 & & \\
\hline
\end{tabular}




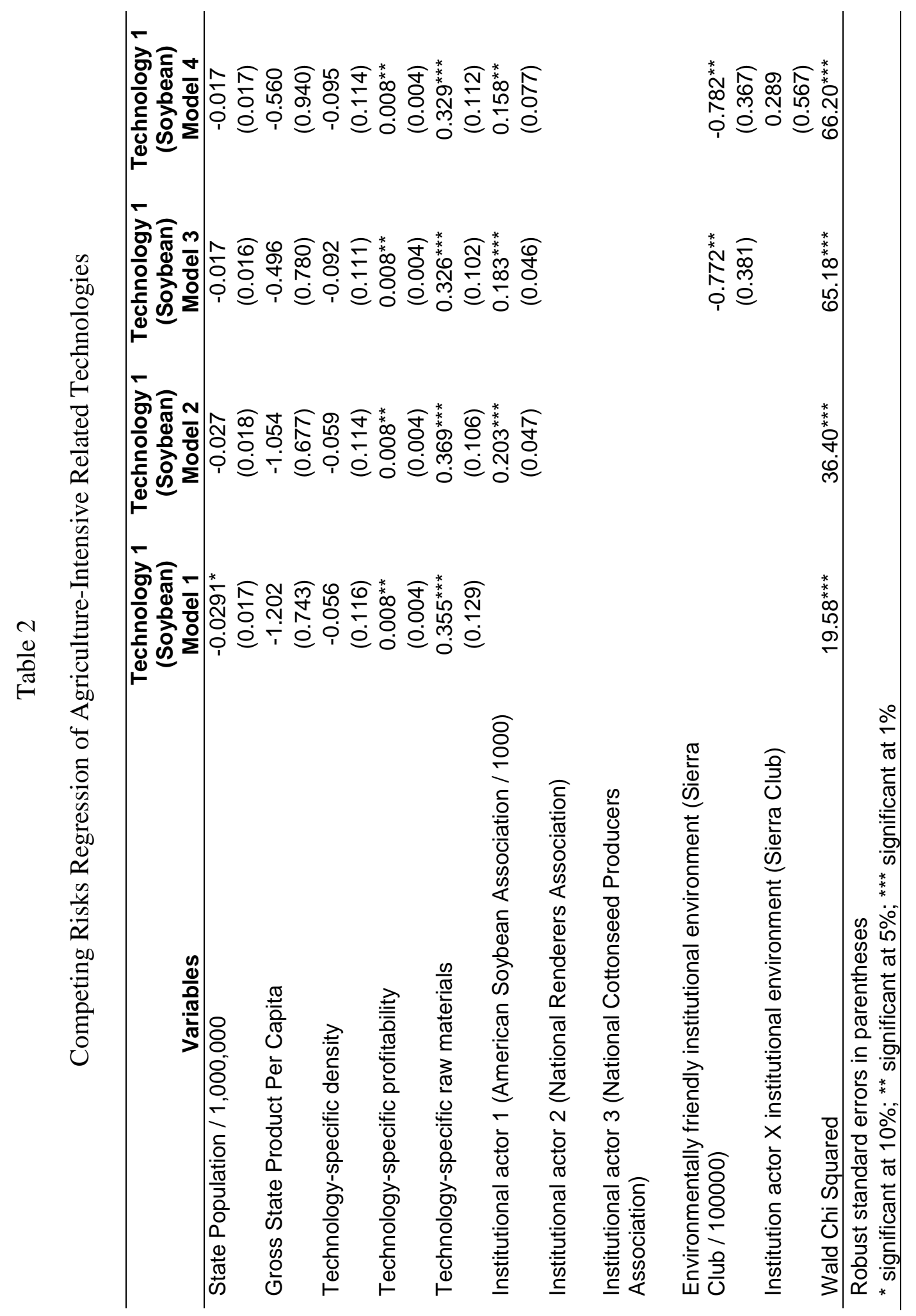




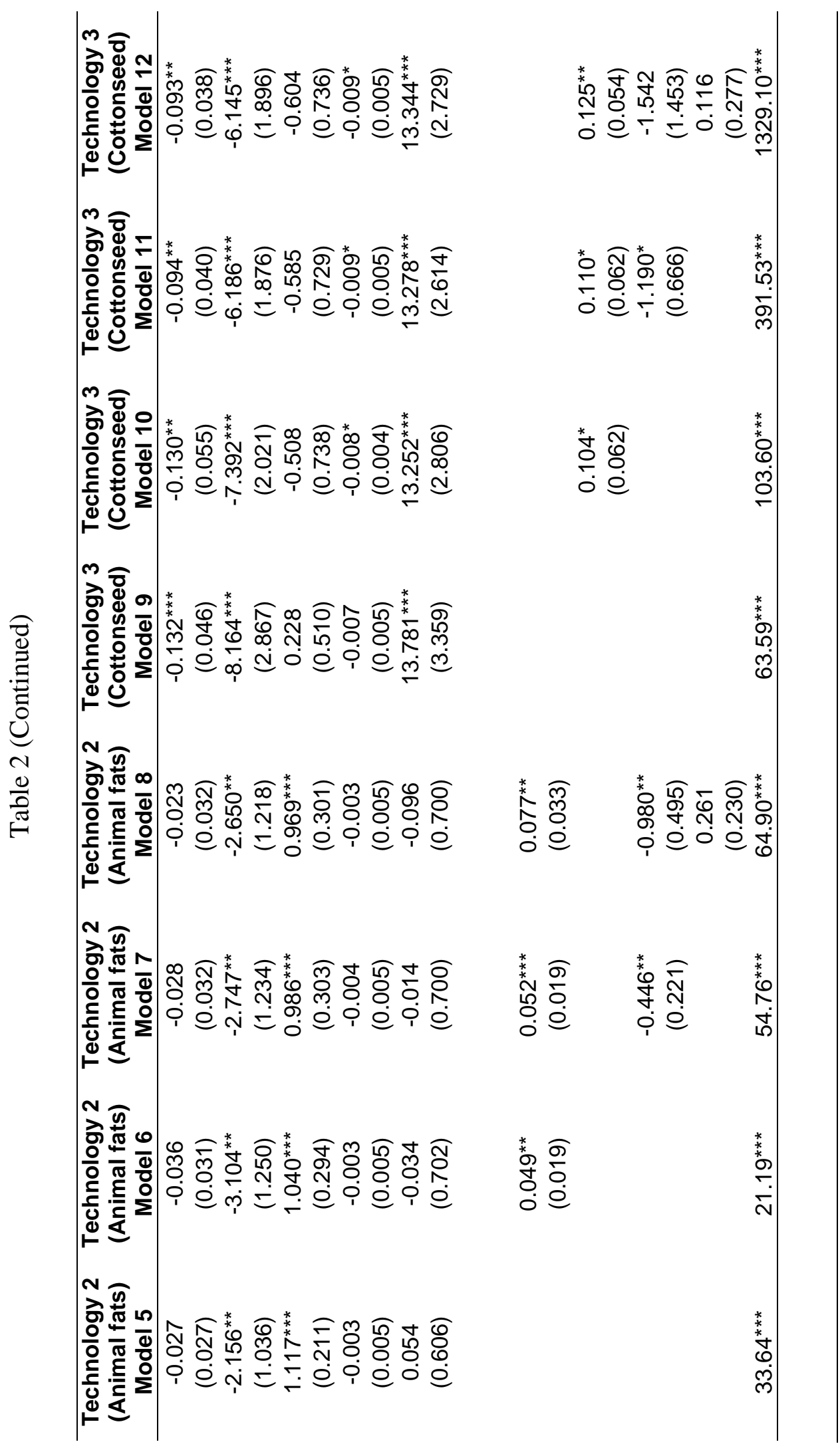




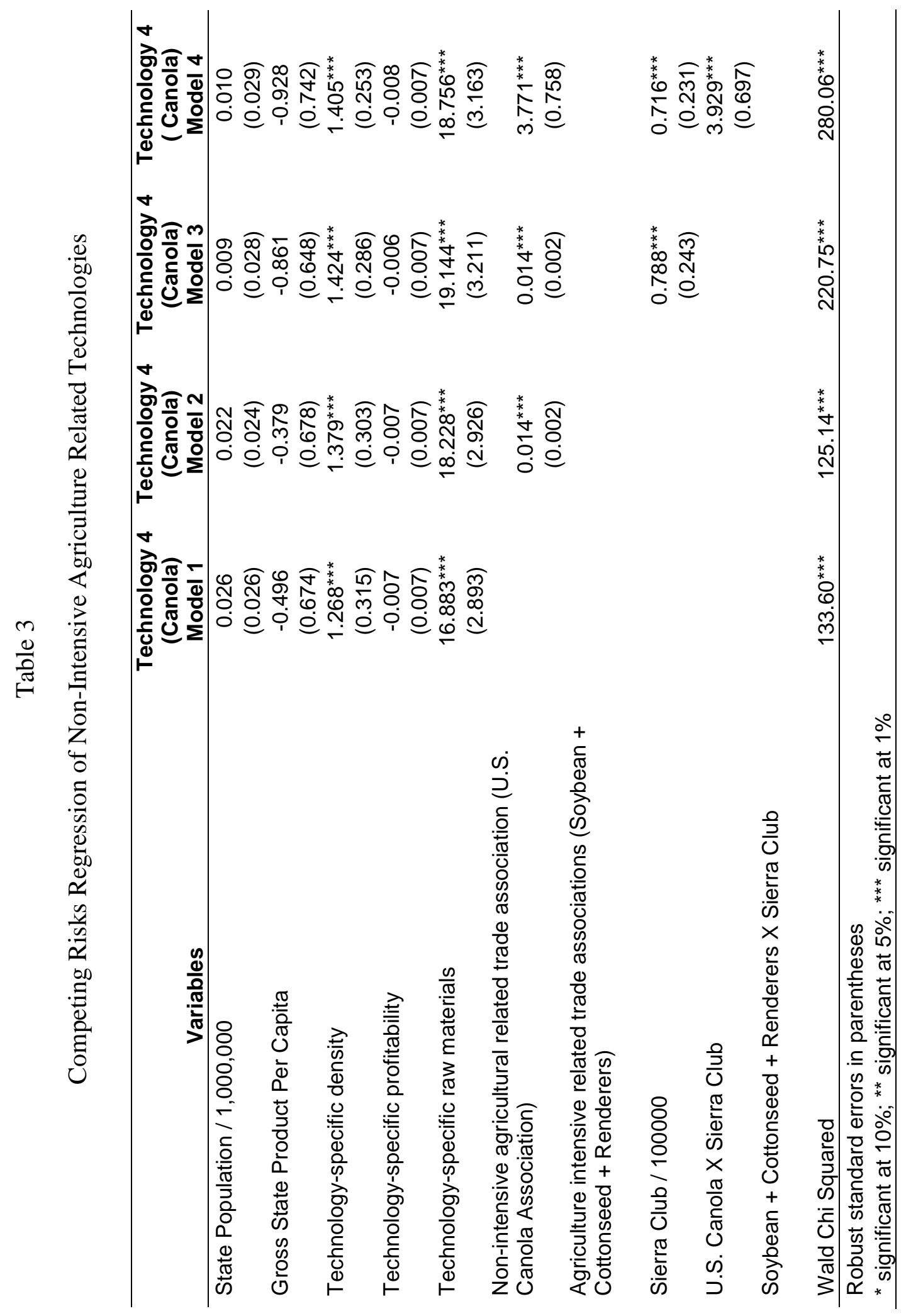




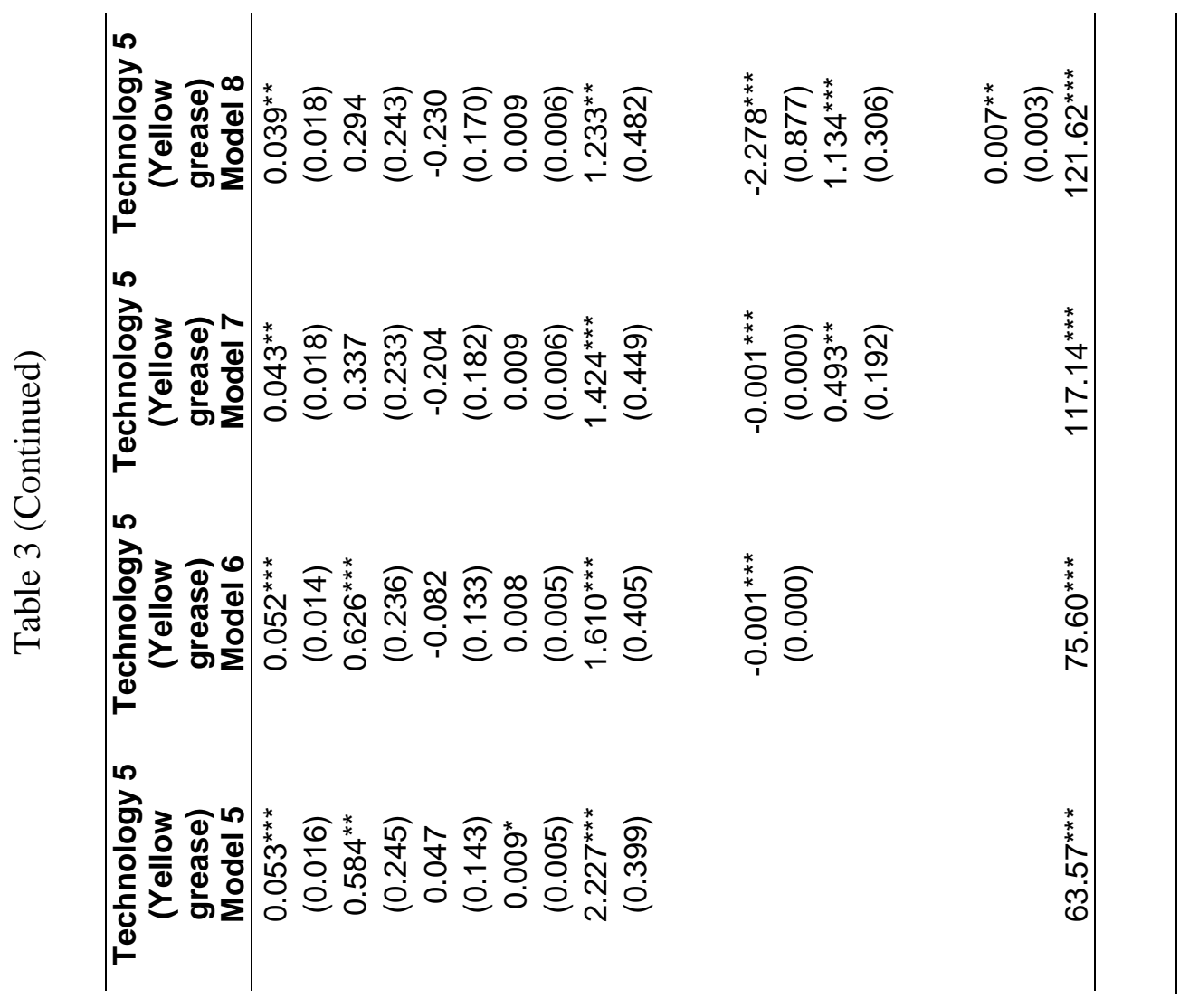




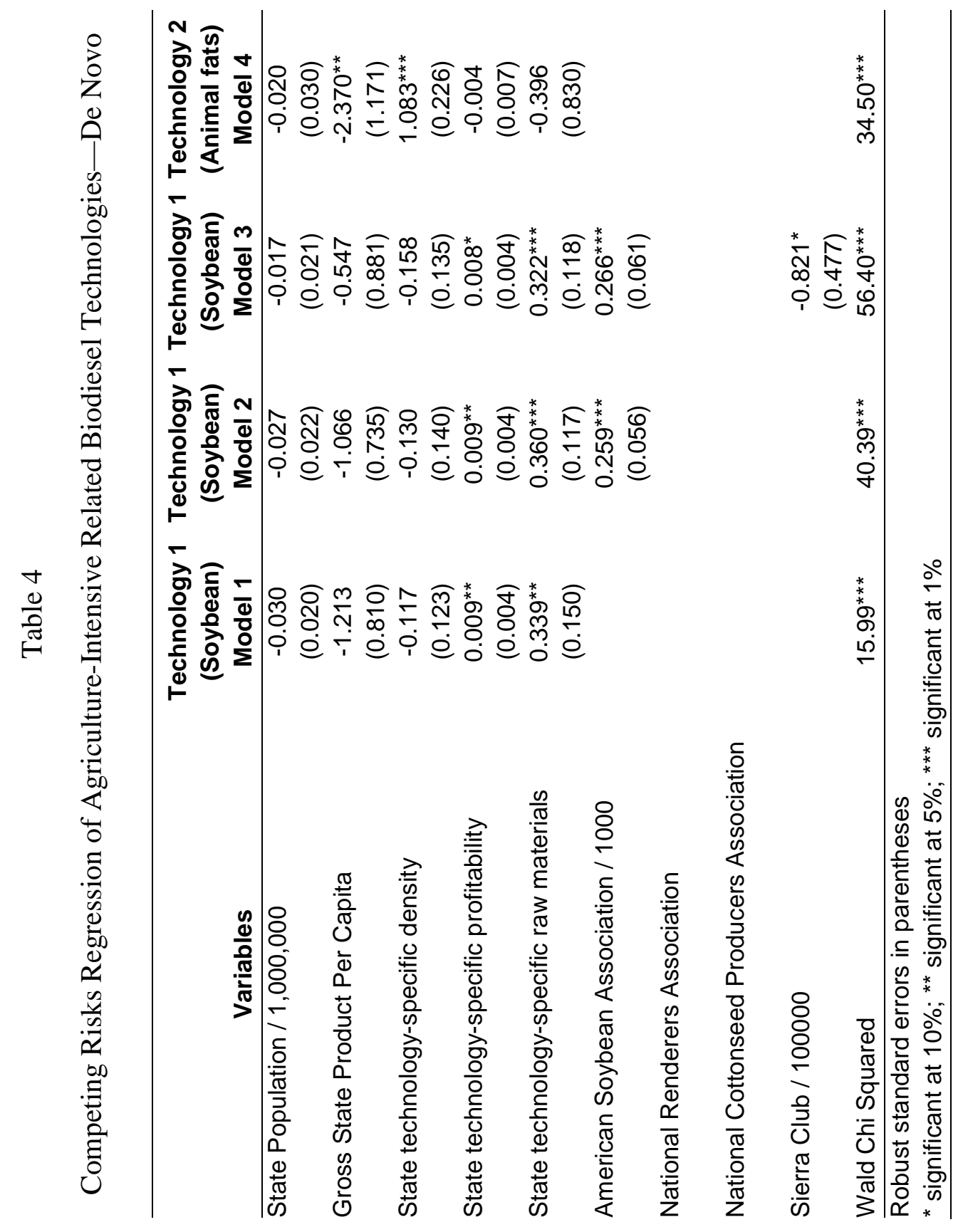




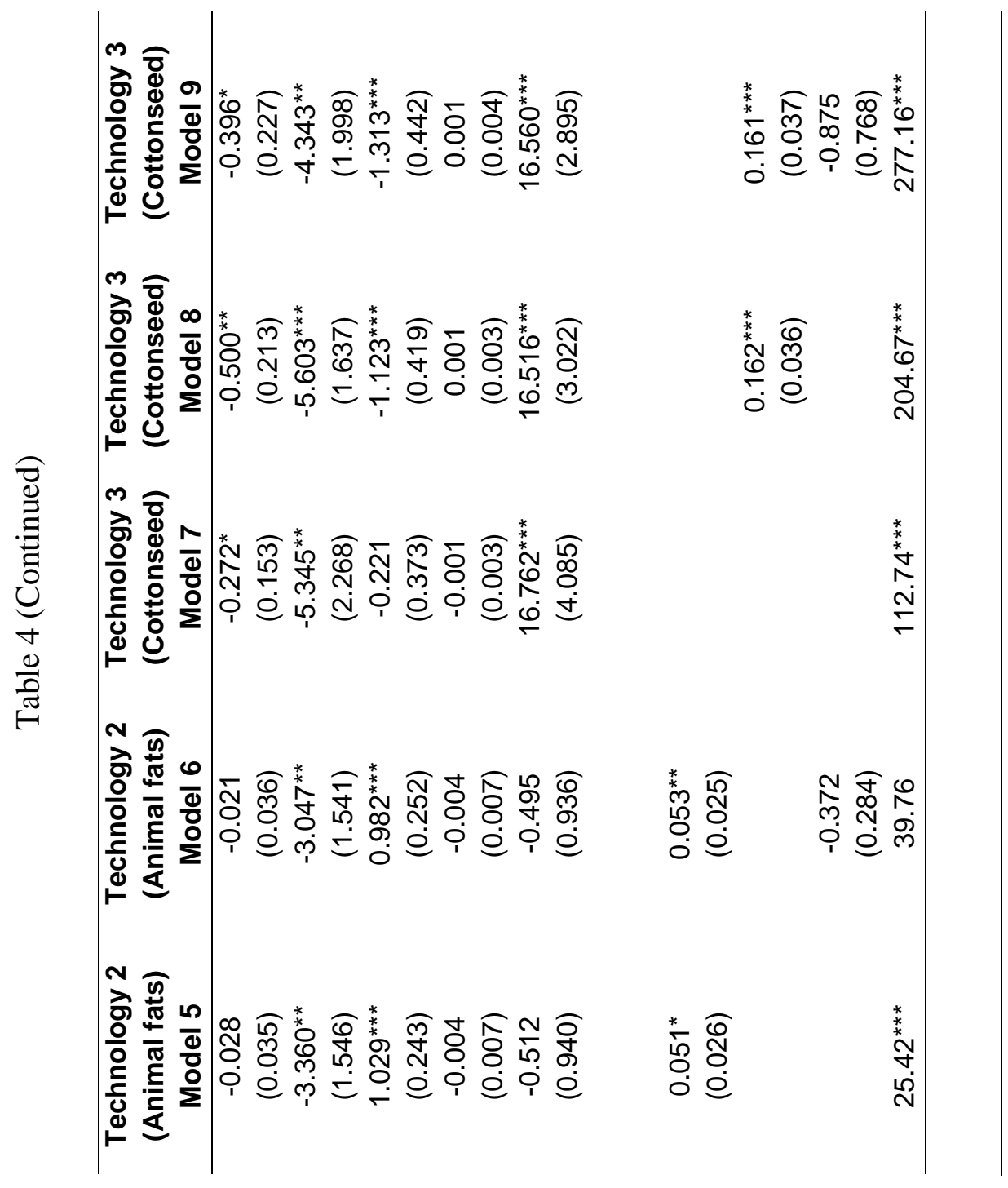




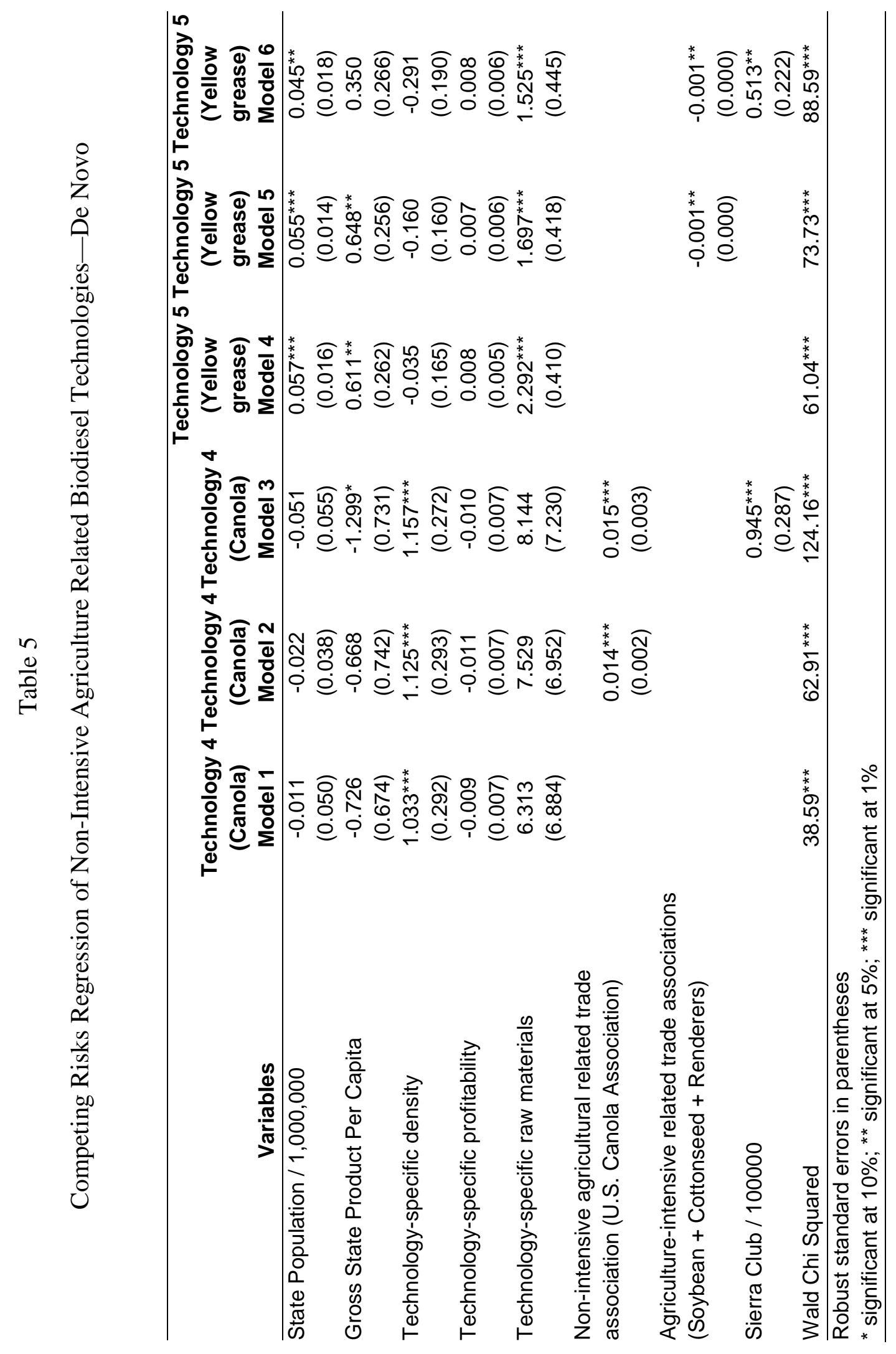




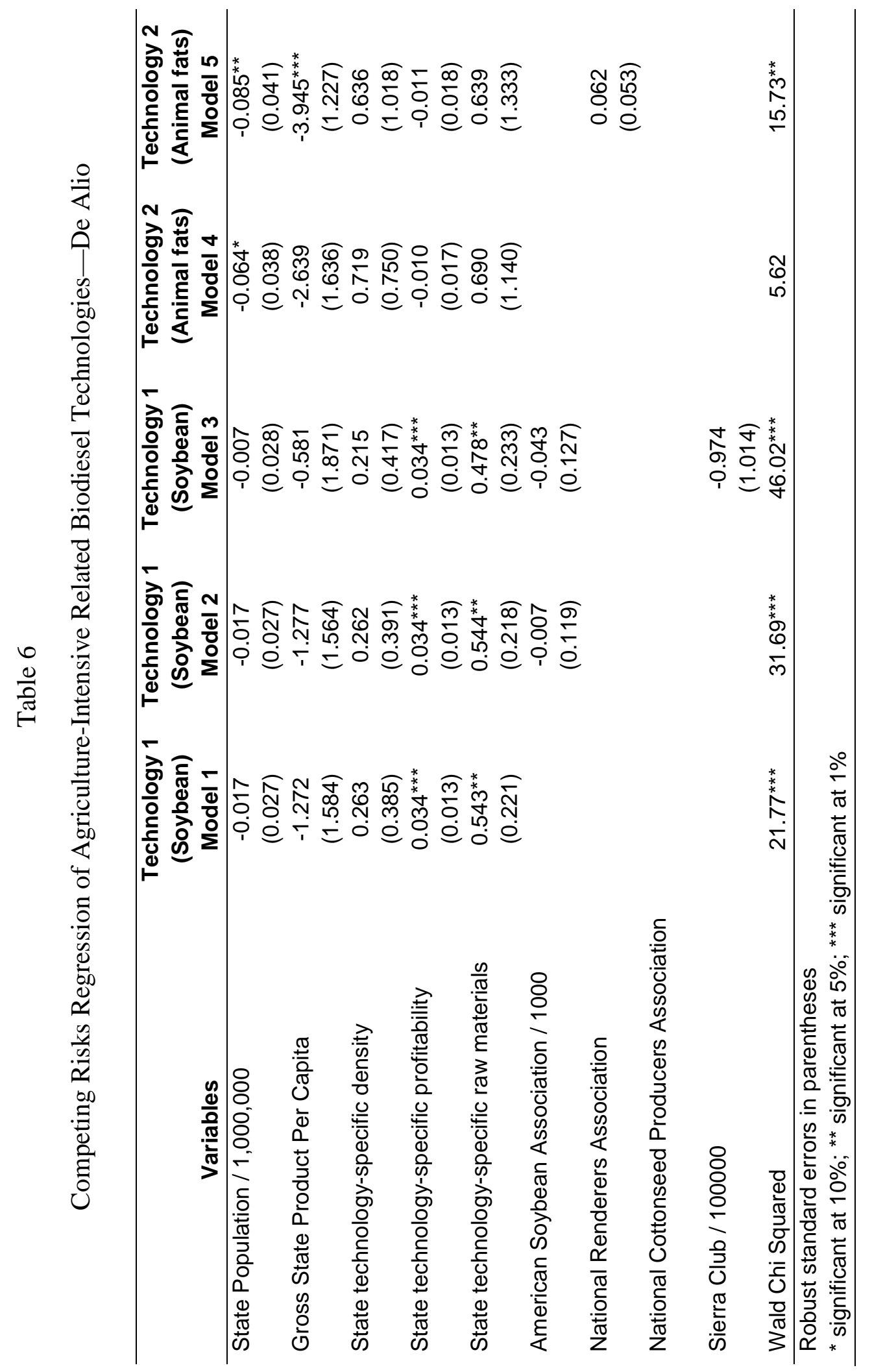



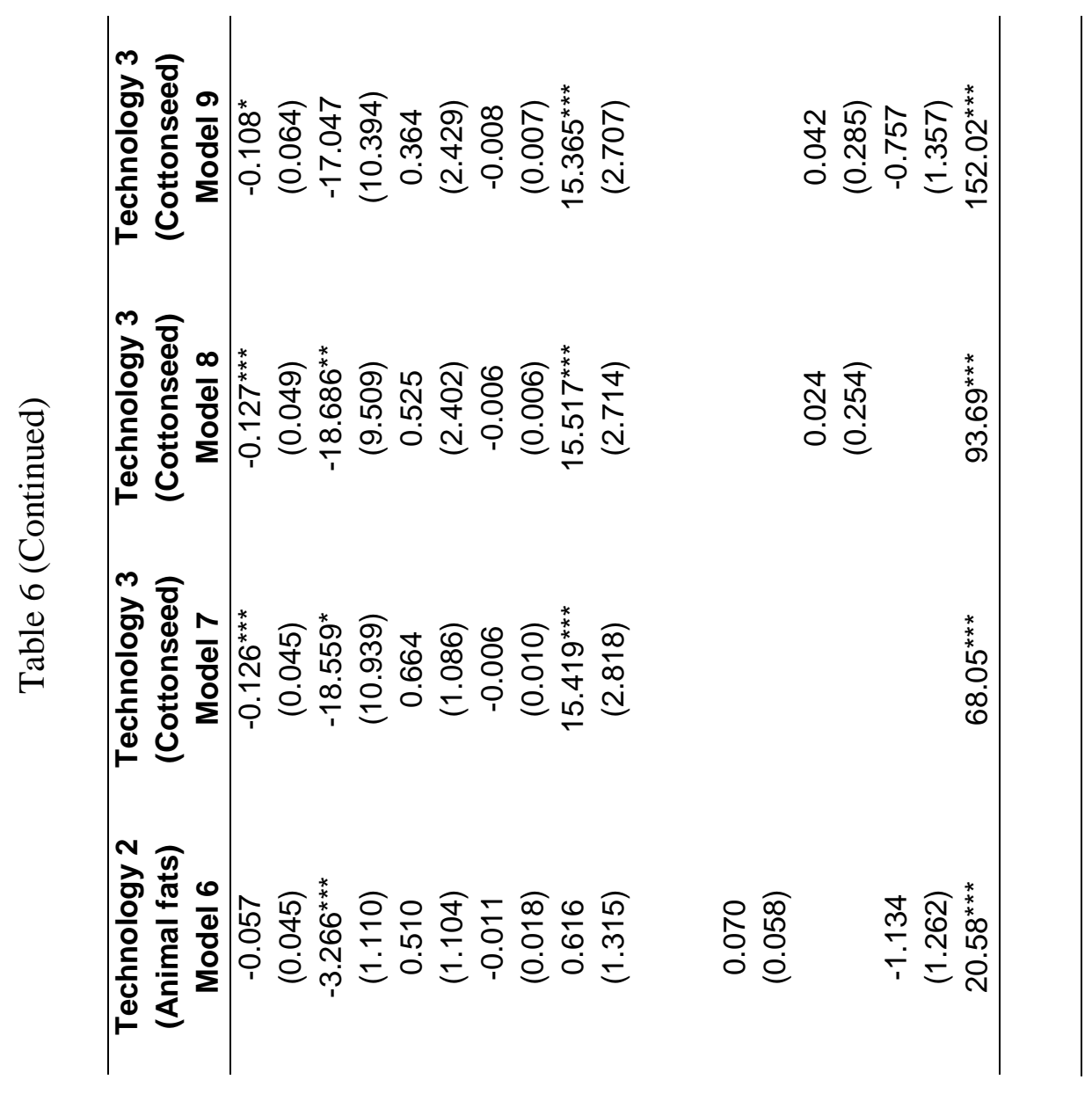


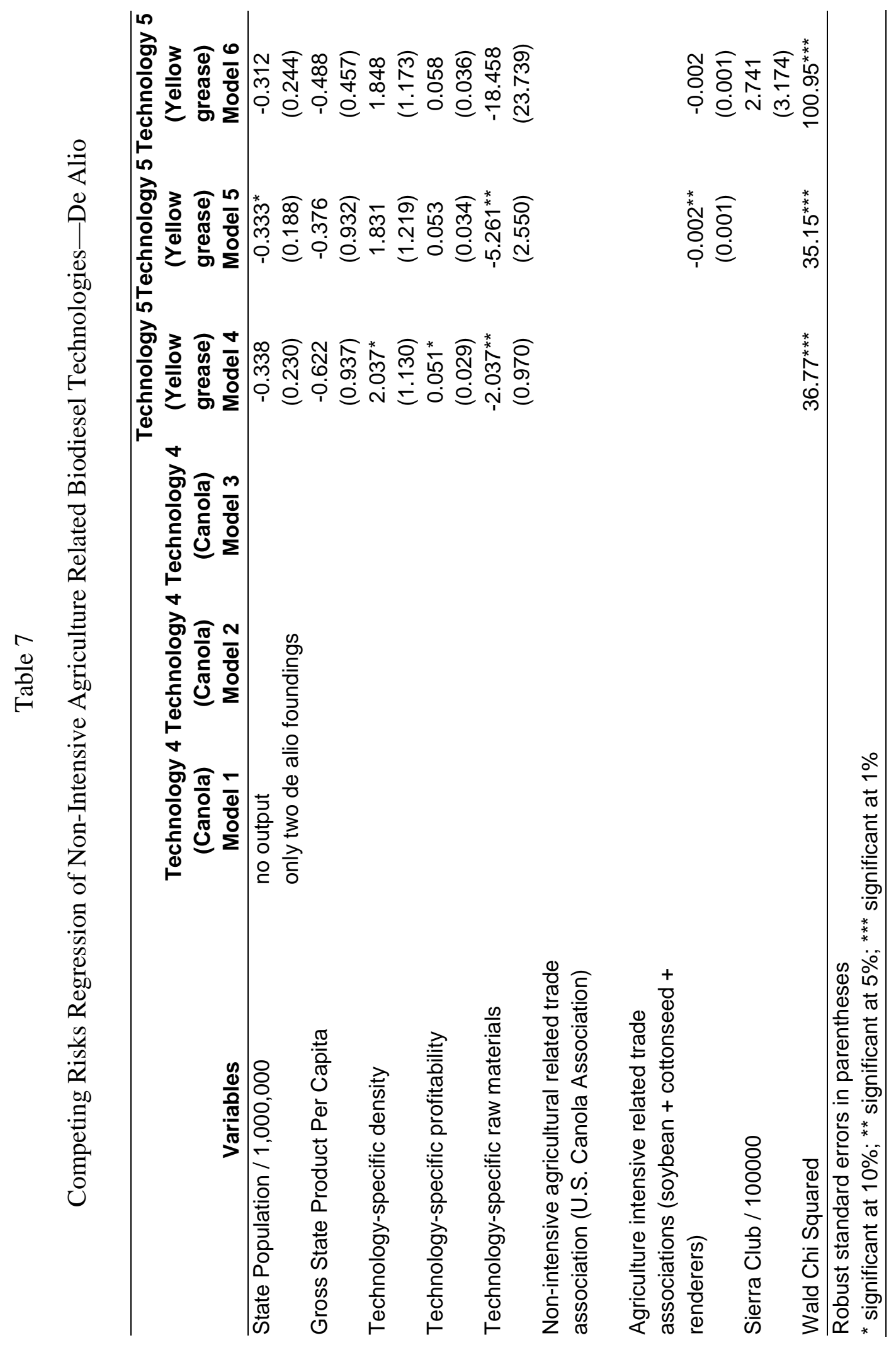


In table 2, models 1, 5 and 9 contain only the control variables; models 2, 6 and 10 add the strength of a particular institutional actor (agriculture trade association) promoting a certain technology as measured by its membership; models 3, 7, and 11 add the impact of competing actors as measured by Sierra Club membership; and models 4, 8, and 12 include the interactions between trade association and Sierra Club actors. Some of the control variables significantly impacted technological choice. For example, in many of the technological choices, the availability of raw materials specific to that technological process and the technological density had a positive impact on the adoption of that technology, consistent with prior expectations. States with lower gross state product per capita also had a positive effect on the choice of agriculture-intensive related technologies.

In table 3, models 1 and 5 contain the control variables; models 2 and 6 include trade associations promoting non-intensive agriculture related (canola) and agriculture-intensive related technologies (soybean, cottonseed, and animal fats), respectively; models 3 and 7 include state Sierra Club membership; and models 4 and 8 adds the interaction Sierra Club membership and agricultural trade associations. Similar to adoption of agriculture-intensive related technologies, raw material availability and technological density had positive impacts on the adoption of nonintensive agriculture related technologies.

Turning hypotheses 1, 2 and 4, in tables 2 and 3 the strength of a specific trade association generally had a positive effect on the adoption of that particular technology at founding, thus supporting hypothesis 1. A greater presence of soybean, renderers, canola, and cottonseed agriculture trade associations promoting their specific biodiesel technologies positively impacted entrepreneurial adoption of those processes. Additionally, the results indicate that a greater presence of Sierra Club who opposed biodiesel technological processes related to intensive agricultural practices 
had a negative impact on the adoption of those technologies and a positive effect on the adoption on non-intensive agricultural related technologies, thus supporting hypotheses $2 \mathrm{a}$ and $4 \mathrm{a}$ respectively. However, the interaction between incongruent values and beliefs of Sierra Club actors and promoted technologies did not have a significant dampening effect on the influence of agricultural trade associations, revealing little support for hypothesis $2 \mathrm{~b}$.

Hypothesis 4b posited that the congruence between the values and beliefs of Sierra Club actors and the technologies promoted by trade associations will have an amplifying effect on the influence of trade associations. In model 4 of table 3 , the results demonstrate that trade associations promoting non-intensive agriculture related technologies such as canola transesterification ${ }^{4}$ have the greatest effect in environments where there are greater numbers of Sierra Club members, thereby supporting hypothesis 4b. In hypothesis 3, I argue that a blending effect will occur in areas where trade association actors promote prescriptions and understandings that are incongruent with promoted values and beliefs of the Sierra Club. The results in model 8 of table 3 support this hypothesis. Incongruence among cognitions motivates entrepreneurs to develop and adopt novel non-intensive agriculture related technologies that transform raw materials such as waste vegetable oil (yellow grease).

Turning to tables $4-7$, models 1 , 4 , and 7 contain the control variables for each technological process; models 2, 5, and 8, add the trade association promoting a specific technology as measured by membership; and models 3, 6, and 9 add the impact of Sierra Club members. For tables 4 and 5, the results indicate that the strength of an institutional actor promoting new prescriptions and information has a

\footnotetext{
${ }^{4}$ The Sierra Club stated that biodiesel made from "recurring oil-seed crops such as canola, which can be grown as part of regular crop rotation cycles without intensive water use" are less damaging to the environment than other traditional agriculture products (Sierra Club, 2007).
} 
significant positive effect on technology implementation among de novo entrants, thus supporting hypothesis 5a. Greater numbers of soybean, renderers, cottonseed, and canola trade associations fostered greater adoption of that particular technology among de novo than de alio ventures. Additionally, greater numbers of Sierra Club activists negatively reduced the adoption of one of the intensive agricultural related technologies among de novo entrants, thus offering partial support to hypothesis 5b. The choices of de alio entrepreneurs were less likely to be affected by the presence of either focal or competing institutional actors than their de novo counterparts.

\section{Discussion}

In this paper, I examined how competing institutional actors and network relations can moderate the influence of focal institutional actors in changing entrepreneurial cognitive and normative understandings. The results show that the impact of promoted prescriptions and information was moderated by competing institutional actors and the network relations of entrepreneurial firms. Competing institutional actors had both a magnifying and blending effect on focal actor influence. When promoted technologies were in harmony with the Sierra Club’s prescriptions and understandings, trade association actors had an amplified effect on technological choice and foundings. However, when technologies were incongruent with the prescriptions and cognitions of the Sierra Club, a blending effect occurred in which promoted technologies and practices caused entrepreneurs to seek out and develop new technologies that would fit their environmental beliefs and values.

Additionally, the results demonstrate that de alio entrepreneurs were less likely than de novo entrepreneurs to be influenced by trade association or Sierra Club actors to found a firm using a specific promoted technology. Strong ties to organizations and individuals in other cultural and economic contexts cause de alio entrepreneurs to be less concerned about conforming to norms and values of the focal environment or 
those promoted by institutional actors. Thus, entrepreneurial embeddedness had a dampening effect on the influence of institutional actors on entrepreneurs.

This paper makes several theoretical contributions. First, much of the past research at the nexus of institutions and entrepreneurship has focused on one actor endorsing a single organizational practice, when in the institutional environment there are typically many types of actors promoting many different kinds of practices and technologies among a host of possibilities, exerting many different pressures on organizations (Weber, Heinz, and DeSoucey, 2008; Hiatt, Sine, and Tolbert, 2009; Sine and Lee, 2009). Little is known about how competing actors promoting various practices and technological designs can affect entrepreneurial decision-making at the beginning of new sectors and technological lifecycles. This study contributes to this research by showing that opposition actors can moderate the influence of focal institutional actors by magnifying or by blending their influence, thereby affecting new ventures in unintentional ways.

Second, the results contribute to the technology entrepreneurship literature which is concerned how new technologies develop and diffuse over time (Tushman and Anderson, 1986; Rosenbloom and Christensen, 1994) Organizational scholars acknowledge the influence of institutional actors on new technology adoption, yet much of this work as focused on the entrepreneurial adoption of the promoted technologies (Garud, Jain, and Kumaraswamy, 2002; Hargrave and Van de Ven, 2006; Sine, Haveman, and Tolbert, 2005) and has neglected how moderating forces in the institutional environment can transform institutional actor influence into a source of innovation. Building on past research, this paper finds that the promotion of existing technologies by institutional actors can also be the impetus behind new technology development when promoted prescriptions and understandings conflict with values and interests promoted by competing actors. 
Third, few empirical studies have analyzed how the effectiveness of institutional actors can be moderated by the characteristics of their targets. Much of the literature assumes that organizations and entrepreneurs are affected by promoted prescriptions and scripts equally, and largely overlooks the role of industry structure, social ties, or cultural backgrounds in impacting targets' perceptions of new values and information. Unlike prior work, this study probes how structural embeddedness can affect entrepreneurial entrants' propensity to be influenced by the culturalcognitive promotions of institutional actors. While my analysis considers the moderating effects of peripheral relational and cultural contexts, it does not address how other characteristics such as an entrepreneur's previous work experience (Burton, Sorenson, and Beckman, 2002; Phillips, 2002), educational background (Shane, 2000), or personality may affect a target's disposition of influence. Research that investigates the moderating effects of individual characteristics on the ability of institutional actors to instigate change is needed.

Finally, this paper is not without its limitations. For example, while I use de alio entrepreneurs to measure ties to outside organizations, I do not measure how other kinds of ties may influence the effectiveness of institutional actors. It is possible that a more in-depth analysis at entrepreneurial embeddedness may provide more nuanced effects such as magnifying or blending, instead of just a dampening as the results of this study indicate. Research on how the variety of entrepreneurial ties on founder decision-making is warranted. 


\section{REFERENCES}

Baker, T. \& Nelson, R. E. 2005. Creating something from nothing; Resource construction through entrepreneurial bricolage. Administrative Science Quarterly, 50: 329-366.

Burton, M. D., Sorensen, J. B., \& Beckman, C. 2002. Coming from good stock: Career histories and new venture formation. Social Structure and Organizations, 19: 229-262.

Carroll, G. R., Bigelow, L. S., Seidel, M.-D., \& Tsai, L. B. 1996. The fates of de novo and de alio producers in the American automobile industry 1885-1981. Strategic Management Journal, 17: 117-137.

Carroll, G. R. \& Hannan, M. T. 2000. The Demography of Corporations and Industries. Princeton, NJ: Princeton University Press.

Cohen, J. \& Cohen, P. 1983. Applied Multiple Regression/Correlational Analysis for the Behavior Sciences. Hillsdale, NJ: Lawrence Erlbaum.

Davis, G. F. \& Greve, H. R. 1997. Corporate Elite Networks and Governance Changes in the 1980s. American Journal of Sociology, 103: 1-37.

DiMaggio, P. J. 1988. Interest and agency in institutional theory. In L. G. Zucker (Ed.), Institutional Patterns and Organizations: Culture and Environment: 3-21. Cambridge, MA: Ballinger. 
Dowell, G., Swaminathan, A., \& Wade, J. 2002. Pretty pictures and ugly scenes: Political and technological maneuvers in high definition television. Advances in Strategic Management, 19: 97-133.

Emirbayer, M. \& Mische, A. 1998. "What is agency?" American Journal of Sociology 103: $962-1023$.

Fargione, J., Hill, J., Tilman, D., Polasky, S., \& Hawthorne, P. 2008. Land clearing and the biofuel carbon debt. Science, 319: 1235-1238.

Fine, J. P. \& Gray, R. J. 1999. A proportional hazards model for the subdistribution of competing risk. Journal of the American Statistical Association, 94: 496-509.

Friends of the Earth. 2008. Agrofuels: Fuelling or Fooling Europe? London, UK. February briefing.

Garud, R., Jain, S., \& Kumaraswamy, A. 2002. Institutional entrepreneurship in the sponsorship of common technological standards: The case of Sun Microsystems and Java. Academy of Management Journal, 45(1): 196-214.

Garud, R. \& Rappa, M. A. 1994. A socio-cognitive model of technology evolution: The case of cochlear implants. Organization Science, 5(3): 344-362.

Greenwood, R. \& Suddaby, R. 2006. Institutional entrepreneurship in mature fields: The big five accounting firms. Academy of Management Journal 49: 27-48.

Gooley, T. A., Leisenring, W., Crowley, J., \& Storer, B. E. 1999. Estimation of failure probabilities in the presence of competing risks: New representations of old estimators. Statistics in Medicine, 18: 695-706. 
Hannan, M. T. \& Freeman, J. 1977. The population ecology of organizations. American Journal of Sociology, 82: 929-964.

Hargrave, T. J. \& Van de Ven, A. H. 2006. A collective action model of institutional innovation. Academy of Management Review, 31(4): 864-888.

Haveman, H. A., Rao, H., \& Paruchuri, S. 2007. The Winds of Change: The Progressive Movement and the Bureaucratization of Thrift. American Sociological Review, 72(1): 117-142.

Hiatt, S. R., Sine, W. D., \& Tolbert, P. T. 2009. From Pabst to Pepsi: The deinstitutionalization of social practices and the creation of entrepreneurial opportunities. Administrative Science Quarterly, 54: 635-667.

Katila, R. and S. Shane 2005. When does Lack of Resources make New Firms Innovative? Academy of Management Journal 48(5): 814-829.

Lee, B. H. 2009. The infrastructure of collective action and policy content diffusion in the organic food industry. Academy of Management Journal, 52: 1247-1269.

Lounsbury, M. (2007). A tale of two cities: Competing logics and practice variation in the professionalizing of mutual funds. Academy of Management Journal 50(2): 289307.

Maguire, S., Hardy, C., \& Lawrence, T. B. 2004. Institutional entrepreneurship in emerging fields: HIV/AIDS treatment advocacy in Canada. Academy of Management Journal 47(5): 657-679. 
Marquis, C. \& Lounsbury, M. 2007. Vive la resistance: Competing logics and the consolidation of U.S. community banking. Academy of Management Journal, 50: 799820.

McKendrick, D. G., Jaffee, J., Carroll, G. R., \& Khessina, O. M. 2003. In the bud? Disk Array Producers as a (Possibly) Emergent Organizational Form. Administrative Science Quarterly, 48(1): 60-93.

Meeker, D. L. 2006. Essential Rendering. Arlington, VA: Kirby Lithographic Company.

Meyer, J. W. \& Rowan, B. 1977. Institutionalized organizations: Formal structure as myth and ceremony. American Journal of Sociology, 83(2): 340-363.

Orlikowski, W. J. 1992. The duality of technology: Rethinking the concept of technology in organizations. Organization Science 3(3): 398-427.

Pachter, A. 2007. Greenpeace opposing Neste palm-based biodiesel. The Epoch Times.

Phillips, D. J. 2002. A genealogical approach to organizational life chances: The parent-progeny transfer and Silicon Valley law firms, 1946-1996. Administrative Science Quarterly, 47: 474-506.

Pinch, T. J. \& Bijker, W. E. 1984. The social construction of facts and artefacts: Or how the sociology of science and the sociology of technology might benefit each other. Social Studies of Science, 14: 399-441. 
Rao, H., Davis, G. F., \& Ward, A. 2000. Embeddedness, social identity and mobility: Why firms leave the NASDAQ and join the New York Stock Exchange. Administrative Science Quarterly, 45(2): 268-292.

Rao, H., Morrill, C., \& Zald, M. N. 2000. Power plays: How social movements and collective action create new organizational forms. Research in Organizational Behavior, 22: 237-281.

Rosenbloom, R. S. \& Christensen, C. M. 1994. Technological discontinuities, organizational capabilities, and strategic commitments. Industrial and Corporate Change, 3: 655-685.

Saville, D. \& Wood, G. 1991. Statistical Methods: The Geometric Approach. New York: Springer-Verlag.

Schneiberg, M., King, M., \& Smith, T. 2008. Social movements and organizational form: Cooperative alternatives to corporations in the American insurance, dairy, and grain industries. American Sociological Review, 73(4): 635-667.

Scott, R. 2008. Lords of the dance: Professionals as institutional agents. Organization Studies, 29(2): 219-238.

Scott, W. R. \& Backman, E. V. 1990. Institutional theory and the medical care sector. In S. S. Mick (Ed.), Innovations in Health Care Delivery: Insights for Organization Theory. San Francisco: Jossey-Bass.

Shane, S. 2000. Prior Knowledge and the Discovery of Entrepreneurial Opportunities. Organization Science, 11(4): 448. 
Sierra Club. 2000. Sierra Club Conservation Policies: Biomass Guidance. San Francisco, CA: Sierra Club.

Sierra Club. 2007. Energy: Biofuels. Retrieved July 2008, from http://oregon.sierraclub.org/tracker/SB2210.html.

Sine, W. D., Haveman, H. A., \& Tolbert, P. S. 2005. Risky Business?

Entrepreneurship in the New Independent-Power Sector. Administrative Science Quarterly, 50(2): 200-232.

Sine, W. D. \& Lee, B. H. 2009. Tilting at windmills? The environmental movement and the emergence of the U.S. wind energy sector. Administrative Science Quarterly, 54: 123-155.

Stephens, T. 2008. Phone interview with Todd Stephens. Ithaca, NY.

Suchman, M. C. 1995. Managing legitimacy: Strategic and institutional approaches. Academy of Management Review, 20(3): 571-610.

Swaminathan, A. \& Wade, J. 2001. Social movement theory and the evolution of new organizational forms. In C. B. Schoonhoven \& E. Romanelli (Eds.), The Entrepreneurship Dynamic in Industry Evolution: 286-313. Palo Alto, CA: Stanford University Press.

Thornton, P. H. 2001. "Personal versus market logics of control: A historically contingent theory of risk of acquisition." Organization Science 12 (3): 294-311.

Thornton, P. H. 2002. "The rise of the corporation in a craft industry: Conflict and conformity in institutional logics." Academy of Management Journal 45(1): 81-101. 
Tolbert, P. S. \& Zucker, L. 1996. The institutionalization of institutional theory. In S. R. Clegg \& C. Hardy \& W. R. Nord (Eds.), Handbook of Organization Studies: 175190. London: Sage.

Tushman, M. L. \& Anderson, P. 1986. Technological Discontinuities and Organizational Environments. Administrative Science Quarterly, 31(3): 439-465.

Van Gerpen, J., Pruszko, R., Clements, D., Shanks, B., \& Knothe, G. 2006. Building a

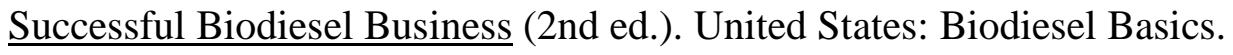

Vernet, J. 2005. An assessment of waste vegetable oil supply in Brooklyn, NY and its potential as a biodiesel feedstock. New York City: Cornell University Cooperative Extension. October 14, 2005.

Weber, K., Heinze, K. L., \& DeSoucey, M. 2008. Forage for thought: Mobilizing codes in the movement for grass-fed meat and dairy products. Administrative Science Quarterly, 53(3): 529-567.

Weick, K. 1990. Technology as equivoque. In P. Goodman \& L. Sproull (Eds.), Technology and Organizations. San Francisco, CA: Jossey-Bass. 


\section{CHAPTER 3}

\section{THE EFFECT OF INSTITUTIONAL ACTOR COMPETITION ON ENTREPRENEURIAL ACTIVITY IN THE U.S. BIODIESEL INDUSTRY}

\section{Introduction}

Entrepreneurship literature has generally focused on the effects of technological development in producing new markets and generating entrepreneurial activity (Schumpeter, 1934; Tushman and Anderson, 1986; Garud and Kumaraswamy, 1995; Rosenbloom and Christensen, 1994), and has largely ignored how social structure and cultural change can create new sectors and facilitate entrepreneurial exploitation. Recently, however, organizational scholars have begun to analyze how the actions of powerful institutional actors can create social structures that are conducive to entrepreneurs engaging in new types of economic activities (Rao, Morrill, and Zald, 2000; Swaminathan and Wade, 2001; Schneiberg, King, and Smith, 2008; Weber, Heinze, and DeSoucey, 2008; Hiatt, Sine, and Tolbert, 2009). ${ }^{5}$ By legitimating certain practices and resources within a field and lobbying for regulatory changes, researchers have noted how institutional actors can create opportunities for entrepreneurs to found new organizations such as bureaucratic thrifts, wind-power generation plants, and organic certifying agencies (Haveman, Rao, and Paruchuri, 2007; Sine and Lee, 2009; Lee, 2009).

\footnotetext{
${ }^{5}$ While there are many ways in which scholars have defined institutions and institutional actors, in this paper I define institutions as organizational forms, components, structures, or technologies that have become taken-for-granted as efficacious and necessary (Meyer and Rowan, 1977). I define institutional actors as individual or collective actors that promote organizational arrangements or structures in an effort to institutionalize them (DiMaggio, 1988; Tolbert and Zucker, 1996).
} 
For example, by successfully lobbying for the passage of renewable energy state tax credits, the Sierra Club helped produce the nascent renewable energy sector by facilitating foundings of wind-power producers and making the endeavors more profitable than they otherwise would be (Sine and Lee, 2009). Likewise, the Grange Alliance of the late nineteenth and early twentieth centuries facilitated the formation of human capital, networks, and commercial partnerships necessary for the emergence of new forms of insurance companies and dairy and grain-elevator cooperatives (Schneiberg, King, and Smith, 2008).

Although studies such as these have enhanced our understanding of how powerful actors can facilitate opportunity creation and exploitation, they largely evoke a "hero" image of one actor endorsing a single organizational practice, when in the institutional environment there are typically many types of actors promoting many different kinds of practices and technologies, exerting many different pressures on organizations. Little is known about how actors promoting competing practices and technological designs — or institutional actor heterogeneity_can affect entrepreneurial decision-making at the beginning of new sectors and technological lifecycles.

Yet, pluralistic pressures exerted by multiple actors may greatly affect entrepreneurial decision-making in emerging sectors and markets where many unproven technologies and practices exist and where standards and dominant designs are yet to be developed. In deciding to found a firm, entrepreneurs must choose among often uncertain technologies, trying to select ones in the long run will provide the greatest opportunity for organizational survival. For example, in the early years of the bicycle industry, entrepreneurs faced the difficult decisions of entering the unproven sector and then choosing a successful design when no dominant design or standard existed (Pinch and Bijker, 1984; Dowell and Swaminathan, 2006). Bicycle entrepreneurs could choose to adopt the British 'ordinary' models of the large front 
wheel, small rear wheel and direct pedal drive, or three other different (yet popular) designs including the safety bicycle that eventually became the dominant design. Thus, given the challenges related to emerging sectors and technologies, how do multiple institutional actors promoting distinct technologies or designs with numerous potential consequences affect entrepreneurial decision-making? Do they discourage or encourage foundings? Does the presence of a number of options encourage or discourage technological innovation and variation?

I address these questions by examining the impact of competing institutional actors on entrepreneurial founding rates and technological variation in the U.S. biodiesel industry. Empirically, I explore how multiple agriculture trade associations promoting specific biodiesel technologies related to their industry can alter the cultural-cognitive environment and influence new-venture foundings, innovation and diversity in the biodiesel market from 1990 through 2008.

\section{Biodiesel industry}

The biodiesel sector presents an ideal context in which to study the effect of actor heterogeneity on entrepreneurial activity. Biodiesel is fuel derived from a variety of organic sources for use in compression-ignition (diesel) engines. Typical feedstock oil includes soybean and canola oils, beef and pork tallow, and fryer oil from restaurants. Once oil is extruded from oil-seed plants, rendered from animal carcasses, or siphoned from restaurant grease traps, it undergoes a transesterification process in a biodiesel production facility where, through varying technologies individualized for each kind of extracted oil, glycerol is removed from triacylglycerol (triglyceride) leaving alkyl esters, resulting in a liquid compound that has properties similar to petroleum distillates used to power diesel engines. The type of fats and oils used as feedstocks determines the type of chemical and mechanical process or technological design. For example, many refined vegetable oils have low percentages of free fatty 
acids whereas crude vegetable, animal tallow, and recycled vegetable oils contain more free fatty acids and phospholipids as well as other contaminants that must be dealt with using specific chemical processes before customized transesterification processes can take place (Van Gerpen, Pruszko, Clements, Shanks, and Knothe, 2006). Thus, the technological design used to process, for example, soybeans is different from that used to process, for example, poultry fats.

The technology to make biodiesel came about through a series of improvements in soap-making technology. Early raw materials for soap production included corn oil, peanut oil, hemp oil, and animal tallow. However, the alkyl esters formed using the soap-making process in the $19^{\text {th }}$ century were highly contaminated with potassium soaps and discarded. The transesterification technology used today to produce alkyl esters (biodiesel) is based on techniques developed by chemists at DuPont and Colgate-Palmolive-Pete during World War II. Soap and chemical companies at the time received government contracts to produce pure glycerin, a component of explosives, and the alkyl esters continued to be largely discarded (Van Gerpen, Pruszko, Clements, Shanks, and Knothe, 2006). Interest in transesterification technology largely waned after WWII the United States, although researchers continued to develop an understanding of the underlying chemical process, attention to the potential uses of the technology and in particular to alkyl esters in generating fuel commenced after the oil shocks of the 1970s in universities.

Yet, the use of vegetable oil as an engine fuel is not new. It traces its beginnings with the invention of the diesel engine. In 1897, Rudolph Diesel successfully created a prototype of the world's first "heat" engine that ran without spark. While the first prototypes ran mostly on petroleum distillates, Diesel spent the latter part of his life tweaking successive models to run on pure vegetables oils and promoting the use thereof. He said: “The use of vegetable oils for engine fuels may 
seem insignificant today, but such oils may become, in the course of time, as important as petroleum and the coal-tar products of the present time....Motor power can still be produced from the heat of the sun, always available, even when the natural stores of solid and liquid fuels are completely exhausted” (Diesel, 1913: 1605). However, Diesel's untimely death in 1913 and the growing abundance of cheap petroleum fuel largely ended research on vegetable-oil fuels.

It was not until the late 1970s, as oil prices sky rocketed and fuel shortages loomed, that government agencies and academic researchers again began investigating vegetable oil as potential fuel source. Starting in 1979, a number of academics such as Dr. Charles Peterson at the University of Idaho and Dr. Leon Schumacher at the University of Missouri began conducting vegetable oil alkyl-ester experiments in diesel engines. Despite the ample amount of research and development performed at the university level, the biodiesel industry may never have developed as it has today without the channeling of entrepreneurial attention to this new organizational form by agriculture trade associations. Because trade associations are always looking for opportunities to expand the market for their member firms, once they discover a new use for their products, they proceed to promote those new applications using a number of tactics to legitimate the new product use.

In 1990, the Missouri Soybean Association, found out about the alkyl ester research being conducted in Dr. Schumacher's lab at the University of Missouri. When the association learned that Schumacher was trying to make a biodiesel out of grape seed oil, association members contacted him and suggested that he try using soybean oil instead. Schumacher consented, and the Missouri Soybean Association began sponsoring his research. After a number of successful soybean alkyl-ester tests, the Missouri Soybean Association began promoting the soybean alkyl-ester 
technology developed in Dr. Schumacher's laboratory as the production technology entrepreneurs should adopt when founding a biodiesel refinery.

Other agriculture industry associations learned of other types of plant and animal oils that could serve as raw materials for biodiesel and also entered the fray, seeking out and sponsoring university research, and endorsing biodiesel production designs that utilized agriculture products harvested by their members. For example, the U.S. Canola Association endorsed technologies that used canola oil while the National Renderers Association drew attention to technologies that utilized animal tallow and the National Corn Growers Association advocated technologies that employed corn oil as a biodiesel raw material. State trade association members attended agriculture conferences, county fairs, and other public venues to discuss and demonstrate the new technology. After filling up buses, tractors, and trucks, with biodiesel, they would drive thousands of miles across county roads, garnering much attention. They would often bring university scientists to testify of the particular technology’s effectiveness and appropriateness.

Thus, while all the agriculture associations in this study shared a common concern with the biodiesel sector, they also promoted varying production technologies depending on the industry members they represented. Because the application of soapmaking technologies to biodiesel production was very new and entrepreneurs could not simply conduct a cost-benefit analysis of which technological production process they should adopt, the influence of agriculture trade associations promoting the "best" technology likely had a large influence on the decision of entrepreneurs to found a firm and to adopt or develop a production process.

\section{Institutional Actors and Entrepreneurial Decision-Making}

Entrepreneurs endeavoring to start an organization in a new sector with a variety of unproven technologies face a number of challenges. First, they must decide 
to enter into an emerging sector characterized by high uncertainty and little cognitive and sociopolitical legitimacy. Second, they are presented with the dilemma of choosing an uncertain technology that will have a long and successful trajectory. In every new technology cycle, eras of substitution and direct competition occur wherein emerging technologies vie to become the accepted market standard or dominant design (Abernathy and Utterback, 1978), with practices enjoying the greatest support among government, professions and other organizations becoming ascendant (Rao, 1998).

During the early-cycle period, entrepreneurs must sort through unproven practices and select or develop a technology that has the greatest probability of surviving the competition (Anderson and Tushman, 1990). After founding a firm and deciding on a technology, they face the challenge of convincing key constituents such as creditors, investors, suppliers, and buyers that their sector and product or service rendered from the new technology is appropriate and desirable. If the sector or technology lacks substantial cognitive and sociopolitical legitimacy, entrepreneurs will find it difficult to obtain the resources they need to start and grow their organization (Aldrich and Fiol, 1994; Suchman, 1995). Yet, given the high uncertainties regarding industries and technologies in the beginning of new markets, understanding the factors that impact entrepreneurs' decisions to start a firm and choose a technology may help better explain how multiple actors promoting various organizational practices and technologies may affect entrepreneurial activity.

Some scholars argue that an entrepreneur's decision to start a venture or choose a technology is highly rational, based on expected demands and potential profits, technology life cycle age, density of competitors, availability and cost of resources, and market demand (Schumpeter, 1934; Simon, 1947; Kirzner, 1973; Hannan and Freeman, 1977; Blau, 1987; Dunne, Roberts, and Larry, 1988; Evans and Jovanovic, 1989; Tushman and Anderson, 1986; Evans, 1989; Hayek, 1949). While 
these studies provide a foundation to understand how entrepreneurs make decisions, they largely fail to address how entrepreneurs make choices when faced with high uncertainty and information asymmetry, and they suggest a single-direction path in which individuals first decide to become entrepreneurs and then look for opportunities to make a profit, when the emergence of new opportunities could induce individuals to become entrepreneurs.

Other scholars assert that entrepreneurs make rationally bounded decisions and that unsettled and ambiguous circumstances can increase the influence of social structures on entrepreneurial decision-making (Simon, 1947; Sine, Haveman, and Tobert, 2005; Hargrave and Van de Ven, 2006). As uncertainty and lack of information increase, social structures can provide entrepreneurs with an automatic response to a variety of choices (Simon, 1947). For example, a number of sociological studies suggests that past education and research experiences (Shane, 2000) as well as previous employment environments (Burton, Sorensen, and Beckman, 2002; Phillips, 2002; Dobrev and Barnett, 2005; Sorensen, 2007) provide structures that shape entrepreneurs' cognition and choice of the type of form their new organization should take (Tolbert, David, and Sine, 2010). While these studies illustrate an important source of social structure, this approach ignores the fact that entrepreneurs do not always reproduce the kinds of organizations in which they were employed. Otherwise there would be little innovation or movement of entrepreneurs from one industry to another.

Another social influence recently explored by organizational scholars that can affect entrepreneurial decision-making is that of institutional actors (Swaminathan and Wade, 2001; Sine and Lee, 2009). In particular, highly endowed and organized individual or collective actors, such as professional associations, trade associations or social movement organizations can engage in institutionalization projects to promote 
the acceptance of a new practice or technology by diffusing information, advocating the passage of laws and regulations, and "framing issues and problems, and mobilizing constituencies" in an effort to "infuse new beliefs, norms, and values into social structures” (Rao, Morrill, and Zald, 2000: 240), resulting in the formation of new entrepreneurial opportunities, organizational forms, industries, or associated institutions (DiMaggio and Powell, 1983; DiMaggio, 1988; Lounsbury, 2001; Schneiberg, 2002). As institutional actors promote the adoption of new institutional beliefs, values, and regulations, they augment the cognitive and sociopolitical legitimacy of the emerging practice and shape individuals' understanding of the new technology, which can increase their inclination to exploit an opportunity and found a firm (Aldrich and Fiol, 1994; Sine, Haveman, and Tolbert, 2005).

\section{Actor Heterogeneity, Entrepreneurial Foundings and Technological Diversity}

One way institutional scholars have tried to explain institutional change and organizational heterogeneity has been by focusing on the collective mobilization of professions, social movement organizations, and other political actors as key players in enacting change (Greenwood and Suddaby, 2006; Scott, 2008; Weber, Heinz, and DeSoucey, 2008). These studies have largely explained organizational or practice variation as a result of actor strength, asserting that as a given institutional actor increases in power, so does its ability to influence the adoption or emergence of a specific practice or organizational form. By focusing on one actor promoting a single practice or form, they restrict practice variability to a binary outcome: organizations either implement the original practice or the new one. We know very little about how institutional actors can affect the emergence or adoption of multiple organizational forms or practices, which often characterize the early periods or ferment stage of the technological lifecycle. Moreover, studies that narrowly focus on a single institutional actor may overlook other actors that are contributing to changes in the cultural- 
cognitive environment. Hence, by studying actor heterogeneity we can increase our understanding of how competition among institutional actors can foment entrepreneurial activity and organizational heterogeneity.

A handful of studies have investigated how varying institutional logics or values impact organizations using empirical contexts such as universities (Albert and Whetten, 1985), public broadcasters (Powell, 1988), multi-national firms (Kostova and Zaheer, 1999), and banks (Marquis and Lounsbury, 2007). Many of these studies assert that organizations react to greater institutional pluralism by growing in size and adding additional administrative functions (Meyer and Rowan, 1977; Meyer and Scott, 1983). For example, in a study of U.S. telephone companies, Barnett and Carroll (1993) found that greater fragmentation of regulatory pressures from federal, state, and local laws increased the size of telephone companies as these organizations created structures to deal with the additional demands. Other studies have noted that some organizations facing complex environments react by creating customized identities for each constituent. For example, Kraatz and Block (2008) found that universities, facing pluralistic institutional pressures from businesses and students, created multiple identities in an effort to maintain legitimacy but not without a cost. The multiple identities caused deep-rooted tensions among departments and faculty members. Nevertheless, these studies are limited in that they focus on traditional firms in established markets and overlook the efforts of multiple, competing institutional actors in producing institutional change at the beginning of new sectors and technology lifecycles.

In this study, I propose that the presence of diverse actors promoting different kinds of practices and technologies can have a significant effect on entrepreneurial activity and technological variation by appealing to a broad variety of individual tastes and their available resources. Regarding the first mechanism, individuals have varying 
tastes and values, and just as diversity among organizational forms generates greater appeal to diverse population segments (Sørensen and Sorenson, 2007), an assortment of promoted technologies and forms may resound with a greater variety of potential entrepreneurs leading to increased foundings. The recent growth of charter schools provides an example of how varying choices in organizational forms can appeal to different sets of entrepreneurs and provide opportunities for organizational emergence. Charter schools are publicly supported schools that are run privately and are based on various teaching philosophies such as military education, foreign language immersion, or whole child. The variety in pedagogy philosophies can motivate a broad range of entrepreneurs to found distinct charter schools espousing those viewpoints. For example, not long after Chicago allowed charter schools, between 1997 and 2008 over 67 different charter schools representing a variety of teaching philosophies were founded (Brown and Gutstein, 2009).

Second, individuals have access to different sets of resources, which can affect their decision to found a firm. Education, social networks, and prior experiences affect access to knowledge, capital, and the kinds of employees they can hire. For example during the emergence of the automobile industry, technologies related to steam, coal gasification, electricity, and petroleum provided opportunities for entrepreneurs familiar with and/or had access to such technologies and resources to found firms and produce automobiles that were propelled using a variety of these locomotive technologies (Eckermann, 2001). Additionally, in the electricity generation sector, many of the entrepreneurs who started wind-power facilities after the industry became deregulated did so because wind technology appealed to their environmental values and complemented their educational background in mechanical engineering (Sine and Lee, 2009). 
In the context of the U.S. biodiesel sector, in areas where a heterogeneous group of institutional actors such as agriculture trade associations promote soybean feedstock technologies as well as poultry fat feedstock technologies, both individuals who have an affinity towards and/or have access to soybeans and those who are drawn to the idea of using animal rendered products and/or have access to those raw materials and technologies may be enticed to become entrepreneurs and found new firms. An example of this is Earl-Fisher biofuels of Montana. While the founders had heard about biodiesel before, it wasn't until they were exposed to the promotion of canola oil feedstock technologies at a farmer's union conference that Brett Earl and Logan Fisher became excited to found a firm and began making plans for their facility. Their motivation was based largely on the fit of the technology with Fisher's background-he was a canola farmer and thus had greater access and knowledge about this particular raw material than other kinds of oilseed crops. Another example is Agrifuels, LLC of Ohio. The founders related that they started a biodiesel facility that used soybean technologies because they believed that their customers who were primarily soybean farmers would rather buy biodiesel made from soybeans than any other kind of raw material.

In sum, because entrepreneurs espouse a variety of preferences and have access to different types of resources, the promotion and legitimation of diverse technologies at the beginning of new sectors and technological lifecycles should have a significant positive effect on new foundings. Consequently, as new ventures adopt a variety of promoted technologies, the technological variation in a given region should also increase. Thus, I argue:

Hypothesis 1: Biodiesel foundings will increase as the heterogeneity of competing trade associations increases. 
Hypothesis 2: Technological diversity among biodiesel foundings will increase as the heterogeneity of competing trade associations increases.

Yet, the effect of actor variation on new-venture foundings and technological diversity may be moderated by the strength or size of the institutional actors involved. Past research suggests that the more powerful the actors, the greater the influence they will have on individuals and organizations to adopt the promoted technology or practice (Pfeffer and Salancik, 1978; Lounsbury, 2001; Sine and Lee, 2009). For example, Schneiberg and colleagues (2008) found that greater numbers of Grange members in a given state increased the anti-corporate movement's power and ability to change cultural values and beliefs regarding organizational forms, thereby leading to greater foundings of cooperatives. Likewise, Hiatt and colleagues (2009) found that greater numbers of Woman’s Christian Temperance Union members in a given state increased the temperance movement's ability to deinstitutionalize the consumption of alcohol, thereby leading to greater brewery failures. Because actor strength has been shown to be positively correlated with their ability to change cultural and cognitive beliefs, I propose that the impact of institutional actor heterogeneity on entrepreneurial activity and technological variation will be amplified by the strength or size of the total actors of interest.

Hypothesis 3: The impact of trade association heterogeneity on biodiesel foundings will be positively moderated by the net size (strength) of the trade associations promoting different technologies.

Hypothesis 4: The impact of trade association heterogeneity on technological variation will be positively moderated by the net size (strength) of the trade associations promoting different technologies. 


\section{Actor Heterogeneity and Development of Innovative Technologies}

At the same time, institutional actor heterogeneity may also impact the entrepreneurs' decision of either adopting a promoted technology or choosing to combine technologies, thereby creating a novel, proprietary technological process. A number of early scholars suggested that complex environments characterized by conflicting cultures, ideas, values, and beliefs can function as a stimulus for creativity and innovation among organizations (Baldridge and Burnham, 1975). For instance, Coser (1957) argued that conflict exerts "pressure for innovation and creativity” and that the "clash of values and interests, the tension between what is and what some groups feel ought to be, the conflict between vested interests and new strata...[are] productive of vitality... and burst[s] of creativity” (197-198). Dewey (1930) stated that "conflict is the gadfly of thought. It stirs us to observation and memory. It instigates to invention. It shocks us out of sheep-like passivity, and sets us at noting and contriving....Conflict is a sine qua non of reflection and ingenuity” (300). Additionally, Powell (1991), asserted that “novel recombinations may occur” among “organizations located in complex environments, particularly those subject to both strong institutional and technological pressures” (199).

A number of historical accounts seem to support these theoretical assertions. For example, some historians argue that cross-cultural contact from the Christian Crusades was a source of innovation and a major impetus behind the renaissance and moving Western Europe out of the dark ages because it exposed knights to Arab beliefs and knowledge in mathematics, engineering, and physics. One writer noted:

The Crusades...re-established traffic between the East and West, which, after having been suspended for several centuries, was then resumed with even greater energy; they were the means of bringing from the depths of their respective provinces and introducing into the most civilized Asiatic countries 
Western knights, to whom a new world was thus revealed, and who returned to their native land filled with novel ideas.... The development of general culture in the West was the direct result of these Holy Wars (Brehier, 1907: 556).

Similarly, Galison (1997) has written how cooperative work among individuals from different intellectual backgrounds can foment creativity and innovation. He provides as an example how the collaboration between engineers and physicists-each of different subcultures, training, and expertise-produced theoretical propositions describing radar and later together created a functioning prototype of radar during World War II. In sum, while a number of theoretical and historical accounts provide strong evidence of a general relation between complex environments and innovation, there are very few empirical studies that demonstrate how fragmented environments can affect the kinds of technologies entrepreneurs will adopt or develop. Applying work by social psychologists may provide a fruitful framework of how institutional actors promoting differing ideas and fragmenting the cultural and cognitive environment can affect new-firm creativity and innovation.

Research in social psychology suggests that environments characterized by diverse concepts and values can encourage creative performance (Simonton, 1975) by exposing individuals to a broad range of views and ideas (Mendelsohn and Griswold, 1964; Toplyn and Maguire, 1991; Amabile, 1996; Kasof, 1997). Campbell (1960) noted that creativity results when an individual receives a wide variety of inputs and engages in a high rate of selectivity to decide which of the alternatives to retain. As individuals select certain inputs and evaluate them, they "bring into contiguity otherwise separate streams of mental activity" that can facilitate "the combinatorial leap which is generally described as the hallmark of creativity" (Mendelsohn, 1976: 366). Expounding further on this mechanism, Martindale explained: 
The more elements that a person can focus on simultaneously, the more likely that a creative idea will result. Why? Because the more elements that can be focused on, the more candidates there are for combinations. Thus, with two elements - $A$ and $B$ - in the focus of attention, only one relationship $-A B-c a n$ be discovered. With three elements-A, B, and $C$-there are three potential relationships- $A B, A C$, and $B C$ - to be discovered. With four elements, there are six potential relationships, and so on (1981: 372).

Consequently, as entrepreneurs are exposed to a variety of values, ideas, and practices, they may engage in greater concept selection, retention, and evaluation, leading to a recombination of ideas (Simonton, 1988), which, according to many technology scholars, can be the foundation for innovative practices (Gilfillan, 1935). For instance, Schumpeter observed that "innovation combines components in a new way, or that it consists in carrying out new combinations” (1939: 88). Likewise, Nelson and Winter stated that "the creation of any sort of novelty in the art, science, or practical life_-consists to a substantial extent of a recombination of conceptual and physical materials that were previously in existence” (1982: 130). Thus, as the heterogeneity of institutional actors promoting different concepts, values, and ideas increases, so should the rate of innovation among new ventures.

An example of how heterogeneity of actors can spur recombinatorial innovation is provided by Michigan Biodiesel. In sorting through and considering the many different promoted technologies, CEO John Oakley reported that the founding team decided to develop a technological process that combined soybean, sunflower and poultry fat feedstock technologies. Part of that process included designing proprietary batch-flow processes with multiple self-cleaning tanks in order to reduce 
contamination from varying raw materials and allow for a more precise and efficient transesterification (Oakley, 2007).

The founding of ECO Friendly Products in 2007 offers another example. Two partners decided to found a biodiesel company in their home-state of Texas. Because it was during a period in which institutional actor competition in the state was relatively high, they were exposed to many kinds of promoted technologies. After taking some time evaluating existing technologies, they developed an innovative technology that combined the feedstock technology of waste vegetable oil with a municipal waste gasification process. The result was an innovative recombinatorial technology that produced biodiesel composed of methyl esters and n-butanol. The added ingredient of butanol actually helped diesel engines burn cleaner and more efficiently than regular biodiesel.

As diverse institutional actors advocate different technologies and issues, the cultural-cognitive environment can become fragmented, providing entrepreneurs with a wide repertoire of technologies and values to retain and evaluate. Consequently, in areas where the competition of trade associations is high, entrepreneurs may engage more in evaluative and recombinatorial processes in an effort to find the technological design that is best suited for their firm, leading to the development of innovative combinatorial production capabilities. Thus I posit:

Hypothesis 5: Development of innovative recombinatorial technologies among biodiesel foundings will increase as the heterogeneity of trade associations promoting competing technologies increases.

The effect of actor heterogeneity on innovative recombinatorial technologies may also be moderated by the strength or size of the actors involved. Just as larger institutional actor size may translate into a greater ability to influence individuals and 
organizations (Sine and Lee, 2009; Hiatt, Sine, and Tolbert, 2009), greater size of the total competing actors may have a positive moderating impact on environmental complexity. The result of which may translate into more technological recombinations at the new-venture level. Thus,

Hypothesis 6: The effect of institutional actor heterogeneity on the development of recombinatorial technologies will be positively moderated by the net size (strength) of trade associations promoting different technologies.

\section{Methods}

In this study, I focus on the effects of institutional actor heterogeneity and strength on the emergence of new kinds of organizations and on technological adoption, innovation and diversity. Empirically, I measure the impact of competing agriculture trade associations on biodiesel foundings and technological variety. The window of observation is 1990 to 2008 . I use 1990 as the base year because that is the year that agriculture trade associations began sponsoring biodiesel university research and promoting such technologies and I end data collection on December 31, 2008. A total of 267 biodiesel production plants were founded during this period.

Dependent Variables. The dependent variables for this study are state-level founding events of biodiesel producers, state-level founding events of biodiesel producers that innovatively recombined technologies, and the degree of technological diversity of newly founded firms in a given state-year. Data on biodiesel producers come from quarterly reports generated by the National Biodiesel Board as well as archival reports from individual producers. From this information I am able to measure when each biodiesel plant began and ceased operation, the total number of biodiesel plants operating in a state, their total production capacity, and the feedstock technology they used over time. 
I measured technological variation by using a Blau (1977) index as modeled by $\left(1-\sum \mathrm{pit}^{2}\right)$ where $\mathrm{p}$ is the proportion of biodiesel producers using a certain feedstock production technology in a state and year $t$, and $\mathrm{i}$ is the number of different types of technologies used by biodiesel producers in the state. There is a moderately high retooling cost associated with changing production feedstock technologies. On average, biodiesel producers that had the resources to change technological designs in order to utilize other kinds of raw materials were forced to idle their plants for about a year. Because of this, entrepreneurs are highly motivated to pick the best production design from the start. A total of twenty-three different biodiesel production technologies were developed and adopted by biodiesel producers over the eighteenyear time period. I measured combinatorial technological innovation by indicating whether the producer was founded with an innovative recombinatory technology within a given state.

Key Predictor Variables. Agriculture trade associations promoted new organizational forms and technologies based on the belief that as entrepreneurs founded biodiesel facilities and adopted technologies that required organic feedstocks, they would boost demand and increase commodity prices of the agricultural products their members produced. I contacted all agriculture trade associations that represent producers of organic oils in the United States to find out whether they had promoted biodiesel. Six trade associations reported to have actively promoted biodiesel, namely, the American Soybean Association, National Renderers Association, United States Canola Association, National Corn Growers Association, National Sunflower Association, and the National Cottonseed Producers Association. Because many of these organizations are federative in nature, the state chapters are free to decide when and what they will promote. I contacted every state and national organization and obtained information on their membership, the dates of when the state chapters and 
national organizations began endorsing biodiesel as well as information on the promotion tactics they used. Because information on promotion tactics was limited, I left them out of the analysis.

I captured the effect of greater trade association competition in a state on biodiesel foundings, technology diversity among new foundings, and innovation by using a Blau (1977) heterogeneity index. Because heterogeneity measures the size or strength of a particular trade association in relation to other competing associations, the more equal in size and strength (i.e. greater heterogeneity), the more entrepreneurs will be exposed to varying promoted ideas and technologies at an equal rate. In contrast, greater trade association homogeneity may result in a dominant promoted technology that could muffle any competitive technologies. The variable is modeled as $\left(1-\sum \mathrm{pi}^{2}\right)$ where $\mathrm{p}$ is the proportion of members of a trade association, and $\mathrm{i}$ is the number of different kinds of trade associations represented in the state in year t. ${ }^{6}$ Thus, a score of 1 would denote perfect heterogeneity while a score of 0 would indicate perfect homogeneity.

Control Variables. I controlled for gross state product per capita, state population density, and acres of farmland density. Information on state population comes from the U.S. Census Bureau, while data on gross state product and acres of farmland are obtained from the U.S. Departments of Commerce and Agriculture, respectively. I also controlled for the amount of relevant human capital by calculating the number of people in each state employed in technical fields relevant to biodiesel technology. Biodiesel production requires various types of knowledge related to the chemistry and chemical engineering fields. Using the SIC code as a guide, I included employment data on chemists and chemical engineers from the Covered Employment

\footnotetext{
${ }^{6}$ I also created a count variable by summing the total number of trade associations in a given state and year and found similar results.
} 
and Wages Program compiled by the U.S. Bureau of Labor Statistics. Once the two major field variables were interpolated, I added the number of workers in these two groups by state to obtain the aggregate number of technical workers with skills and knowledge relevant to biodiesel production.

Because local access to biodiesel raw materials can affect the decision of entrepreneurs to found a biodiesel plant (Baker and Nelson, 2005; Sine and Lee, 2009), I controlled for the total amount of locally available raw materials and their price by summing the total pounds of animal fats, plant oils and waste vegetable oil (yellow grease) produced by state. I calculated the pounds of rendered animal fats by taking the pounds of pigs, cattle, and poultry slaughtered by state and computing the average percent of rendered fat per animal as determined by the National Renderers Association (Meeker, 2006). I calculated the amount of plant oils by summing the total bushels of sunflower, safflower, canola, rapeseed, soybean, corn, peanuts, cottonseed, and flaxseed harvested in a state and computing the average pounds of oil derived from each type of seed as determined by the United States Department of Agriculture's (USDA) National Agricultural Statistical Service. The data reveal the annual amount of crops harvested and animals slaughtered and the commodity prices for each type of oil and fat by year. As a measure of the pounds of waste vegetable oil produced by state, I counted the total number of food establishments per state and multiplied this by 372 pounds per month, the average amount of waste vegetable oil discarded by a restaurant (Vernet, 2005). The number of food service establishments comes from the U.S. Census Bureau’s Economic Census.

Because diversity of raw materials as well as the price could affect technological diversity of new ventures as well as the development of innovative recombinatorial technologies, I controlled for the heterogeneity of locally available raw materials by constructing a Blau index variable of the following locally available 
oilseed crops as mentioned above in a state: sunflower, safflower, canola, rapeseed, soybean, corn, peanuts, cottonseed, flaxseed, animal fats, and waste vegetable oil. Following previous research (Carroll and Hannan, 2000), I included a measure of industry age as the time since the first biodiesel refinery was founded.

Prior studies have found that organizational density can affect the amount of available resources and thereby influence new-venture foundings and the propensity to innovate (Hannan and Freeman, 1977; Katila and Shane, 2005). As such, I controlled for competition by summing the number of operating biodiesel plants in each state by year. I also controlled for state regulatory environment by constructing two variables that capture state biodiesel production mandates and biodiesel-specific production incentives. I measured state biodiesel production mandates and production incentive laws by placing a " 1 ” if a state had in place production mandates or incentive laws and “0” if it did not. Production mandates included state laws that mandated a certain percentage of biodiesel be produced in a state and blended with petroleum fuel at local gas pumps. Incentive policies included state tax credits for biodiesel production, state grants for the construction of biodiesel refineries, biodiesel blending credits, and reduced excise tax on biodiesel sales. Following previous studies, I also controlled for spillover effects of biodiesel density and regulation in surrounding states by creating variables that captured the total number of biodiesel plants in operation and the proportion of surrounding state mandates and state incentives (Wade, Swaminathan, and Saxon, 1998). I obtained data on these policies from U.S. Department of Energy’s Alternative Fuels and Advanced Vehicles Data Center (1990-2008) and from federal and state code books.

Given that profitability can affect the decision of entrepreneurs to adopt a particular technological process, I controlled for profitability in the models of founding, technological innovation and diversity by taking the average price of retail 
diesel sold in a state and subtracting it from the sum of the average cost of labor, capital, and chemical transesterification costs (methanol), and the annual average price of biodiesel raw materials per gallon using a weighted index score of feedstock spot prices recorded by the USDA's National Agricultural Statistical Service. I obtained data on state average retail diesel prices from U.S. Department of Energy and information on the average cost of labor and capital from reports from biodiesel analysts (Van Gerpen, Pruszko, Clements, Shanks, and Knothe, 2006).

I also controlled for the 2005 federal subsidy of biodiesel using a dummy variable in the founding and technology innovation and diversity analyses. This subsidy provided a tax credit of $\$ 1.00$ per gallon for technologies that transformed oilseed crops into biodiesel and $\$ .50$ per gallon for technologies that transformed animal fats and yellow grease into biodiesel for the years 2005 through 2008. I also controlled for biodiesel potential demand by calculating the amount of diesel consumption. These data came from the U.S. Department of Energy.

Finally, I supplemented archival data with thirty-two interviews with biodiesel founders and twenty-six interviews with agriculture trade associations and environmental movement organization members across the nation. The interview data grounded my choice of measures and strengthened my understanding of hypothesized structural relationships.

\section{Analysis}

To test the relationship between institutional actor heterogeneity and the rate of entrepreneurial activity (founding events) and recombinatorial technology founding events by state, I used a piece-wise exponential hazard model, thereby maximizing the use of available information (Carroll and Hannan, 2000). This analysis does not require strong parametric assumptions of a constant failure over rate the model's time 
span but allows the hazard rate to change at multiple intervals, allowing for greater flexibility (Blossfeld and Rohwer, 1995). The model has the general form of:

$$
\mathrm{r}(\mathrm{t})=\exp \left(\alpha_{i}+\beta \alpha\right)
$$

where $\alpha_{l}$ is a constant coefficient associated with the ith time interval, $\beta$ is a row vector of covariates and $\alpha$ is an associated vector of coefficients. I estimated the piecewise failure model with period effects in roughly five-year intervals (1990-1994, 1995-1999, 2000-2004, and 2005-2008). I chose five-year time periods because I felt it was best at approximating changes in the baseline rate as well as avoiding estimation problems that may occur from too few founding episodes within the time period (Blossfeld, Golsch, Rohwer, 2007). The piecewise exponential model generates a period-specific constant (a "y-intercept") for each designated time piece of the model. I used maximum likelihood estimation and the Huber-White-sandwich estimator of variance, which clusters observations on states, to produce robust standard errors. ${ }^{7}$

\section{Results}

Descriptive statistics and bivariate correlations are provided in table 8. Twenty-nine states had three or more competing trade associations and 19 states had Blau index scores of above .50, indicating moderate to high levels of institutional actor heterogeneity. The first biodiesel founding occurred in 1993 in Missouri, with one or two more a year in a few other states. Foundings began to increase beginning in 2002 and by 2007 , the states averaged 1.70 foundings per year with Texas leading the way with 8.5 foundings per year. The hazard model predicting biodiesel founding events and recombinatorial technology founding events is provided in tables 9 and 10 and the general least squares regression predicting technological diversity is provided in table 11. Turning to the measures of actor heterogeneity and interactions on biodiesel

\footnotetext{
${ }^{7}$ I also replicated this analysis in a fixed effects model and Cox hazard model and found similar results.
} 
foundings and recombinatorial technology in table 9, the first model contains the control variables; the second model adds the strength of a particular trade association promoting a specific technology as measured by membership; the third model adds the impact of opposition variety on foundings and recombinatorial technology founding events; and the fourth model adds the interaction of trade association strength (membership) with trade association heterogeneity.

Several of the control variables had a significant impact on new venture startup. Raw material availability, state mandate laws, and to a lesser extent federal subsidy and state diesel consumption all positively impacted biodiesel foundings, while industry age had a negative impact on foundings, consistent with prior expectations. Interestingly, biodiesel profitability (diesel price minus raw material prices) was negatively correlated with biodiesel foundings. Since 2004, the price for organic oils from soybeans, restaurant traps, and animals, etc., has risen higher than the price of petroleum, thereby squeezing production margins and making the industry almost entirely unprofitable if it were not for state and federal subsidies. Quite possibly, expectations that government will continue subsidizing production coupled with institutional actor support for founding a firm may be what are driving entrepreneurial interest in a largely unprofitable sector.

The results provide general support of hypotheses 1 and 5 . Coefficients in model four of table 9 indicate that a greater heterogeneity of institutional actors increased biodiesel foundings, thereby supporting hypothesis 1 . In model 3 of table 10, results show that institutional actor heterogeneity increased foundings of biodiesel ventures with recombinatorial technologies, thereby supporting hypothesis 5 . 


\section{Table 8}

Descriptive Statistics and Bivariate Correlations

\begin{tabular}{clcc}
\hline \multicolumn{1}{c}{ Variable } & Mean & Std. Dev. \\
\hline $\mathbf{1}$ & State technological diversity & 0.178 & 0.254 \\
$\mathbf{2}$ & State population density & 293 & 1108 \\
$\mathbf{3}$ & Gross state product & 178229 & 222472 \\
$\mathbf{4}$ & Available raw materials & 1200000000 & 1830000000 \\
$\mathbf{5}$ & Raw material heterogeneity & 0.524 & 0.222 \\
$\mathbf{6}$ & Farmland density & 0.249 & 0.172 \\
$\mathbf{7}$ & Chemical engineers & 18094 & 22770 \\
$\mathbf{8}$ & Industry age & 9 & 5.480 \\
& State diesel consumption (thousands of & & \\
$\mathbf{9}$ & barrels/year) & 25570 & 21410 \\
$\mathbf{1 0}$ & Biodiesel profitability (cents) & -113.022 & 42.052 \\
$\mathbf{1 1}$ & Biodiesel density & 0.118 & 0.503 \\
$\mathbf{1 2}$ & Surrounding state biodiesel density & 0.570 & 1.682 \\
$\mathbf{1 3}$ & State biodiesel production incentive laws & 0.076 & 0.266 \\
$\mathbf{1 4}$ & State biodiesel production mandate laws & 0.010 & 0.101 \\
& Surrounding state biodiesel production incentive & & \\
$\mathbf{1 5}$ & laws & 0.072 & 0.170 \\
& Surrounding state biodiesel production mandate & & \\
$\mathbf{1 6}$ & laws & 0.010 & 0.051 \\
$\mathbf{1 7}$ & Federal subsidy & 0.263 & 0.441 \\
$\mathbf{1 8}$ & Total trade associations' membership & 1035 & 2172 \\
$\mathbf{1 9}$ & Trade association variety & 0.321 & 0.216 \\
& Trade association variety * Trade associations' & & \\
$\mathbf{2 0}$ & membership & 576 & 1128
\end{tabular}


Table 8 (Continued)

\begin{tabular}{cccccccc}
\hline & $\mathbf{1}$ & $\mathbf{2}$ & $\mathbf{3}$ & $\mathbf{4}$ & $\mathbf{5}$ & $\mathbf{6}$ & $\mathbf{7}$ \\
\hline 1 & 1 & & & & & & \\
2 & -0.080 & 1 & & & & & \\
3 & 0.292 & 0.321 & 1 & & & & \\
4 & -0.100 & -0.154 & -0.031 & 1 & & & \\
5 & 0.205 & -0.044 & 0.257 & 0.017 & 1 & & \\
6 & -0.140 & -0.403 & -0.174 & 0.676 & 0.287 & 1 & \\
7 & 0.111 & 0.505 & 0.807 & 0.108 & 0.255 & -0.060 & 1 \\
8 & 0.444 & 0.119 & 0.057 & -0.273 & 0.119 & -0.384 & -0.037 \\
9 & 0.298 & 0.224 & 0.875 & 0.007 & 0.358 & -0.020 & 0.818 \\
10 & 0.008 & 0.064 & 0.062 & -0.219 & -0.120 & -0.290 & -0.056 \\
11 & 0.397 & -0.145 & 0.299 & -0.019 & 0.253 & 0.162 & 0.194 \\
12 & 0.334 & -0.256 & -0.246 & -0.023 & 0.153 & 0.093 & -0.251 \\
13 & 0.204 & -0.009 & -0.018 & 0.002 & 0.199 & 0.023 & -0.016 \\
14 & 0.090 & -0.041 & 0.034 & 0.082 & 0.080 & -0.048 & -0.071 \\
15 & 0.373 & -0.089 & -0.081 & 0.021 & 0.140 & 0.020 & -0.070 \\
16 & 0.322 & -0.024 & -0.023 & -0.037 & 0.084 & -0.065 & -0.021 \\
17 & 0.370 & 0.130 & 0.035 & -0.267 & 0.127 & -0.356 & -0.074 \\
18 & -0.094 & -0.135 & -0.092 & 0.919 & -0.041 & 0.535 & 0.010 \\
19 & 0.059 & -0.221 & -0.182 & 0.259 & 0.086 & 0.356 & -0.151 \\
20 & -0.116 & -0.143 & -0.119 & 0.911 & -0.053 & 0.543 & -0.019
\end{tabular}

\begin{tabular}{rccccccc}
\hline & 8 & 9 & 10 & 11 & 12 & 13 & 14 \\
\hline 8 & 1 & & & & & & \\
9 & 0.064 & 1 & & & & & \\
10 & 0.351 & 0.002 & 1 & & & & \\
11 & 0.142 & 0.381 & -0.051 & 1 & & & \\
12 & 0.435 & -0.164 & -0.008 & 0.200 & 1 & & \\
13 & 0.390 & -0.002 & 0.028 & 0.075 & 0.237 & 1 & \\
14 & 0.164 & 0.034 & -0.046 & 0.078 & 0.099 & 0.134 & 1 \\
15 & 0.587 & -0.032 & -0.060 & 0.198 & 0.467 & 0.409 & 0.128 \\
16 & 0.355 & -0.006 & -0.134 & 0.215 & 0.281 & 0.153 & 0.048 \\
17 & 0.851 & 0.028 & 0.425 & 0.130 & 0.367 & 0.334 & 0.116 \\
18 & -0.247 & -0.095 & -0.185 & -0.072 & -0.054 & -0.039 & 0.114 \\
19 & -0.058 & -0.016 & -0.085 & 0.151 & -0.030 & 0.057 & -0.054 \\
20 & -0.250 & -0.109 & -0.187 & -0.070 & -0.065 & -0.051 & 0.118
\end{tabular}


Table 8 (Continued)

\begin{tabular}{cccccc}
\hline & 15 & 16 & 17 & 18 & 19 \\
\hline 15 & 1 & & & & \\
16 & 0.398 & 1 & & & \\
17 & 0.492 & 0.243 & 1 & & \\
18 & -0.015 & -0.027 & -0.240 & 1 & \\
19 & 0.077 & -0.085 & -0.063 & 0.222 & 1 \\
20 & -0.018 & -0.033 & -0.242 & 0.995 & 0.253
\end{tabular}


Table 9

Piecewise Exponential Model of Biodiesel Founding Events by State-Year

\begin{tabular}{|c|c|c|c|c|}
\hline Variables & Model 1 & Model 2 & Model 3 & Model 4 \\
\hline 1990-1994† & $\begin{array}{c}-18.655 \\
(1.394)\end{array}$ & $\begin{array}{c}-17.149 \\
(1.428)\end{array}$ & $\begin{array}{c}-14.636 \\
1.742303\end{array}$ & $\begin{array}{c}-14.568 \\
(1.765)\end{array}$ \\
\hline 1995-1999 & $\begin{array}{l}-13.162 \\
(1.514)\end{array}$ & $\begin{array}{l}-11.690 \\
(1.612)\end{array}$ & $\begin{array}{c}-11.748 \\
(1.855)\end{array}$ & $\begin{array}{l}-11.669 \\
(1.906)\end{array}$ \\
\hline $2000-2004$ & $\begin{array}{c}-9.812 \\
(1.860)\end{array}$ & $\begin{array}{l}-8.344 \\
(1.887)\end{array}$ & $\begin{array}{l}-8.434 \\
(1.988)\end{array}$ & $\begin{array}{l}-8.355 \\
(2.029)\end{array}$ \\
\hline $2005-2008$ & $\begin{array}{l}-6.191 \\
(2.048)\end{array}$ & $\begin{array}{l}-4.741 \\
(2.067)\end{array}$ & $\begin{array}{l}-4.759 \\
(2.144)\end{array}$ & $\begin{array}{l}-4.678 \\
(2.190)\end{array}$ \\
\hline Population density & $\begin{array}{l}-0.000 \\
(0.000)\end{array}$ & $\begin{array}{l}-0.000^{*} \\
(0.000)\end{array}$ & $\begin{array}{l}-0.000 \\
(0.000)\end{array}$ & $\begin{array}{l}-0.000 \\
(0.000)\end{array}$ \\
\hline Gross state product (in millions) & $\begin{array}{l}-0.219 \\
(0.153)\end{array}$ & $\begin{array}{c}-0.291^{\star *} \\
(0.147)\end{array}$ & $\begin{array}{c}0.058 \\
(0.202)\end{array}$ & $\begin{array}{c}0.050 \\
(0.228)\end{array}$ \\
\hline Available raw materials (logged) & $\begin{array}{c}0.223^{\star \star \star *} \\
(0.059)\end{array}$ & $\begin{array}{l}0.137^{\star *} \\
(0.064)\end{array}$ & $\begin{array}{l}0.134^{*} \\
(0.073)\end{array}$ & $\begin{array}{l}0.131^{*} \\
(0.077)\end{array}$ \\
\hline Raw material heterogeneity & $\begin{array}{l}-0.448 \\
(0.520)\end{array}$ & $\begin{array}{l}-0.283 \\
(0.514)\end{array}$ & $\begin{array}{c}0.104 \\
(0.658)\end{array}$ & $\begin{array}{c}0.111 \\
(0.658)\end{array}$ \\
\hline Farmland density & $\begin{array}{c}0.333 \\
(0.377)\end{array}$ & $\begin{array}{c}0.197 \\
(0.381)\end{array}$ & $\begin{array}{c}0.265 \\
(0.383)\end{array}$ & $\begin{array}{c}0.268 \\
(0.386)\end{array}$ \\
\hline Chemical engineers / 100,000 & $\begin{array}{l}-0.116 \\
(0.538)\end{array}$ & $\begin{array}{c}-0.378 \\
(0.494)\end{array}$ & $\begin{array}{l}-0.743 \\
(0.491)\end{array}$ & $\begin{array}{l}-0.725 \\
(0.475)\end{array}$ \\
\hline Industry age & $\begin{array}{c}-0.335^{\star \star \star} \\
(0.114)\end{array}$ & $\begin{array}{c}-0.329^{\star \star \star} \\
(0.115)\end{array}$ & $\begin{array}{c}-0.376^{\star \star \star} \\
(0.110)\end{array}$ & $\begin{array}{c}-0.375^{\star \star \star} \\
(0.110)\end{array}$ \\
\hline $\begin{array}{l}\text { State diesel consumption (millions of } \\
\text { barrels/year) }\end{array}$ & $\begin{array}{c}0.007 \\
(0.004)\end{array}$ & $\begin{array}{l}0.010^{* *} \\
(0.005)\end{array}$ & $\begin{array}{l}0.008^{*} \\
(0.005)\end{array}$ & $\begin{array}{l}0.009^{*} \\
(0.005)\end{array}$ \\
\hline Biodiesel profitability (cents) & $\begin{array}{l}-0.010^{* * *} \\
(0.002)\end{array}$ & $\begin{array}{c}-0.011^{* \star *} \\
(0.002)\end{array}$ & $\begin{array}{c}-0.010^{* * *} \\
(0.002)\end{array}$ & $\begin{array}{c}-0.010^{* * *} \\
(0.002)\end{array}$ \\
\hline Biodiesel density & $\begin{array}{l}0.117^{\star} \\
(0.065)\end{array}$ & $\begin{array}{l}0.113^{*} \\
(0.069)\end{array}$ & $\begin{array}{c}0.092 \\
(0.063)\end{array}$ & $\begin{array}{c}0.092 \\
(0.064)\end{array}$ \\
\hline Surrounding state biodiesel density & $\begin{array}{c}0.007 \\
(0.029)\end{array}$ & $\begin{array}{c}0.011 \\
(0.029)\end{array}$ & $\begin{array}{c}0.030 \\
(0.028)\end{array}$ & $\begin{array}{l}0.029 \\
(0.030)\end{array}$ \\
\hline $\begin{array}{l}\text { State biodiesel production incentive } \\
\text { laws }\end{array}$ & $\begin{array}{l}-0.188 \\
(0.123)\end{array}$ & $\begin{array}{l}-0.192 \\
(0.130)\end{array}$ & $\begin{array}{l}-0.211 \\
(0.132)\end{array}$ & $\begin{array}{l}-0.215^{\star} \\
(0.130)\end{array}$ \\
\hline $\begin{array}{l}\text { State biodiesel production mandate } \\
\text { laws }\end{array}$ & $\begin{array}{l}0.713^{\star \star *} \\
(0.188)\end{array}$ & $\begin{array}{l}0.602^{\star \star \star} \\
(0.206)\end{array}$ & $\begin{array}{l}0.707^{\star \star *} \\
(0.173)\end{array}$ & $\begin{array}{l}0.711^{\star * *} \\
(0.172)\end{array}$ \\
\hline $\begin{array}{l}\text { Surrounding state biodiesel production } \\
\text { incentive laws }\end{array}$ & $\begin{array}{l}-0.079 \\
(0.278)\end{array}$ & $\begin{array}{l}-0.030 \\
(0.279)\end{array}$ & $\begin{array}{l}-0.022 \\
(0.260)\end{array}$ & $\begin{array}{l}-0.025 \\
(0.271)\end{array}$ \\
\hline $\begin{array}{l}\text { Surrounding state biodiesel production } \\
\text { mandate laws }\end{array}$ & $\begin{array}{l}0.100 \\
(0.455)\end{array}$ & $\begin{array}{l}-0.022 \\
(0.484)\end{array}$ & $\begin{array}{c}0.279 \\
(0.500)\end{array}$ & $\begin{array}{l}0.263 \\
(0.551)\end{array}$ \\
\hline
\end{tabular}


Table 9 (Continued)

\begin{tabular}{|c|c|c|c|c|}
\hline Federal subsidy & $\begin{array}{l}1.060^{*} \\
(0.554)\end{array}$ & $\begin{array}{l}0.997^{\star} \\
(0.551)\end{array}$ & $\begin{array}{l}1.077^{\star} \\
(0.591)\end{array}$ & $\begin{array}{l}1.076^{\star} \\
(0.592)\end{array}$ \\
\hline Total trade associations' size / 1000 & & $\begin{array}{c}0.061^{* * *} \\
(0.023)\end{array}$ & $\begin{array}{l}0.053^{\star *} \\
(0.024)\end{array}$ & $\begin{array}{c}0.045 \\
(0.148)\end{array}$ \\
\hline Trade association heterogeneity & & & $\begin{array}{l}1.024^{\star * *} \\
(0.353)\end{array}$ & $\begin{array}{l}0.965^{\star \star \star} \\
(0.370)\end{array}$ \\
\hline $\begin{array}{l}\text { Trade association heterogeneity } X \\
\text { Trade associations' size }\end{array}$ & & & & $\begin{array}{l}0.113^{\star *} \\
(0.052)\end{array}$ \\
\hline Wald chi squared & $52699.72^{\star \star \star}$ & $47417.43^{\star \star \star}$ & $75636.24^{\star \star \star}$ & $84864.84^{\star \star \star}$ \\
\hline
\end{tabular}


Table 10

Piecewise Exponential Model of Recombinatorial-Technology Biodiesel Founding Events by State-Year

\begin{tabular}{|c|c|c|c|c|}
\hline Variables & Model 1 & Model 2 & Model 3 & Model 4 \\
\hline 1990-1994† & $\begin{array}{c}-32.735 \\
(1.895)\end{array}$ & $\begin{array}{l}-29.681 \\
(2.183)\end{array}$ & $\begin{array}{l}-28.417 \\
(2.877)\end{array}$ & $\begin{array}{c}-28.415 \\
(2.966)\end{array}$ \\
\hline 1995-1999 & $\begin{array}{l}-14.295 \\
(2.440)\end{array}$ & $\begin{array}{l}-12.401 \\
(2.670)\end{array}$ & $\begin{array}{l}-13.250 \\
(3.194)\end{array}$ & $\begin{array}{l}-13.253 \\
(3.322)\end{array}$ \\
\hline $2000-2004$ & $\begin{array}{l}-10.287 \\
(3.269)\end{array}$ & $\begin{array}{l}-8.3223 \\
(3.543)\end{array}$ & $\begin{array}{c}-9.432 \\
(4.063)\end{array}$ & $\begin{array}{l}-9.435 \\
(4.158)\end{array}$ \\
\hline 2005-2008 & $\begin{array}{l}-6.929 \\
(3.658)\end{array}$ & $\begin{array}{l}-4.948 \\
(3.927)\end{array}$ & $\begin{array}{l}-6.007 \\
(4.531)\end{array}$ & $\begin{array}{l}-6.012 \\
(4.648)\end{array}$ \\
\hline Population density & $\begin{array}{l}-0.000 \\
(0.000)\end{array}$ & $\begin{array}{l}-0.000 \\
(0.000)\end{array}$ & $\begin{array}{c}0.000 \\
(0.000)\end{array}$ & $\begin{array}{c}0.000 \\
(0.000)\end{array}$ \\
\hline Gross state product (in millions) & $\begin{array}{c}0.007 \\
(0.350)\end{array}$ & $\begin{array}{l}-0.063 \\
(0.356)\end{array}$ & $\begin{array}{c}0.217 \\
(0.404)\end{array}$ & $\begin{array}{c}0.219 \\
(0.413)\end{array}$ \\
\hline Available raw materials (logged) & $\begin{array}{l}0.280^{\star *} \\
(0.118)\end{array}$ & $\begin{array}{c}0.172 \\
(0.137)\end{array}$ & $\begin{array}{c}0.181 \\
(0.163)\end{array}$ & $\begin{array}{c}0.182 \\
(0.172)\end{array}$ \\
\hline Raw material heterogeneity & $\begin{array}{l}-0.452 \\
(0.933)\end{array}$ & $\begin{array}{l}-0.194 \\
(0.897)\end{array}$ & $\begin{array}{c}0.322 \\
(1.026)\end{array}$ & $\begin{array}{c}0.318 \\
(1.029)\end{array}$ \\
\hline Farmland density & $\begin{array}{l}-0.492 \\
(0.570)\end{array}$ & $\begin{array}{l}-0.660 \\
(0.592)\end{array}$ & $\begin{array}{l}-0.523 \\
(0.692)\end{array}$ & $\begin{array}{l}-0.523 \\
(0.691)\end{array}$ \\
\hline Chemical engineers / 100,000 & $\begin{array}{c}-2.431^{\star \star *} \\
(0.915)\end{array}$ & $\begin{array}{c}-2.805^{\star \star \star} \\
(0.863)\end{array}$ & $\begin{array}{c}-3.410^{* * *} \\
(0.974)\end{array}$ & $\begin{array}{c}-3.423^{\star \star *} \\
(1.019)\end{array}$ \\
\hline Industry age & $\begin{array}{c}-0.519 * \star \\
(0.238)\end{array}$ & $\begin{array}{c}-0.523^{\star \star} \\
(0.234)\end{array}$ & $\begin{array}{l}-0.503^{*} \\
(0.259)\end{array}$ & $\begin{array}{l}-0.503^{\star} \\
(0.259)\end{array}$ \\
\hline $\begin{array}{l}\text { State diesel consumption (millions of } \\
\text { barrels/year) }\end{array}$ & $\begin{array}{c}0.011 \\
(0.008)\end{array}$ & $\begin{array}{l}0.014^{*} \\
(0.008)\end{array}$ & $\begin{array}{l}0.014^{*} \\
(0.008)\end{array}$ & $\begin{array}{l}0.014^{*} \\
(0.008)\end{array}$ \\
\hline Biodiesel profitability (cents) & $\begin{array}{c}-0.012^{\star \star \star} \\
(0.005)\end{array}$ & $\begin{array}{l}-0.013^{\star \star \star} \\
(0.005)\end{array}$ & $\begin{array}{l}-0.012^{\star *} \\
(0.005)\end{array}$ & $\begin{array}{l}-0.012^{\star \star} \\
(0.005)\end{array}$ \\
\hline Biodiesel density & $\begin{array}{l}0.256^{\star \star} \\
(0.110)\end{array}$ & $\begin{array}{l}0.259^{\star *} \\
(0.110)\end{array}$ & $\begin{array}{l}0.230^{\star *} \\
(0.105)\end{array}$ & $\begin{array}{l}0.230^{\star *} \\
(0.105)\end{array}$ \\
\hline Surrounding state biodiesel density & $\begin{array}{l}0.070^{\star *} \\
(0.032)\end{array}$ & $\begin{array}{l}0.076^{\star *} \\
(0.031)\end{array}$ & $\begin{array}{l}0.093^{\star * \star} \\
(0.035)\end{array}$ & $\begin{array}{l}0.094^{\star *} \\
(0.039)\end{array}$ \\
\hline State biodiesel production incentive & & & & 0228 \\
\hline ( & $\begin{array}{l}0.26 / \\
(0.204)\end{array}$ & $\begin{array}{c}0.253 \\
(0.209)\end{array}$ & $\begin{array}{c}0.226 \\
(0.210)\end{array}$ & $\begin{array}{c}0.228 \\
(0.209)\end{array}$ \\
\hline $\begin{array}{l}\text { State biodiesel production mandate } \\
\text { laws }\end{array}$ & $\begin{array}{c}0.529 \\
(0.374)\end{array}$ & $\begin{array}{c}0.410 \\
(0.414)\end{array}$ & $\begin{array}{c}0.496 \\
(0.375)\end{array}$ & $\begin{array}{c}0.494 \\
(0.380)\end{array}$ \\
\hline
\end{tabular}


Table 10 (Continued)

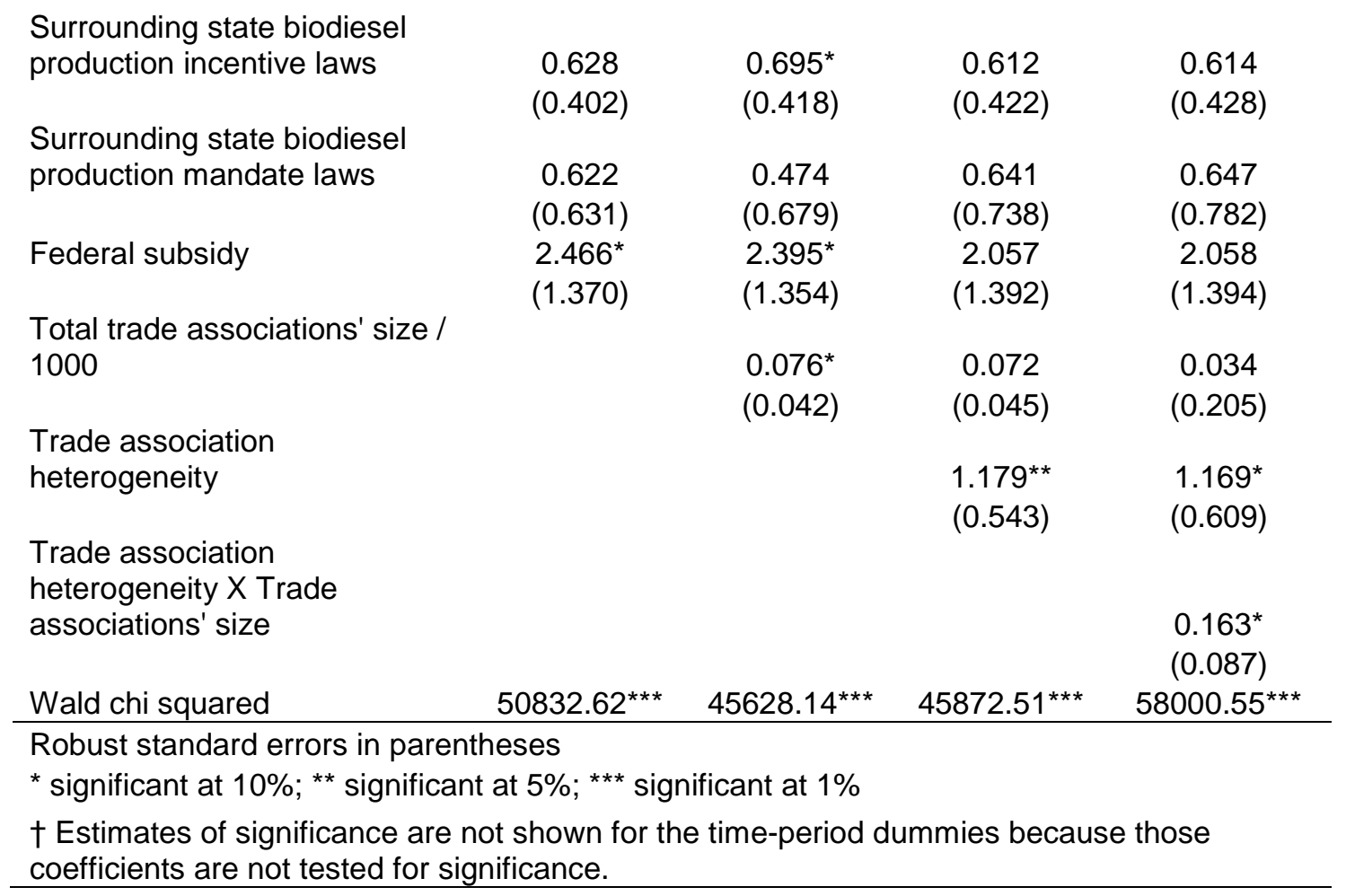


Table 11

General Least Squares Analysis of Technological Diversity of Biodiesel Foundings by State-Year

\begin{tabular}{|c|c|c|c|c|}
\hline Variables & Model 1 & Model 2 & Model 3 & Model 4 \\
\hline Population density & $\begin{array}{l}0.000 \\
(0.000)\end{array}$ & $\begin{array}{c}0.000 \\
(0.000)\end{array}$ & $\begin{array}{l}0.000 \\
(0.000)\end{array}$ & $\begin{array}{c}0.000 \\
(0.000)\end{array}$ \\
\hline Gross state product (in millions) & $\begin{array}{c}0.270^{\star * *} \\
(0.072)\end{array}$ & $\begin{array}{c}0.241^{* * *} \\
(0.072)\end{array}$ & $\begin{array}{l}0.323^{\star \star *} \\
(0.078)\end{array}$ & $\begin{array}{l}0.262^{* * *} \\
(0.082)\end{array}$ \\
\hline Available raw materials (logged) & $\begin{array}{c}0.002 \\
(0.007)\end{array}$ & $\begin{array}{l}-0.004 \\
(0.007)\end{array}$ & $\begin{array}{l}-0.015^{\star *} \\
(0.007)\end{array}$ & $\begin{array}{l}-0.017^{\star \star} \\
(0.007)\end{array}$ \\
\hline Raw material heterogeneity & $\begin{array}{l}-0.066 \\
(0.062)\end{array}$ & $\begin{array}{l}-0.013 \\
(0.067)\end{array}$ & $\begin{array}{l}0.114 \\
(0.075)\end{array}$ & $\begin{array}{c}0.122 \\
(0.076)\end{array}$ \\
\hline Farmland density & $\begin{array}{l}-0.073 \\
(0.088)\end{array}$ & $\begin{array}{l}-0.199 * \\
(0.113)\end{array}$ & $\begin{array}{l}-0.231^{*} \\
(0.122)\end{array}$ & $\begin{array}{l}-0.207^{*} \\
(0.118)\end{array}$ \\
\hline Chemical engineers / 100,000 & $\begin{array}{c}-0.439 * * * \\
(0.102)\end{array}$ & $\begin{array}{c}-0.434^{\star * *} \\
(0.103)\end{array}$ & $\begin{array}{c}-0.384^{\star \star \star} \\
(0.107)\end{array}$ & $\begin{array}{r}0.489^{\star \star \star} \\
(0.119)\end{array}$ \\
\hline Industry age & $\begin{array}{c}0.001 \\
(0.005)\end{array}$ & $\begin{array}{l}-0.001 \\
(0.005)\end{array}$ & $\begin{array}{l}-0.005 \\
(0.006)\end{array}$ & $\begin{array}{l}-0.004 \\
(0.006)\end{array}$ \\
\hline $\begin{array}{l}\text { State diesel consumption (millions of } \\
\text { barrels/year) }\end{array}$ & $\begin{array}{r}2.847^{\star \star \star} \\
(0.956)\end{array}$ & $\begin{array}{l}3.216^{\star \star *} \\
(0.974)\end{array}$ & $\begin{array}{l}2.291^{\star *} \\
(1.043)\end{array}$ & $\begin{array}{l}3.299^{* \star \star} \\
(1.122)\end{array}$ \\
\hline Biodiesel profitability (cents) & $\begin{array}{l}-0.001^{\star *} \\
(0.000)\end{array}$ & $\begin{array}{l}-0.001^{\star *} \\
(0.000)\end{array}$ & $\begin{array}{l}-0.000 \\
(0.000)\end{array}$ & $\begin{array}{l}-0.000 \\
(0.000)\end{array}$ \\
\hline Biodiesel density & $\begin{array}{c}0.059 * \star * \\
(0.015)\end{array}$ & $\begin{array}{l}0.067^{* * *} \\
(0.015)\end{array}$ & $\begin{array}{c}0.055^{\star \star *} \\
(0.015)\end{array}$ & $\begin{array}{l}0.056^{* \star *} \\
(0.015)\end{array}$ \\
\hline Surrounding state biodiesel density & $\begin{array}{l}0.016^{* * *} \\
(0.005)\end{array}$ & $\begin{array}{l}0.016^{* * *} \\
(0.005)\end{array}$ & $\begin{array}{c}0.025^{\star \star \star} \\
(0.005)\end{array}$ & $\begin{array}{l}0.019^{* \star \star} \\
(0.005)\end{array}$ \\
\hline State biodiesel production incentive laws & $\begin{array}{c}0.032 \\
(0.029)\end{array}$ & $\begin{array}{c}0.030 \\
(0.030)\end{array}$ & $\begin{array}{l}-0.013 \\
(0.030)\end{array}$ & $\begin{array}{l}-0.018 \\
(0.029)\end{array}$ \\
\hline State biodiesel production mandate laws & $\begin{array}{l}-0.105^{\star *} \\
(0.046)\end{array}$ & $\begin{array}{c}-0.135^{\star \star *} \\
(0.052)\end{array}$ & $\begin{array}{l}-0.099^{*} \\
(0.052)\end{array}$ & $\begin{array}{l}-0.090^{*} \\
(0.049)\end{array}$ \\
\hline $\begin{array}{l}\text { Surrounding state biodiesel production } \\
\text { incentive laws }\end{array}$ & $\begin{array}{c}0.177^{\star \star \star} \\
(0.058)\end{array}$ & $\begin{array}{l}0.174^{\star \star \star} \\
(0.059)\end{array}$ & $\begin{array}{l}0.102^{*} \\
(0.060)\end{array}$ & $\begin{array}{c}0.083 \\
(0.060)\end{array}$ \\
\hline $\begin{array}{l}\text { Surrounding state biodiesel production } \\
\text { mandate laws }\end{array}$ & $\begin{array}{l}0.283^{\star *} \\
(0.131)\end{array}$ & $\begin{array}{l}0.234^{*} \\
(0.130)\end{array}$ & $\begin{array}{l}0.282^{* *} \\
(0.119)\end{array}$ & $\begin{array}{l}0.265^{\star *} \\
(0.114)\end{array}$ \\
\hline Federal subsidy & $\begin{array}{l}0.055 \\
(0.037)\end{array}$ & $\begin{array}{l}0.059 \\
(0.038)\end{array}$ & $\begin{array}{l}0.070^{*} \\
(0.042)\end{array}$ & $\begin{array}{l}0.081^{*} \\
(0.043)\end{array}$ \\
\hline $\begin{array}{l}\text { Total trade associations' membership / } \\
100,000\end{array}$ & & $\begin{array}{l}0.739 * \\
(0.400)\end{array}$ & $\begin{array}{c}0.677 \\
(0.420)\end{array}$ & $\begin{array}{l}0.126^{\star \star \star} \\
(0.038)\end{array}$ \\
\hline
\end{tabular}


Table 11 (Continued)

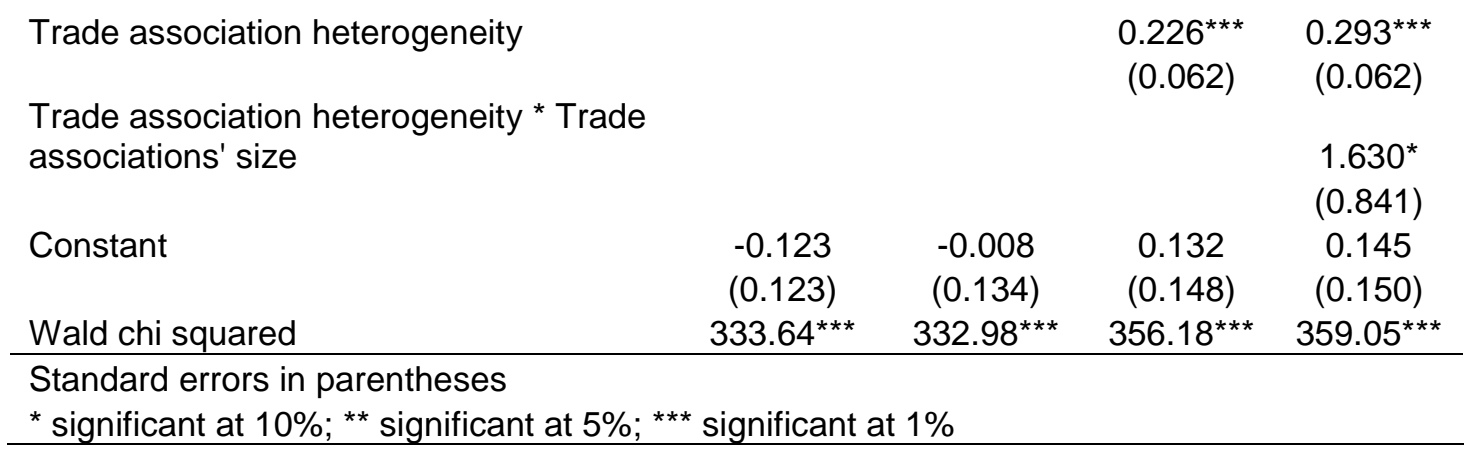


Moreover, model 4 in table 9 and model 8 in table 10 demonstrate that institutional actor strength, or the sum of total number of association members promoting competing technologies, positively moderates the effect of trade association heterogeneity on foundings and generation of recombinatory technologies, thereby supporting hypotheses 3 and 6.

Moving to the measures of actor heterogeneity and interactions on technological variation in table 11, the first model contains the control variables; the second model adds trade association strength as measured by total membership of those promoting biodiesel; the third model adds the impact of opposition actors on technological variation; and the fourth model adds the interaction of trade association strength (membership) with trade association heterogeneity. Several of the control variables significantly affected technological variation. Gross state product, state diesel consumption, biodiesel density, surrounding state biodiesel density and surrounding state biodiesel production mandate laws all had positive effects on technological variation while the number chemical engineers, and state biodiesel production mandate laws seemed to decrease technological variation. Organizational ecologists assert that greater competition lends to resource partitioning wherein niche players emerge to capture resources not absorbed by generalists (Freeman and Hannan, 1983). This may explain why greater competition (density in focal and surrounding states) leads to greater numbers of biodiesel producers utilizing different feedstock technologies. The negative effect of production mandate laws on technological variation suggests that state laws may have an effect of favoring one technology over others.

The results support hypotheses 2 and 4 . In model three, the results illustrate that greater heterogeneity among institutional actors promoting various prescriptions and information had a positive impact on technological diversity, thereby supporting 
hypothesis 2. Likewise, the results in model four show that greater institutional actor strength positively amplified the effects of institutional heterogeneity, thus lending support to hypothesis 4 .

\section{Discussion}

In this paper, I examined how competing institutional actors can affect entrepreneurial activity and technological choice at the beginning of a new sector and technological lifecycle. The analyses showed that greater actor heterogeneity had a positive effect on entrepreneurial activity as well as technological variation and innovation and that its effect was amplified by the strength of the actors promoting prescriptions and information. By appealing to a broad set of values and resources, institutional actor variation spurred foundings of biodiesel ventures using multiple technological processes. A greater heterogeneity of institutional actors also increased the development of recombinatorial technologies among new ventures by providing entrepreneurs with a wide repertoire of technological values and information.

This paper makes several theoretical contributions. First, this paper contributes to the nexus of institutional and entrepreneurship research by considering how actor heterogeneity can affect the emergence of new organizations and spur technological diversity and innovation. A number of studies have explored how actor strength can promote the adoption of a new practice or the founding of a new organizational form (Lounsbury, 2001; Schneiberg, King, and Smith, 2008; Sine and Lee, 2009), but none of them have investigated how actor variation can affect entrepreneurial activity. Interestingly, the results indicate that institutional actor heterogeneity or competition had a greater effect than the strength or net size of actors on founding rates, recombinatorial innovation, and technological diversity. Given the power that heterogeneity has in shaping new sector development and entrepreneurial activity, 
scholars may want to pay greater attention to heterogeneity in future institutional and organizational studies.

Second, this paper builds upon the technology entrepreneurship research which is concerned about how new technologies develop and evolve over time (Tushman and Anderson, 1986). While researchers acknowledge the influence of institutional pressures on innovation and variation, most of this work focuses on the effect of standards and dominant designs at the industry level (Anderson and Tushman, 1990; Garud and Kumaraswamy, 1995), and neglects other kinds of institutional pressures that may enable or constrain technological development at the firm level. Thus, prior studies largely focus on technological adoption and development after the inflection point of the technological s-curve, largely overlooking other factors that affect entrepreneurial decision-making in the early periods. Building on past research this paper finds that greater institutional actor competition can profoundly influence technological development and variation at the beginning of new sectors and technological lifecycles by stimulating new-venture technological innovation and variation.

Third, this paper also contributes to the research on institutional actor collaborations and alliances (Lawrence, Hardy, and Phillips, 2002; Maguire, Hardy, and Lawrence, 2004). While the institutional actors in this study competed with each other regarding the kind of biodiesel technology they promoted, they also collaborated at times to move the sector forward by endorsing and becoming members of the biodiesel sector's trade association, the National Biodiesel Board. The results suggest that for institutional-actor collaboration to have the greatest effect on new organizational development, influence among members must be nearly equal (maximum heterogeneity). While the strength or size of the collaboration does make a difference on impact, collaborations or alliances must make sure to strike the right 
balance between heterogeneity and size in order to maximize the differences of information and characteristics among the organizational members.

Finally, this paper empirically contributes to our understanding of trade associations. Trade associations are entities that arise after a new sector has been formed with the purpose of defending and promoting the interests of their business firms (Aldrich and Staber, 1988). In the fight to represent their members' political and economic preferences, organizational researchers have traditionally cast trade associations as opponents of innovation and institutional change that rely upon member and lobbying influence to squash emergence of new organizations (Aldrich, Zimmer, Staber, and Beggs, 1994; Sine, Haveman, and Tolbert, 2005). In contrast to previous studies, this paper finds that trade associations can actually be antecedents to and catalysts of new sectors and technologies by promoting prescriptions and scripts outside of their domain that change individuals’ perceptions of organizations and technologies. Thus, instead of just representing and defending existing business sectors, trade associations can actually create new ones.

This paper is not without its limitations. For example, I do not investigate how actor competition or heterogeneity may affect subsequent new-venture survival and performance. It is possible that greater actor variation may be positively correlated with startup survival and performance because various actors can provide entrepreneurs with a wide variety of choices to choose from which they can optimize or combine, thereby picking or developing the right technology for them and their environment. On the other hand, actor diversity may have a negative impact on newventure survival later because greater fragmentation among trade associations may dilute individual actor power and increase influence costs, making it more difficult for an individual actor to lobby for regulation that can benefit the promoted technology or 
practice (Rao, Morrill, and Zald, 2000). Research on the temporal effects of variation on new-venture survival is warranted.

Additionally, it is possible that too many actors promoting varying prescriptions and information may dampen entrepreneurial activity by undermining sector legitimacy and confusing entrepreneurs. For example, Meyer and Scott (1983) asserted that the legitimacy of an organizational form, arrangement or promoted concept is "negatively affected by the number of different authorities... and by the diversity or inconsistency of their accounts” (202). Likewise, research in social psychology suggests that having too many choices may have a negative effect because as options increase, the effort and time needed to process the available information may cause entrepreneurs to simply defer decisions, search for new alternatives, or simply decline to decide (Iyengar and Lepper, 2000; Iyengar, Huberman, and Jiang, 2004). Research that evaluates the possible negative consequences of too much actor heterogeneity on entrepreneurial activity and technological development is needed. 


\section{REFERENCES}

Abernathy, W. J. \& Utterback, J. M. 1978. Patterns of industrial innovation. Technology Review, 80: 40-47.

Albert, S. \& Whetten, D. A. 1985. Organizational identity. In L. L. Cummings \& B. M. Staw (Eds.), Research in Organizational Behavior, Vol. 7: 263-395. Greenwich, CT: JAI Press.

Aldrich, H. E. \& Fiol, C. M. 1994. Fools rush in? The institutional context of industry creation. Academy of Management Review, 19(4): 645-670.

Aldrich, H. E. \& Staber, U. H. 1988. Organizing business interests: Patterns of trade association foundings, transformations, and deaths. In G. R. Carroll (Ed.), Ecological Models of Organizations: 111-126. Cambridge, MA: Ballinger.

Aldrich, H. E., Zimmer, C. R., Staber, U. H., \& Beggs, J. J. 1994. Minimalism, Mutualism, and Maturity: The Evolution of the American Trade Association Population in the 20th Century. In J. A. C. Baum \& J. Singh (Eds.), Evolutionary Dynamics of Organizations. New York: Oxford University Press.

Amabile, T. M. 1996. Creativity in Context. Boulder, CO: Westview Press, 1996.

Anderson, P. \& Tushman, M. L. 1990. Technological Discontinuities and Dominant Designs: A Cyclical Model of Technological Change. Administrative Science Quarterly, 35(4): 604-633. 
Baker, T. \& Nelson, R. E. 2005. Creating something from nothing; Resource construction through entrepreneurial bricolage. Administrative Science Quarterly, 50: 329-366.

Baldridge, J. V. \& Burnham, R. A. 1975. Organizational innovation: Individual, organizational and environmental impacts. Administrative Science Quarterly, 20: 165176.

Barnett, W. P. \& Carroll, G. R. 1993. How institutional constraints affected the organization of early U.S. telephony. Journal of Law, Economics, \& Organization, 9(1): 98-126.

Blau, D. M. 1987. A time-series analysis of self-employment in the United States. The Journal of Political Economy, 95(3): 445-467.

Blau, P. M. 1977. Inequality and Heterogeneity. New York: The Free Press.

Blossfeld, H., Golsch, K., \& Rohwer, G. 2007. Event History Analysis with Stata. Mahwah, NJ: Lawrence Erlbaum Associates.

Blossfeld, H. \& Rohwer, G. 1995. Techniques of Event History Modeling: New Approaches to Causal Analysis. Mahwah, NJ: Erlbaum.

Brehier, L. 1907. Crusades. In C. G. Herbermann, E. A. Pace, C. B. Pallen, T. J. Shahan \& J. J. Wynne (Eds.), The Catholic Encyclopedia: 229-262. New York: Appleton.

Brown, L. \& Gutstein, E. 2009. The charter difference: A comparison of Chicago charter and neighborhood high schools. Chicago: University of Illinois-Chicago. 
Burton, M. D., Sorensen, J. B., \& Beckman, C. 2002. Coming from good stock:

Career histories and new venture formation. Social Structure and Organizations, 19: 229-262.

Campbell, D. T. 1960. Blind variation and selective retention in creative thought as in other knowledge processes. Psychological Review, 67: 380-400.

Carroll, G. R. \& Hannan, M. T. 2000. The Demography of Corporations and Industries. Princeton, NJ: Princeton University Press.

Cohen, J. \& Cohen, P. 1983. Applied Multiple Regression/Correlational Analysis for the Behavior Sciences. Hillsdale, NJ: Lawrence Erlbaum.

Coser, L. A. 1957. Social conflict and the theory of social change. The British Journal of Sociology, 8(3): 197-207.

Dewey, J. 1930. Human Nature and Conduct. New York: The Modern Library.

Diesel, R. 1913. The Diesel Oil-Engine and Its Industrial Importance Particularly for Great Britain. Chemical Abstracts, 7: 1605.

DiMaggio, P. J. \& Powell, W. W. 1983. The Iron Cage Revisited: Institutional Isomorphism and Collective Rationality in Organizational Fields. American Sociological Review, 48(2): 147-160.

DiMaggio, P. J. 1988. Interest and agency in institutional theory. In L. G. Zucker (Ed.), Institutional Patterns and Organizations: Culture and Environment: 3-21. Cambridge, MA: Ballinger. 
Dobrev, S. D. \& Barnett, W. P. 2005. Organizational Roles and Transition to Entrepreneurship. Academy of Management Journal, 48(3): 433-449.

Dowell, G. \& Swaminathan, A. 2006. Entry timing, exploration, and firm survival in the early years of the U.S. bicycle industry. Strategic Management Journal, 27: 11591182.

Dunne, T., Roberts, M. J., \& Larry, S. 1988. Patterns of firm entry and exit in U.S. manufacturing industries. Rand Journal of Economics, 19: 495-515.

Earl, B. \& Fisher, L. 2007. Phone interview with Brett Earl and Logan Fisher. Ithaca, NY.

Eckermann, Erik. 2001. World History of the Automobile. Warrendale, PA: Society of Automotive Engineers.

Evans, C. R. \& Jovanovic, B. 1989. An Estimated Model of Entrepreneurial Choice under Liquidity Constraints. The Journal of Political Economy, 97(4): 808-828.

Evans, D. L. L. 1989. Some empirical aspects of entrepreneurship. American Economics Review, 79: 519-535.

Freeman, J. \& Hannan, M. T. 1983. Niche width and the dynamics of organizational populations. The American Journal of Sociology, 88: 1116-1145.

Galison, P. 1997. Image and Logic: A Material Culture of Microphysics. Chicago: University of Chicago Press.

Garud, R., \& Kumaraswamy, A. 1995.Technological and organizational designs for realizing economies of substitution. Strategic Management Journal, 16: 93-109. 
Gilfillan, S. C. 1935. Inventing the Ship. Chicago, IL: Follett Publishing.

Greenwood, R. \& Suddaby, R. 2006. Institutional entrepreneurship in mature fields: The big five accounting firms. Academy of Management Journal, 49: 27-48.

Hannan, M. T. \& Freeman, J. 1977. The population ecology of organizations. American Journal of Sociology, 82: 929-964.

Hargrave, T. J. \& Van de Ven, A. H. 2006. A collective action model of institutional innovation. Academy of Management Review, 31(4): 864-888.

Haveman, H. A., Rao, H., \& Paruchuri, S. 2007. The Winds of Change: The Progressive Movement and the Bureaucratization of Thrift. American Sociological Review, 72(1): 117-142.

Hayek, F. A. 1949. The meaning of competition, Individualism and Economic Order: 92-106. London: Routledge \& Kegan Paul.

Hiatt, S. R., Sine, W. D., \& Tolbert, P. T. 2009. From Pabst to Pepsi: The deinstitutionalization of social practices and the creation of entrepreneurial opportunities. Administrative Science Quarterly, 54: 635-667.

Iyengar, S. S., Huberman, G., \& Jiang, W. 2004. How much choice is too much? Contributions to 401(k) retirement plans. In O. S. Mitchell \& S. Utkus (Eds.), $\underline{\text { Pension }}$ Design and Structure: New Lessons from Behavioral Finance: 83-95. Oxford, England: Oxford University Press.

Iyengar, S. S. \& Lepper, M. R. 2000. When choice is demotivating: Can one desire too much of a good thing? Journal of Personality and Social Psychology, 79(6): 995-1006. 
Kasof, J. 1997. Creativity and breadth of attention. Creativity Research Journal, 10: 303-315.

Katila, R. \& Shane, S. 2005. When does lack of resources make new firms innovative? Academy of Management Journal, 48(5): 814-829.

Kirzner, I. M. 1973. Competition and entrepreneurship. Chicago, IL: University of Chicago Press.

Kostova, T. \& Zaheer, S. 1999. Organizational legitimacy under conditions of complexity: The case of multinational enterprise. Academy of Management Review, 24(1): 64-81.

Kraatz, M. S. \& Block, E. S. 2008. Organizational implications of institutional pluralism. In R. Greenwood, C. Oliver, K. Sahlin-Andersson \& R. Suddaby (Eds.), The Handbook of Organizational Institutionalism: 243-275. London: Sage.

Lawrence, T. B., Hardy, C., \& Phillips, N. 2002. Institutional effects of interorganizational collaboration: The emergence of proto-institutions. Academy of Management Journal, 45(1): 281-290.

Lee, B. H. 2009. The infrastructure of collective action and policy content diffusion in the organic food industry. Academy of Management Journal, 52: 1247-1269.

Lounsbury, M. 2001. Institutional Sources of Practice Variation: Staffing College and University Recycling Programs. Administrative Science Quarterly, 46(1): 29-56.

Maguire, S., Hardy, C., \& Lawrence, T. B. 2004. Institutional entrepreneurship in emerging fields: HIV/AIDS treatment advocacy in Canada. Academy of Management Journal, 47(5): 657-679. 
Marquis, C. \& Lounsbury, M. 2007. Vive la resistance: Competing logics and the consolidation of U.S. community banking. Academy of Management Journal, 50: 799820.

Martindale, C. 1981. Cognition and Consciousness. Homewood, IL: Dorsey.

Meeker, D. L. 2006. Essential Rendering. Arlington, VA: Kirby Lithographic Company.

Mendelsohn, G., A. 1976. Associative and attentional processes in creative performance. Journal of Personality, 44(2): 341-369.

Mendelsohn, G. A. \& Griswold, B. B. 1964. Differential use of incidental stimuli in problem solving as a function of creativity. Journal of Abnormal and Social Psychology, 68: 431-436.

Meyer, J. W. \& Rowan, B. 1977. Institutionalized organizations: Formal structure as myth and ceremony. American Journal of Sociology, 83(2): 340-363.

Meyer, J. W. \& Scott, W. R. 1983. Centralization and the legitimacy problems of local government. In J. W. Meyer \& W. R. Scott (Eds.), Organizational Environments:

Ritual and Rationality: 199-215. Beverly Hills, CA: Sage.

Nelson, R. R. \& Winter, S. G. 1982. An Evolutionary Theory of Economic Change. Cambridge, MA: Belkap Press of Harvard University Press.

Oakley, J. 2007. Phone interview with John Oakley. Ithaca, NY.

Pfeffer, J. \& Salancik, G. 1978. The External Control of Organizations. New York: Harper \& Row. 
Phillips, D. J. 2002. A genealogical approach to organizational life chances: The parent-progeny transfer and Silicon Valley law firms, 1946-1996. Administrative Science Quarterly, 47: 474-506.

Pinch, T. J. \& Bijker, W. E. 1984. The social construction of facts and artefacts: Or how the sociology of science and the sociology of technology might benefit each other. Social Studies of Science, 14: 399-441.

Powell, W. W. 1988. Institutional effects on organizational structure and performance. In L. G. Zucker (Ed.), Institutional Patterns and Organizations: Culture and Environment: 115-136. Cambridge, MA: Ballinger.

Powell, W. W. 1991. Expanding the scope of institutional analysis. In W. W. Powell \& P. D. DiMaggio (Eds.), The New Institutionalism in Organizational Analysis: 183203. Chicago: University of Chicago Press.

Rao, H. 1998. Caveat Emptor: The Construction of Nonprofit Consumer Watchdog Organizations. American Journal of Sociology, 103(4): 912-961.

Rao, H., Davis, G. F., \& Ward, A. 2000. Embeddedness, social identity and mobility: Why firms leave the NASDAQ and join the New York Stock Exchange. Administrative Science Quarterly, 45(2): 268-292.

Rao, H., Morrill, C., \& Zald, M. N. 2000. Power plays: How social movements and collective action create new organizational forms. Research in Organizational Behavior, 22: 237-281. 
Rosenbloom, R. S. \& Christensen, C. M. 1994. Technological discontinuities, organizational capabilities, and strategic commitments. Industrial and Corporate Change, 3: 655-685.

Saville, D. \& Wood, G. 1991. Statistical Methods: The Geometric Approach. New York: Springer-Verlag.

Schneiberg, M. 2002. Organizational heterogeneity and the production of new forms: Politics, social movements, and mutual companies in American fire insurance. In M. Lounsbury \& M. J. Ventresca (Eds.), Research in the Sociology of Organizations, Vol. 19: 39-89. United States: JAI Press.

Schneiberg, M., King, M., \& Smith, T. 2008. Social movements and organizational form: Cooperative alternatives to corporations in the American insurance, dairy, and grain industries. American Sociological Review, 73(4): 635-667.

Schumpeter, J. A. 1934. Capitalism, Socialism, and Democracy. New York: Harper \& Row.

Schumpeter, J. A. 1939. Business Cycles. New York: McGraw-Hill.

Scott, R. 2008. Lords of the dance: Professionals as institutional agents. Organization Studies, 29(2): 219-238.

Shane, S. 2000. Prior Knowledge and the Discovery of Entrepreneurial Opportunities. Organization Science, 11(4): 448.

Sierra Club. 2000. Sierra Club Conservation Policies: Biomass Guidance. San Francisco, CA: Sierra Club. 
Simon, H. A. 1947. Administrative Behavior. New York: Macmillan.

Simonton, D. K. 1975. Sociocultural context of individual creativity: A transhistorical time-series analysis. Journal of Personality and Social Psychology, 32: 1119-1133.

Simonton, D. K. 1988. Scientific Genius: A Psychology of Science. Cambridge, England: Cambridge University Press.

Sine, W. D., Haveman, H. A., \& Tolbert, P. S. 2005. Risky Business?

Entrepreneurship in the New Independent-Power Sector. Administrative Science Quarterly, 50(2): 200-232.

Sine, W. D. \& Lee, B. H. 2009. Tilting at windmills? The environmental movement and the emergence of the U.S. wind energy sector. Administrative Science Quarterly, 54: 123-155.

Sorensen, J. B. 2007. Bureaucracy and Entrepreneurship: Workplace Effects on Entrepreneurial Entry. Administrative Science Quarterly, 52: 387-412.

Sørensen, J. B. \& Sorenson, O. 2007. Corporate demography and income inequality: Vertical and horizontal sorting as sources of regional wage dispersion. American Sociological Review, 72: 766-783.

Suchman, M. C. 1995. Managing legitimacy: Strategic and institutional approaches. Academy of Management Review, 20(3): 571-610.

Swaminathan, A. \& Wade, J. 2001. Social movement theory and the evolution of new organizational forms. In C. B. Schoonhoven \& E. Romanelli (Eds.), The Entrepreneurship Dynamic in Industry Evolution: 286-313. Palo Alto, CA: Stanford University Press. 
Tolbert, P. S., David, R. J., \& Sine, W. D. 2010. Studying choice and change: The intersection of institutional theory and entrepreneurship research. Organization Science, forthcoming.

Tolbert, P. S. \& Zucker, L. 1996. The institutionalization of institutional theory. In S. R. Clegg \& C. Hardy \& W. R. Nord (Eds.), Handbook of Organization Studies: 175190. London: Sage.

Toplyn, G. \& Maguire, W. 1991. The differential effect of noise on creative task performance. Creativity Research Journal, 4(337-347).

Tushman, M. L. \& Anderson, P. 1986. Technological Discontinuities and Organizational Environments. Administrative Science Quarterly, 31(3): 439-465.

Van Gerpen, J., Pruszko, R., Clements, D., Shanks, B., \& Knothe, G. 2006. Building a

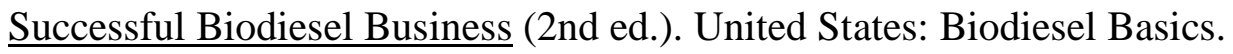

Vernet, J. 2005. An assessment of waste vegetable oil supply in Brooklyn, NY and its potential as a biodiesel feedstock. New York City: Cornell University Cooperative Extension. October 14, 2005.

Wade, J. B., Swaminathan, A., \& Saxon, M. S. 1998. Normative and Resource Flow Consequences of Local Regulations in the American Brewing Industry, 1845-1918. Administrative Science Quarterly, 43(4): 905-935.

Weber, K., Heinze, K. L., \& DeSoucey, M. 2008. Forage for thought: Mobilizing codes in the movement for grass-fed meat and dairy products. Administrative Science Quarterly, 53(3): 529-567. 
Wooldridge, J. M. 2009. Introductory econometrics: A modern approach (4th ed.). Mason, OH: South-Western Cengage Learning. 